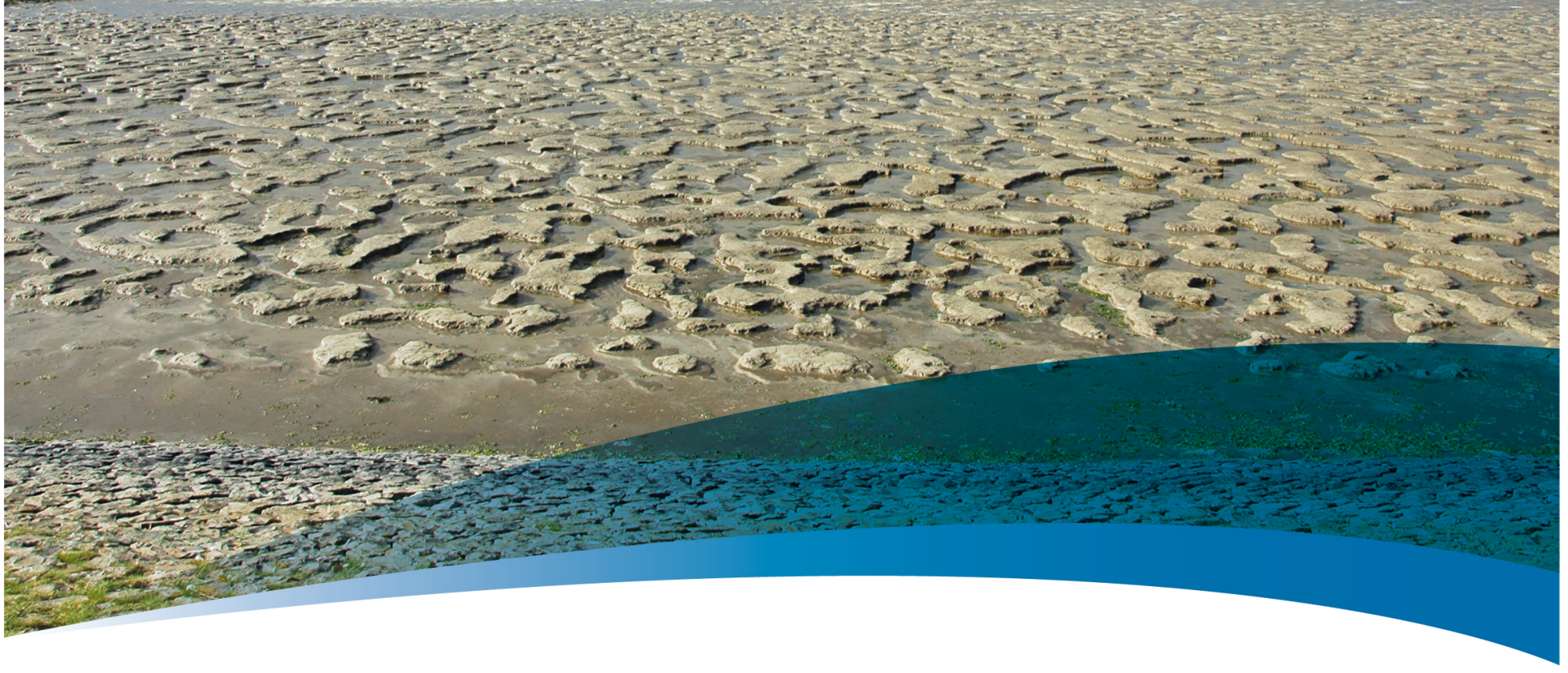

\title{
Beneficial use of dredged sediment to enhance salt marsh development by applying a 'Mud Motor': evaluation based on monitoring
}


EcoShape - Building with Nature

Project: $\quad$ Salt marsh development at Koehoal by means of a Mud Motor

Report title: Beneficial use of dredged sediment to enhance salt marsh development by applying a 'Mud Motor': evaluation based on monitoring

Report Wageningen Marine Research rapport C088/19 \& Deltares

number: $\quad 1209751$

https://doi.org/10.18174/500109

Authors: $\quad$ Martin Baptist (Wageningen Marine Research)

Julia Vroom (Deltares)

Pim Willemsen (Deltares, NIOZ, UTwente)

Marinka van Puijenbroek (Wageningen Marine Research)

Bas van Maren (Deltares)

Pim van Steijn (Deltares)

Marin van Regteren (Wageningen University)

Irene Colosimo (Delft University of Technology)

Reviewers: Kelly Elschot (Wageningen Marine Research)

Thijs van Kessel (Deltares)

Project Martin Baptist

manager:

Date: $\quad$ September 30, 2019

Data $\quad$ https://doi.org/10.4121/collection:MUD MOTOR

repository:

\begin{tabular}{llllll}
\hline Version & Date & Author(s) & Initials & Review & Initials \\
\hline 2.6 & Sept 2019 & J. Vroom & J & T. van Kessel & TVK \\
\hline final & Sept 2019 & M.J. Baptist & MS & K. Elschot & KE \\
\hline
\end{tabular}

This work was supported by the Dutch Waddenfonds under grant number WF221847

\section{Contact}

Spuiboulevard 210

3311 GR Dordrecht

+31786111099

info@ecoshape.nl

www.ecoshape.nl 


\section{Contents}

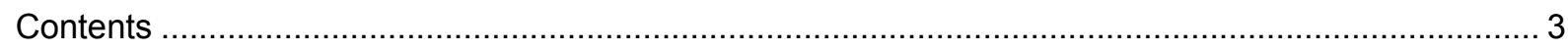

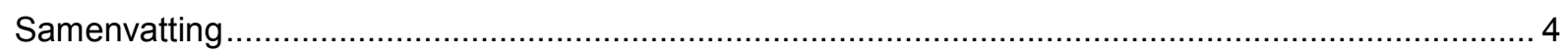

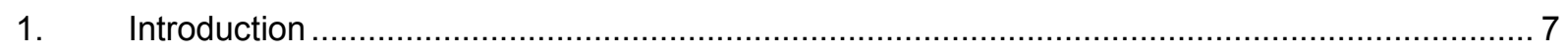

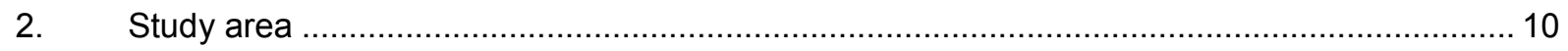

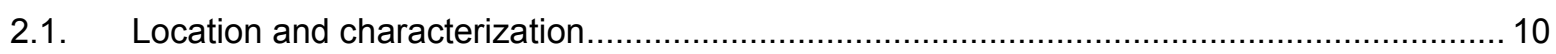

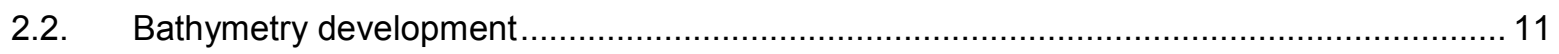

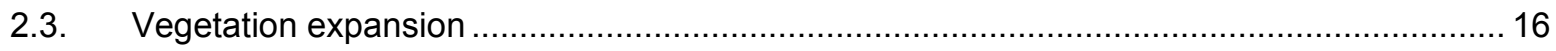

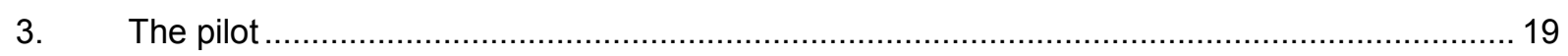

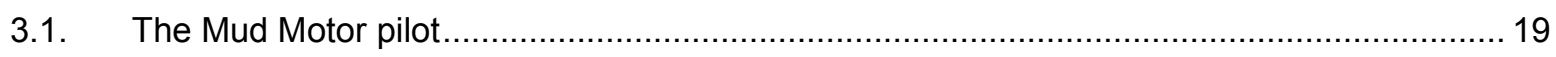

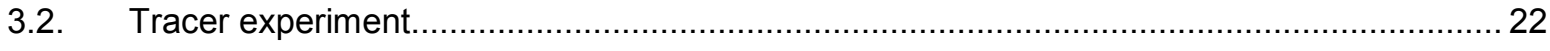

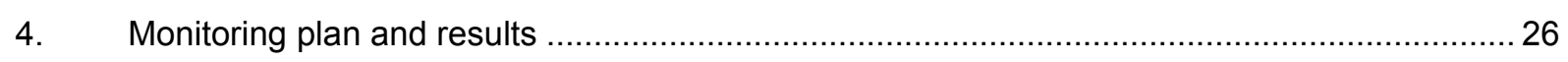

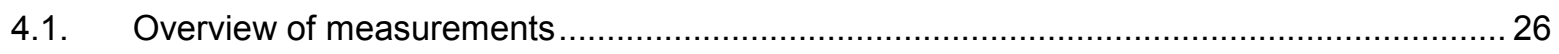

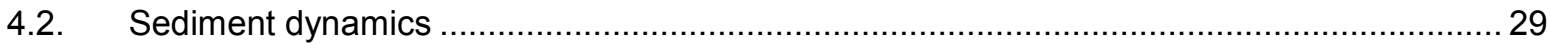

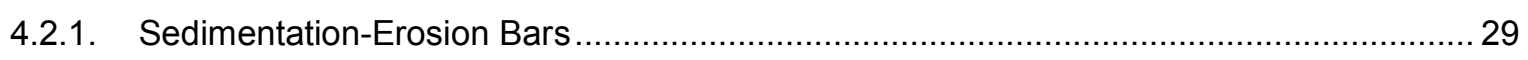

4.2.2. Surface Elevation Dynamics sensors .................................................................... 33

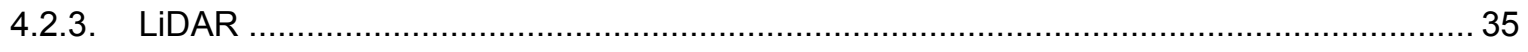

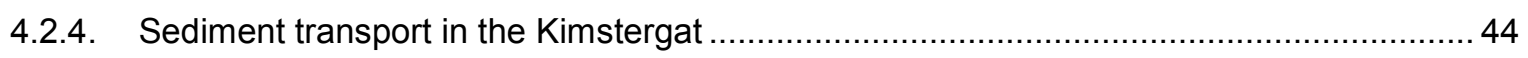

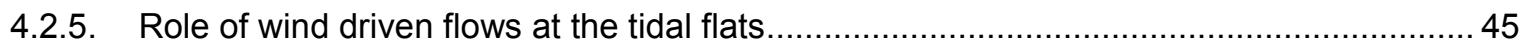

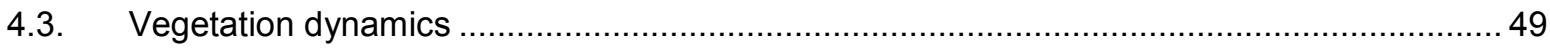

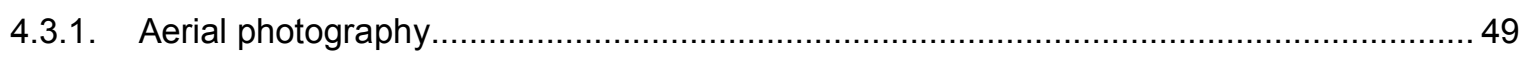

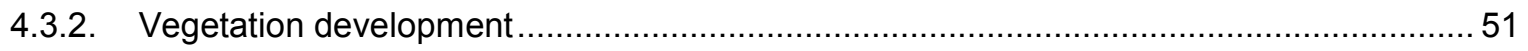

4.3.3. Establishment of pioneer species on the salt marsh edge ............................................. 56

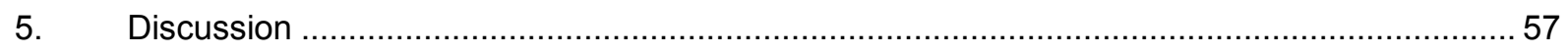

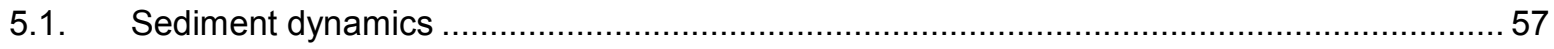

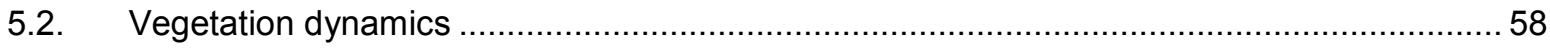

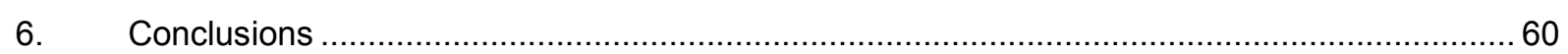

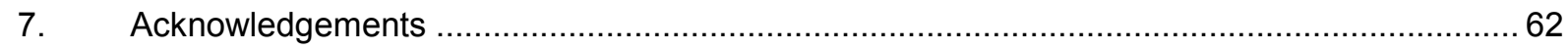

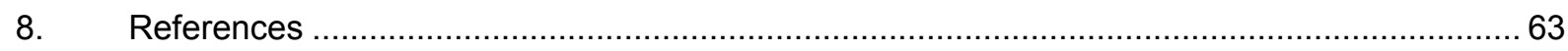




\section{Samenvatting}

\section{Introductie}

Bij de haven van Harlingen is een innovatieve methode beproefd voor hergebruik van baggerslib om de ontwikkeling van een kwelder te stimuleren: de slibmotor. Bij een slibmotor wordt baggerspecie als een semi-continue bron van sediment zo dicht mogelijk bij een kwelder verspreid om vervolgens door natuurlijke transportprocessen het sediment af te zetten voor en op de kwelder met als doel deze te laten aangroeien. De hypothese is dat door toepassing van een slibmotor de natuurlijke kweldergroei wordt versneld zonder directe verstoring van de kwelder om zodoende de natuurlijke biologische en geomorfologische kenmerken te behouden.

Dit rapport beschrijft de resultaten van het monitoringsprogramma waarmee het effect van de slibmotor op de ontwikkeling van slikken en kwelders is gevolgd.

\section{Resultaten en discussie}

De sedimentdynamiek van de slibmotor wordt beïnvloed door abiotische en biotische kenmerken. $\mathrm{Na}$ decennia-lange sedimentatie in het studiegebied als gevolg van de afsluiting van de Zuiderzee, groeit ook de kwelder van Koehoal-Westhoek sinds 1996, maar deze uitbreiding is niet lineair en is zeer waarschijnlijk gerelateerd aan de combinatie van weersomstandigheden en sedimentdynamiek. De groei was het grootst in de jaren tussen 1992 en 2005, een periode met weinig stormen en relatief veel regen. Zoals aangegeven door de ligging van de gemiddelde hoogwaterlijn, is er potentieel voor verdere kwelderuitbreiding. Het doel van de slibmotor was om de sedimenttoevoer te verhogen, om hiermee de verticale sedimentatie op de kwelder en wad te versnellen, waarna horizontale vegetatie-uitbreiding van de kwelder naar het wad volgt. Tijdens de eerste slibmotorperiode van september 2016 tot augustus 2017 vertoonden de kwelder en het wad wel verticale sedimentatie, maar nam het kwelderareaal af. In de tweede slibmotorperiode van september 2017 tot augustus 2018 ondergingen de kwelder en het wad verticale erosie, maar trad er wel horizontale uitbreiding op van de vegetatie. In tegenstelling tot onze verwachting is verticale groei van kwelder en wad dus niet direct gerelateerd aan horizontale uitbreiding van het kwelderareaal.

De lange-termijn verandering van de bodemhoogte is bepaald met sedimentatie-erosie balken (SEBs). Resultaten van de metingen toonden een relatief grote dynamiek in bodemhoogte. De sedimentatie in de referentiekwelder van Zwarte Haan liet een soortgelijke dynamiek zien als bij de kwelder tussen Koehoal en Westhoek. Een algemeen effect van de slibmotor op extra sedimentatie kon niet worden aangetoond, omdat de natuurlijke dynamiek erg groot is ten opzichte van de te verwachtten sedimentatie en vanwege de relatief korte duur van de pilot. Binnen de kwelder was de ruimtelijke variabiliteit in sedimentatie aanzienlijk. Een grotere sedimentdynamiek (erosie en sedimentatie) werd gevonden in de zuidelijke raaien dichterbij de slibmotorverspreidingslocatie in vergelijking met de noordelijke raaien. Dit zou het gevolg kunnen zijn van een andere oriëntatie van het kustprofiel ten opzichte van de dominante, zuidwestelijke windrichting. Over het algemeen was er een seizoensvariabiliteit waarbij sedimentatie plaatsvond tijdens de winter en erosie en/of consolidatie tijdens de zomer. Lagen van vloeibaar slib (soft mud) met een dikte van maximaal $10 \mathrm{~cm}$ werden elk jaar rond september afgezet, maar verdwenen weer rond maart. De belangrijkste processen die verantwoordelijk zijn voor het verdwijnen van deze sliblaag zijn hoogstwaarschijnlijk verdichting en erosie. Als de sliblaag blijft liggen, kunnen een paar opeenvolgende warme dagen leiden tot uitdroging en significante verdichting. Een hoogwater of storm kan leiden tot erosie van deze laag. Onze twee- of driemaandelijkse SEB-metingen konden geen onderscheid maken tussen de processen erosie en verdichting, maar lieten wel grote veranderingen in bodemhoogte zien.

Korte-termijn veranderingen van de bodemhoogte werden bepaald met Surface Elevation Dynamics (SED) sensoren op het wad dichtbij de dijk (d.w.z. binnen $100 \mathrm{~m}$ van de dijk). De grootte van de bodemveranderingen zijn in overeenstemming met de SEB-metingen en vertonen variaties door sedimentatie en erosie tot $10 \mathrm{~cm}$ op een tijdschaal van dagen (SEDs) tot maanden (SEBs). De plotselinge veranderingen in bodemhoogte konden worden gerelateerd aan windgedreven golven en 
verhoogde waterstanden. Stormcondities leidden tot grote bodemhoogteveranderingen, terwijl de bodem tijdens rustiger periodes geleidelijker veranderde. Dit werd duidelijk waargenomen in de verlagingen (geultjes) op het wad. Tussen periodes met abrupte veranderingen volgde de verandering van de bodemhoogte de springtij-doodtijcyclus. De verlagingen vulden zich met (vloeibaar) slib tijdens deze kalmere periodes. Een toename van de sedimentatie in verhouding tot de extra verspreidde slibmotorvolumes kon niet worden vastgesteld uit de SED-metingen.

LIDAR-metingen toonden aan dat het patroon van geulen en bulten op het wad niet gekoppeld is aan de seizoenen. De onderliggende patronen lijken persistent en hun zichtbaarheid wordt bepaald door het al dan niet opvullen met zacht slib. Hierdoor lijken de patronen in de verdichte bodem beïnvloed te worden door processen op een kortere tijdschaal (bijvoorbeeld extreme hydrodynamische gebeurtenissen zoals wind en golven), maar ze zijn het niet. De meest opvallende patronen werden waargenomen in de gebieden met een bodemniveau tussen 0,7 en $1 \mathrm{~m}+\mathrm{NAP}$, het meest bovenin het intergetijdengebied.

Metingen vanaf meetframes op het wad lieten een sterk effect van wind op transport van slib en sedimentconcentratie zien. De waarneming dat de sedimentdynamiek in het gebied van de slibmotor wordt gedomineerd door windgedreven stroming heeft belangrijke gevolgen voor de werking van de slibmotor:

1. Sediment hoeft niet rechtstreeks van de slibmotor naar de Koehoal kwelder te worden vervoerd. Het kan met de vloed worden getransporteerd naar het noordoosten, tijdelijk worden afgezet op het Terschellinger wad gelegen ten noordoosten van het Koehoal wad, en vervolgens (terug) worden vervoerd naar het Koehoal wad tijdens een noordoosten wind.

2. Er lijkt een overschot van sediment te zijn in het studiegebied, gegeven de zeer hoge sedimentconcentraties (typische pieken van 1 tot $10 \mathrm{~g} / \mathrm{l}$ ) en de sterke invloed van de windrichting op de sedimentfluxen. Het toevoegen van sediment aan een systeem met een sedimentoverschot is niet efficiënt om de sedimentatie te versterken, omdat het sedimentaanbod hierin niet de limiterende factor is.

3. Het sedimentoverschot suggereert dat de belangrijkste beperking voor sedimentatie de juiste omstandigheid is waarbij slib (semi-)permanent wordt vastgelegd. Slib kan gedurende een periode van weken sedimenteren, maar daarna nog steeds gemakkelijk worden geërodeerd onder redelijk normale hydrodynamische omstandigheden. Dit heeft een negatief effect op de werking van de slibmotor. Voorwaarden voor een meer permanente afzetting van sediment kunnen zijn een juiste volgordelijkheid van geschikte windomstandigheden, en/of verdichting door uitdroging, en/of vastlegging door vegetatieontwikkeling.

Hoewel verticale sedimentatie belangrijk is voor een kwelder om gelijke tred te houden met de zeespiegelstijging, wordt het totale oppervlak van een kwelder bepaald door de horizontale uitbreiding/terugtrekking van de vegetatie. Aangezien de meest voorkomende pioniersoorten éénjarigen zijn, bepalen de jaarlijkse weersomstandigheden en de jaarlijkse sedimentdynamiek in grote mate de grootte van de pionierzone. Factoren die bepalend zijn voor de kiemkracht en de groei van pionierplanten zijn overstromingsfrequentie, temperatuur, neerslag en sedimentdynamiek. Sedimentafzetting of erosie kan zaden en kleine planten begraven of uithollen. In 2017 nam het kwelderareaal af met 3 ha. De sedimentafzetting was dat jaar hoog $(4 \mathrm{~cm})$ en vooral hoog op het wad $(5 \mathrm{~cm})$. Een hypothese is dat zaden of jonge kiemplanten zijn begraven onder een te dikke laag sediment en dit niet hebben overleefd. De sedimentdynamiek was in 2017 behoorlijk groot, met grote hoeveelheden afgezet sediment wat later weer is geërodeerd of geconsolideerd. Dit wijst erop dat een hoge sedimentdynamiek niet bevorderlijk is voor vegetatie-uitbreiding. Het aanbod van slib en de capaciteit om het slib vast te leggen (door consolidatie, uitdroging, vegetatie) moeten goed met elkaar overeenkomen voor een optimale kwelderontwikkeling. Een te klein aanbod van slib leidt op den duur tot erosie, een te groot aanbod van slib beklijft niet (slib spoelt snel weer weg) en kan zelfs leiden tot minder vegetatieontwikkeling door begraving van zaden.

\section{Conclusies}

De slibmotor was bedoeld om kwelderuitbreiding van de kwelder Koehoal-Westhoek te stimuleren. Het verwachte effect was gebaseerd op een conceptueel model voor afzetting en erosie in de getijdengeul 
Kimstergat met direct transport van fijn slib naar de nabijgelegen wadplaten en kwelders. Belangrijke bevindingen uit het monitoringsprogramma zijn dat het transport van slib in het studiegebied sterk wordt beïnvloed door windkracht en -richting en dat het slib slechts tijdelijk op het wad en de kwelders blijft, afhankelijk van specifieke windomstandigheden leidend tot erosieve gebeurtenissen op korte tijdschalen. Het belang van de aanvoer van extra slib ten opzichte van de lokale herverdeling van al in de omgeving aanwezig slib is minder groot dan initieel verwacht. De sedimentdynamiek op de kwelder Koehoal-Westhoek is vergelijkbaar met de dynamiek op de referentiekwelder Zwarte Haan, ondanks de slibmotor. Een toename van de sedimentdynamiek in relatie tot de verspreide slibmotorvolumes kon niet met zekerheid worden vastgesteld. Het kwelderareaal nam zelfs in oppervlakte af in de eerste slibmotorwinter maar groeide in de tweede slibmotorwinter. Bij het evalueren van de resultaten van de slibmotor concluderen we dat er meer hydrodynamische invloed van golven en stroming op erosie is dan van tevoren voorzien. We veronderstellen nu dat het verspreidde slib tijdelijk werd opgeslagen in ons studiegebied, maar vervolgens weer is geërodeerd.

Naast slibsedimentatie spelen ook biotische processen een rol in het uitbreiden van kwelderareaal. Experimenten waarbij zeekraalzaad werd uitgestrooid vóór de kwelderrand hebben bevestigd dat belangrijke condities zoals hoogte en overstromingsduur geschikt waren voor vegetatieontwikkeling en dus voor kwelderuitbreiding. Echter, de belangrijkste beperking voor de natuurlijke vestiging van vegetatie in de overgangszone tussen kwelder en wad bleek de beschikbaarheid van levensvatbare zeekraalzaden. Het is plausibel dat niet een tekort aan sediment, maar een tekort aan levensvatbaar zeekraalzaad de limiterende factor was voor kwelderuitbreiding in het Slibmotor project. 


\section{Introduction}

World trade is growing, and over $80 \%$ of the volume of global trade is transported via sea (PIANC 2011). Coastal ports handle seaborne trade and these ports need to maintain navigable depth to stay operational. Many ports are situated in deltas or regions with large loads of fine sediments. Consequently, many ports worldwide suffer from substantial volumes of maintenance dredging (IADC 2015). Ports may additionally enhance the import of marine sediment e.g. by channel deepening, thereby worsening the siltation problems.

Dredged fine sediments are often considered unsuitable for re-use. However, as already written in Finding 29 of the 1985 book on Dredging Coastal Ports "Dredged sediment should be regarded as a resource rather than a waste" (National Research Council 1985). Sediments, including fine sediments, can be a valuable resource, and even more so given relative sea level rise and sediment starvation due to engineering works (Meade \& Moody 2010). Authorities worldwide are therefore vigilant for initiatives involving the beneficial use of dredged material. Habitat development, beach nourishment, aquaculture, parks and recreation, agriculture, waste landfill, and construction uses are examples of beneficial use of dredged material from a 1987 engineer manual of the USACE (U.S. Army Corps of Engineers 1987), all based on experience from as early as the 1960s and 1970s. A later USACE summary report by (Brandon \& Price 2007) on guidance and best practices for determining suitability of dredged material for beneficial uses distinguishes three broad categories of beneficial use, i.e. engineered uses, agricultural and product uses, and environmental enhancements. In the latter category Yozzo et al. (2004) give seven examples for habitat restoration/creation using dredged material: creation of artificial reefs and shoals, oyster reef restoration, bathymetric recontouring, creation/restoration and enhancement of intertidal marshes and mudflats, filling in dead-end canals and basins, creation of bird/wildlife islands and remediation/creation of upland habitats.

Coastal habitats such as tidal areas and salt marshes are ranked among the most important habitats regarding ecosystem services (Temmerman et al. 2013). One of these services is coastal protection, in addition to water infiltration and regulation, nurturing fisheries and providing livelihoods to communities from shellfisheries to tourist industries. Tidal flats and salt marshes form a vital part of coastal safety worldwide (Kirwan \& Megonigal 2013; Temmerman et al. 2013; Spalding et al. 2014). Moreover, these coastal habitats are invaluable for conserving biodiversity (Dijkema et al. 1984).

Already by 1987, more than 130 freshwater and saltwater marshes have been purposely created using dredged material substrates in U.S. waterways. Marsh development techniques are, since decades, sufficiently advanced to design and construct productive systems with a high degree of confidence (U.S. Army Corps of Engineers 1987). All case studies on restoration and enhancement of intertidal marshes and mudflats known to us, involve the placement of dredged sediment directly onto the desired location, with the correct elevation, orientation, shape and size, and sometimes include artificial propagation of marsh plants. By far, most examples are known from the USA, in particular from the Mississippi River delta, such as studies on spray disposal (Cahoon \& Cowan 1988; Ford et al. 1999) and salt marsh raising with dredged material (Delaune et al. 1990; Mendelssohn \& Kuhn 2003; Graham \& Mendelssohn 2013; Tong et al. 2013).

Data of three decades of experience in the USA summarised by (Streever 2000) suggest that dredged material marshes do not replace all of the functions of natural marshes. In most dredged material marshes Smooth cordgrass Spartina alterniflora successfully established and the marshes provided suitable habitats for birds, but these cannot be the only two attributes to determine the similarity between natural and dredged material marshes. When comparing a number of parameters including soil, biological and geomorphological characteristics, (Streever 2000) found that some attributes of natural and dredged material marshes are reasonably similar while others are clearly different, such as for aboveground and belowground biomass of $S$. alterniflora, organic carbon in sediments, polychaete densities, and crustacean densities. A recent British study on saltmarsh restoration by managed 
realignment confirms that these saltmarshes also lack the topographic diversity found in natural habitats (Lawrence et al. 2018). (Streever 2000) calls upon application of innovative research approaches to advance the field of marsh development using dredged material. In particular, (Shafer \& Streever 2000) suggest to develop methods to mimic natural marsh geomorphology.

Since 2007, private parties, government organisations, research institutes, universities and NGOs joined their forces in a Dutch foundation called EcoShape. They carried out the "Building with Nature" innovation programme (BwN) from 2008 to 2012 and are currently engaged in a second phase BwN innovation programme running to 2020. The programme aims to test and develop a new design philosophy in hydraulic engineering that utilizes the forces of nature thereby strengthening nature, economy and society. The USACE's Engineering with Nature and the Working with Nature programme of the World Association for Waterborne Transport Infrastructure (PIANC) coincided with EcoShape's programme. The BwN sub-programme Ports of the Wadden Sea is studying innovative approaches to sediment management in the Wadden Sea. The Dutch Wadden Sea has eleven small and four mediumsized ports, in total having an annual dredged volume of more than five million $\mathrm{m}^{3}$. The Building with Nature approach facilitates the proactive utilization and/or provision of ecosystem services as part of the engineering solution to port dredging. Four concepts are or will be tested in real-life case studies, i.e. 1) optimising dredging strategies, 2) enhancing salt marsh development, 3) creating estuarine gradients, and 4) optimising flow patterns (Van Eekelen et al. 2016; Baptist et al. 2017) all in conjunction with extensive field campaigns to closely monitor the success of the pilots.

One Building with Nature concept to be tested in a pilot study is using fine-grained dredged sediments as a resource to enhance salt marsh development. Bringing mud in the currents that feed a salt marsh is expected to accelerate vertical and lateral marsh-growth, while maintaining the desired gradients that are associated with the growth of perennial vegetation. Many conditions need to be met before salt marshes can expand, such as a sufficient transport capacity of mud and limited erosion stress (Hu et al. 2015; Poppema et al. 2019), surface elevation, wave energy, sediment supply and drainage (Dijkema 1983; Dijkema et al. 1990). Perennial halophytic vegetation typical for marshes, such as Spartina anglica and Puccinellia maritima, can establish near mean high water (MHW) (Dijkema et al., 1990). Once perennial vegetation has established, it will stimulate accretion, reduce erosion and geomorphological patterns in the marsh platform start to develop by positive feedback processes (Langlois et al. 2003; Van Wesenbeeck et al. 2008; Schwarz et al. 2015; Vandenbruwaene et al. 2015). Salt marsh vegetation lowers the hydrodynamic load from currents and waves, thereby increasing the sedimentation rates on the marsh (Neumeier \& Amos 2006; Leonardi et al. 2018). Root systems stabilize the soil which reduces erosion potential (Allen 1989). As a result, a vegetated saltmarsh is likely to continue accumulating sediment and develop a natural marsh biology and geomorphology.

We tested an innovative approach to beneficially re-use dredged sediment to enhance salt marsh development: deposit the dredged sediment as a semi-continuous source of sediment in a tidal channel and allow natural processes to disperse the sediment to nearby salt marshes (see Figure 1-1). This method was named Mud Motor. Differing from the Sand Motor or Sand Engine, in which a large volume of sand was deposited at once (Aarninkhof et al. 2012; Stive et al. 2013), the Mud Motor served as a semi-continuous source of sediment. While applying the Mud Motor, dredged material was supposed to supplement and accelerate natural marsh growth without direct disturbance and thereby maintaining natural marsh biology and geomorphology. The potential economic and ecological benefits were threefold, a reduced necessity for dredging, increased and sustainable ecosystem based coastal protection, and conserving valuable habitats for marsh-specific flora and fauna.

The goal of this report is to describe the monitoring and research programme to assess the effect of the Mud Motor on the evolution of mud flats and salt marshes. The report gives an extensive overview of the results of the monitoring programme and extends on the scientific paper by Baptist et al. (2019). 


\section{The Mud motor EcoShape $\overbrace{\text { waddenfonds }}$}

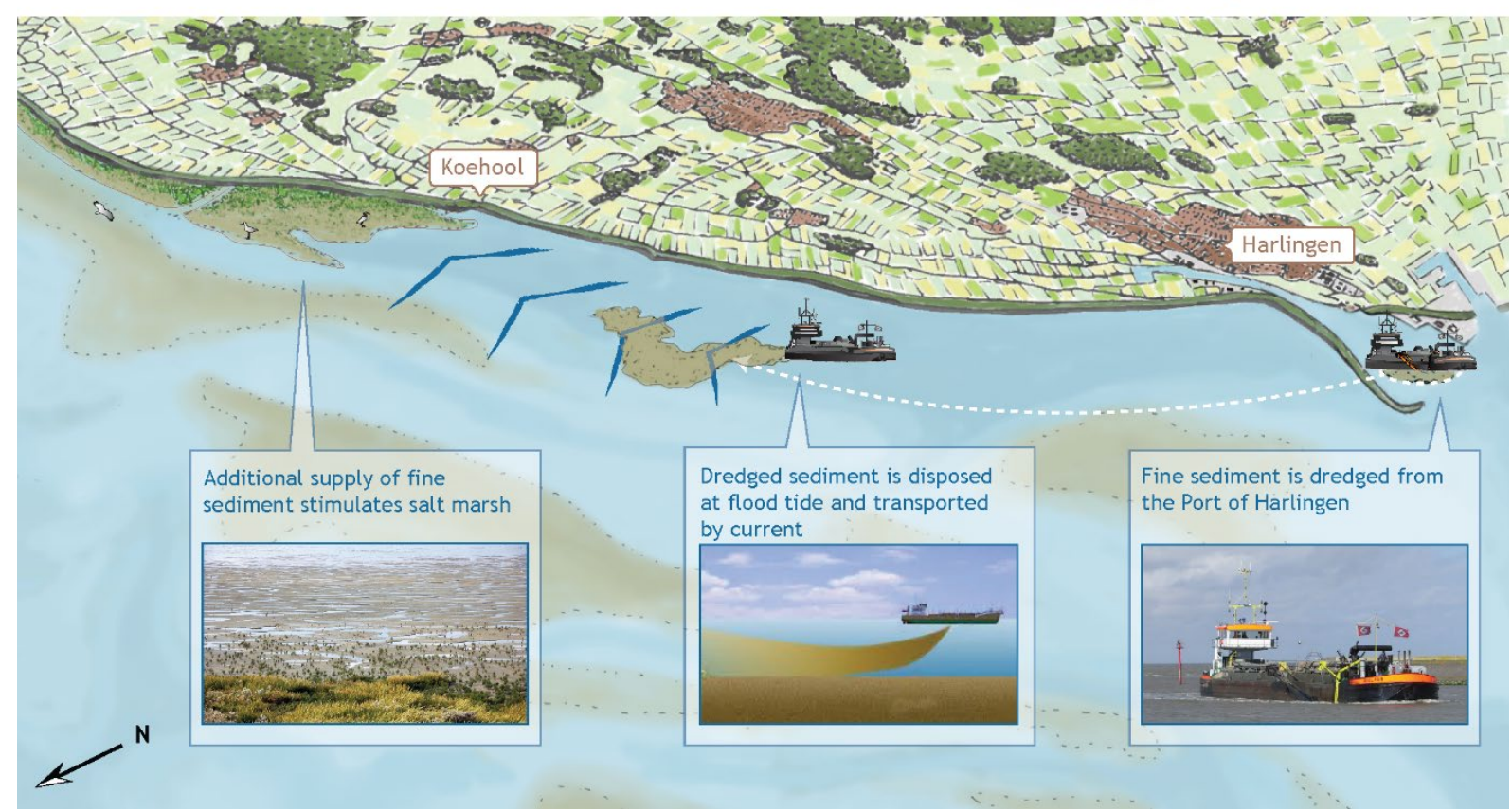

Figure 1-1. The principle of the Mud Motor approach. 


\section{Study area}

\subsection{Location and characterization}

The study site is the Dutch Wadden Sea at the province Fryslân (Figure 2-1). The main study area consists of the port of Harlingen, the Kimstergat tidal channel and the salt marshes at the northeast end of the Kimstergat. The Kimstergat is part of the Vliestroom, which is a large tidal channel that originates between the back barrier islands Vlieland and Terschelling. The targeted salt marsh for the Mud Motor lies between the villages Koehoal and Westhoek and the reference salt marsh is located near the village Zwarte Haan.

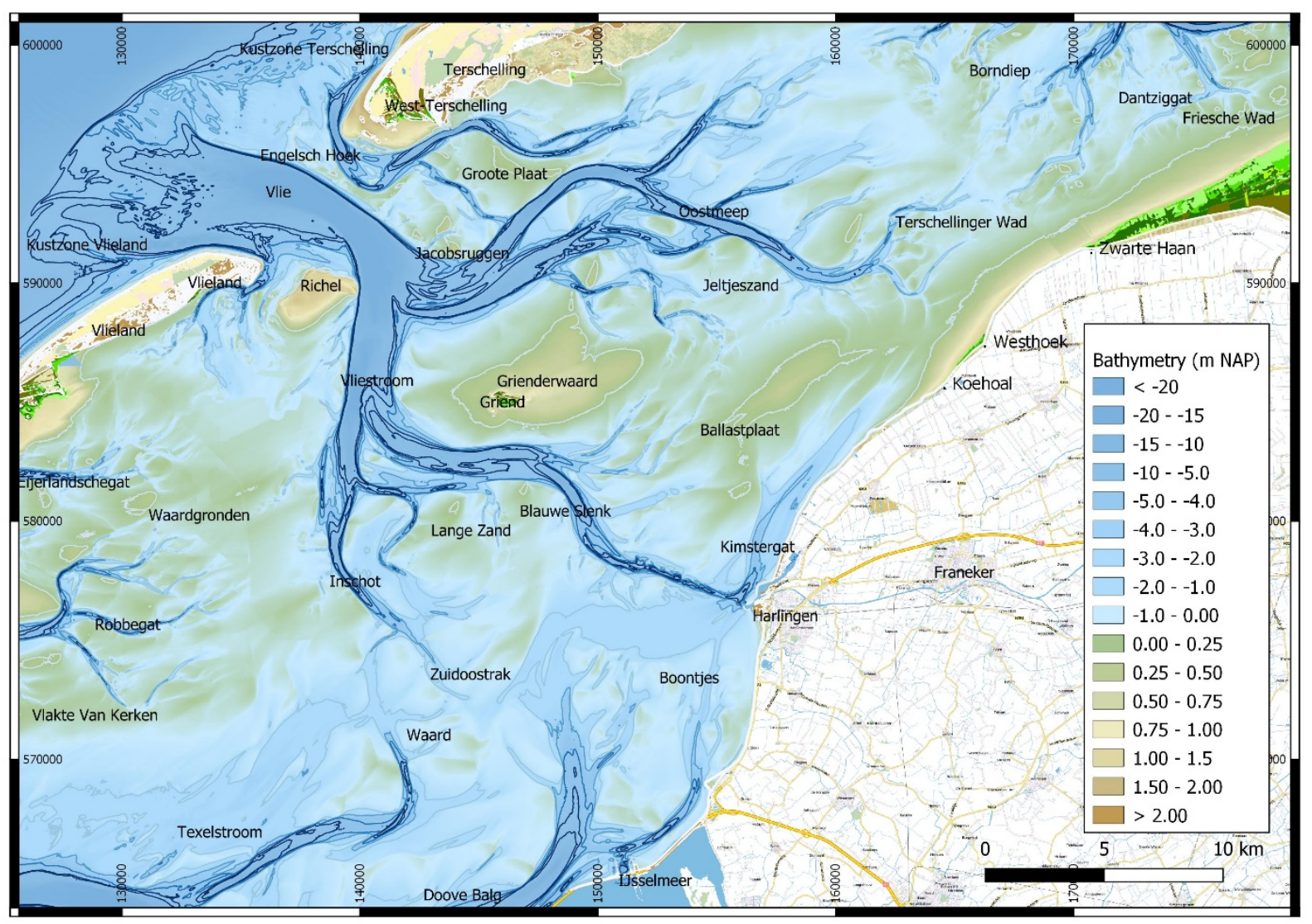

Figure 2-1. Map with names of intertidal flats, channels and salt marsh location in the area of interest. Bathymetry from 2010. The Mud Motor salt marsh is situated between Koehoal and Westhoek, the control salt marsh is situated at Zwarte Haan (in the north east corner of the map). Bright green colour (not in the colour map) indicates vegetation.

The intertidal area in front of Koehoal and Westhoek is characterised by very muddy, very gently sloping tidal flats (Figure 2-2a). The flats are generally characterised by a pattern of hummocks and hollows (Figure 2-2e and f). However, those patterns were not always visible (Figure 2-2d). In the southern end of the study area, there is a narrow fringe of salt marsh (Figure 2-2c), in the inclination of the dike near Westhoek, the salt marsh is wider. The entire area is bordered by a dike with small groins (Figure 2-2b). 

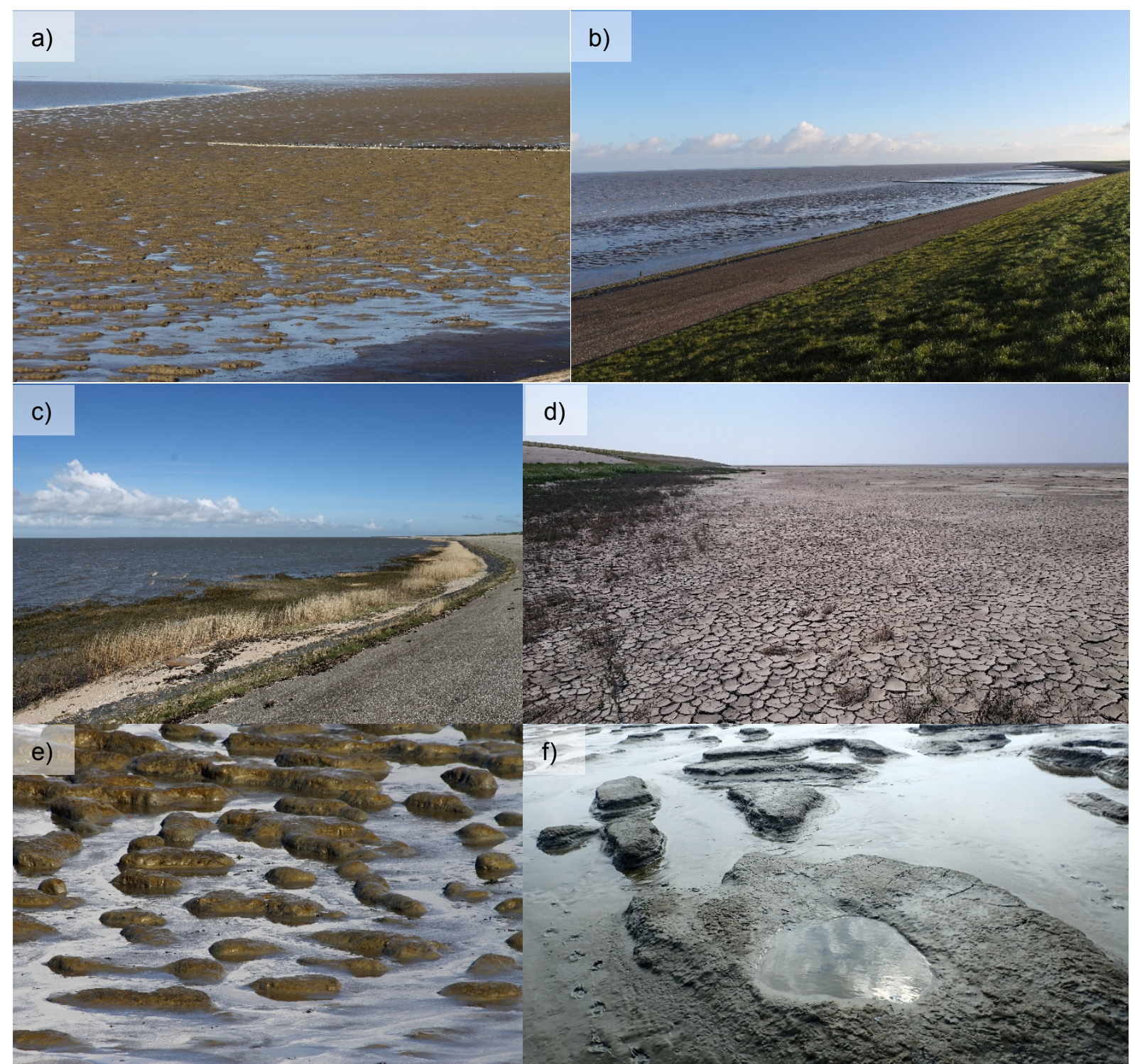

Figure 2-2. Photos from the study site. a) Sloping tidal flat with hummocks and hollows, with Kimstergat channel on the left and a groin. b) Series of groins and part of the dike in the south of the study area. c) Narrow fringe of salt marsh during high water level. d) Cracks in the flats due to drying. e) and f) Hummocks and hollows.

\subsection{Bathymetry development}

To put the development of the project area into perspective, it is relevant to have insights in the longterm morphological changes. The oldest detailed and digitally available bathymetric maps of the area from Rijkswaterstaat date from 1926. So the first data was collected just before closure of the Zuiderzee by the Afsluitdijk, which had a large impact on the Western Wadden Sea (e.g. Elias, 2006). Historical bathymetrical maps between 1926 and 2016 are shown in Figure 2-3. Clear morphological changes were observed in between 1926 and 2016 (Figure 2-4 historical bed level change in meter per year for equal comparison). The Kimstergat channel has decreased in length (black arrow in Figure 2-3), while the intertidal area near Koehoal has expanded (red arrow in Figure 2-3). Sedimentation in front of Koehoal took place since 1926, with a clear sedimentation zone along the coastline between 1971 and 1975 and a decrease in sedimentation rates since the end of the nineties. The $0 \mathrm{~m}$ NAP contour line in the subplot of Figure 2-5 shows a seaward migration of this contour and hence the expansion of the intertidal area above $0 \mathrm{~m}$ NAP in westward direction. In 2016, a large part of the area is just around the 0 m NAP level, giving a 'scattered' contour line (Figure 2-4). 
Note that the erosion-sedimentation patterns between 1992 and 1998 and 1998 and 2003 show some odd behaviour, such as an alternating erosion and sedimentation pattern at the intertidal area near Koehoal in consecutive maps, which is questionable. Also the bathymetry in 1998 contains an erroneous area in the middle of the subplot, consequently appearing in the sedimentation-erosion maps.

The Kimstergat channel has not only become shorter in length but also narrower and slightly deeper, given sedimentation bands at the west side of the channel and erosion in the centre of the channel in some of the erosion/sedimentation maps. This is confirmed by the $-2 \mathrm{~m}$ and $-3 \mathrm{~m}$ NAP contour subplots in Figure 2-5, showing a narrowing of the Kimstergat channel. The $-1 \mathrm{~m}$ and $-2 \mathrm{~m}$ NAP contour also show that the Kimstergat channel used to be following more or less the contour of the coastline. Over time the channel has become straighter and has developed a north-eastern tip that is located further from the coastline. The $-3 \mathrm{~m}$ and $-4 \mathrm{~m}$ NAP contour subplots show how the Oostmeep channel has retreated its south-west branch and expanded in north-eastern direction. The decrease in width and length of the Kimstergat channel and the expansion of the Oostmeep channel is probably a result of the closure of the Zuiderzee in 1932. Due to the closure, the Inschot channel, which was feeding the Zuiderzee, has decreased in importance. In the meantime, the Oostmeep channel has expanded.

The $0 \mathrm{~m}$ NAP contour line subplot also clearly shows a north-eastward expansion of the Ballastplaat, and also its southern end has been elongating and migrating in eastward direction. We see a similar migration at the Grienderwaard and Jetjeszand, meaning that morphological changes take place over a larger area. The Ballastplaat is bordering the west side of the Kimstergat channel and hence influencing wave dynamics and the morphological development of the Kimstergat channel.

Figure 2-6 shows the total sedimentation and erosion of the period between 1926 and 2016 over a larger area. The figure shows that the total sedimentation at the intertidal area near Koehoal amounts 2 to 3 meters. This figure also shows the erosion in the Kimstergat channel and the sedimentation at its west side. The control plot for the salt marsh measurements, at Zwarte Haan (near x-coordinate $170 \mathrm{~km}$ ) also shows long-term sedimentation, but smaller in magnitude, around $1 \mathrm{~m}$. 


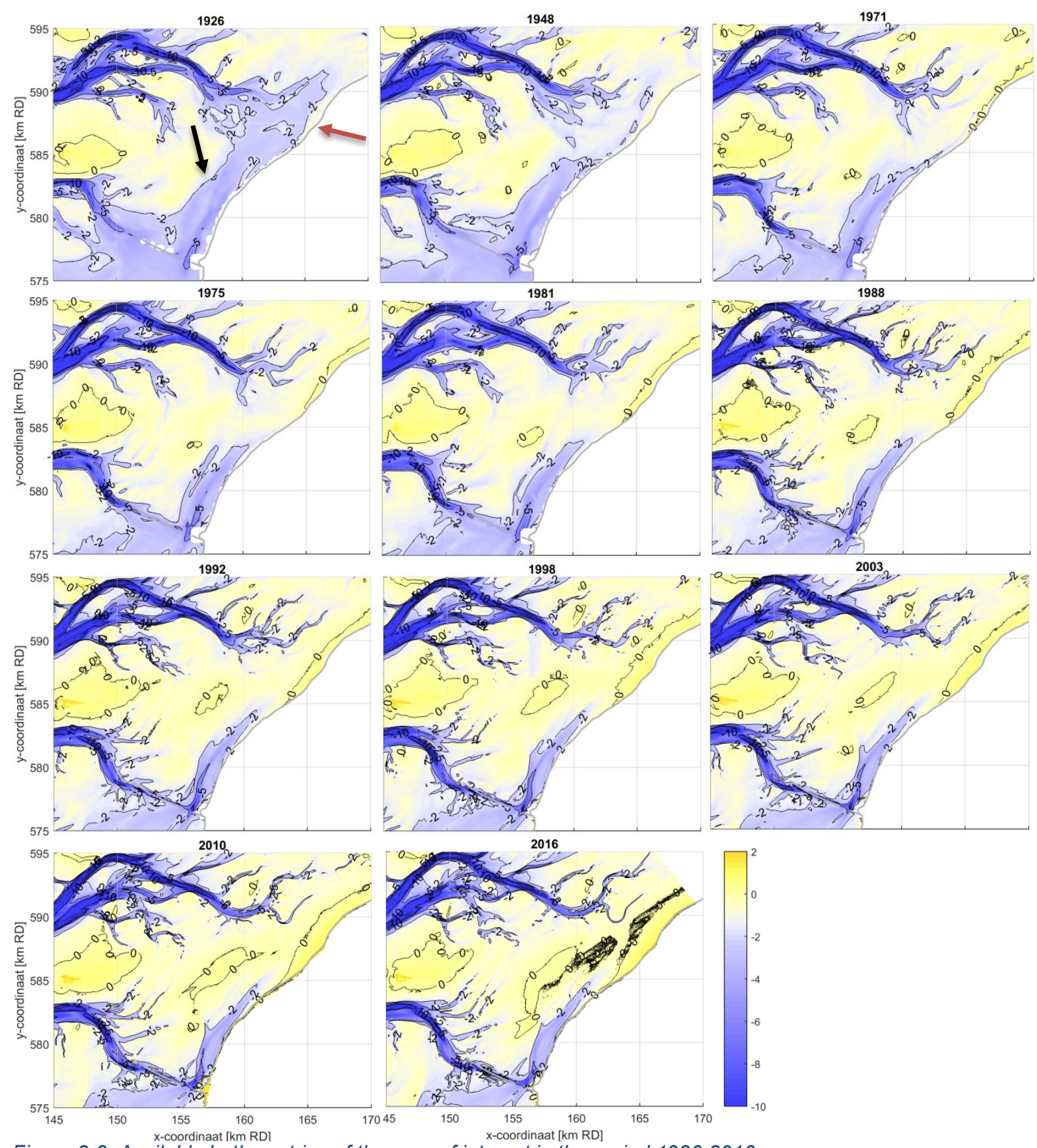

Figure 2-3. Available bathymetries of the area of interest in the period 1926-2016. 

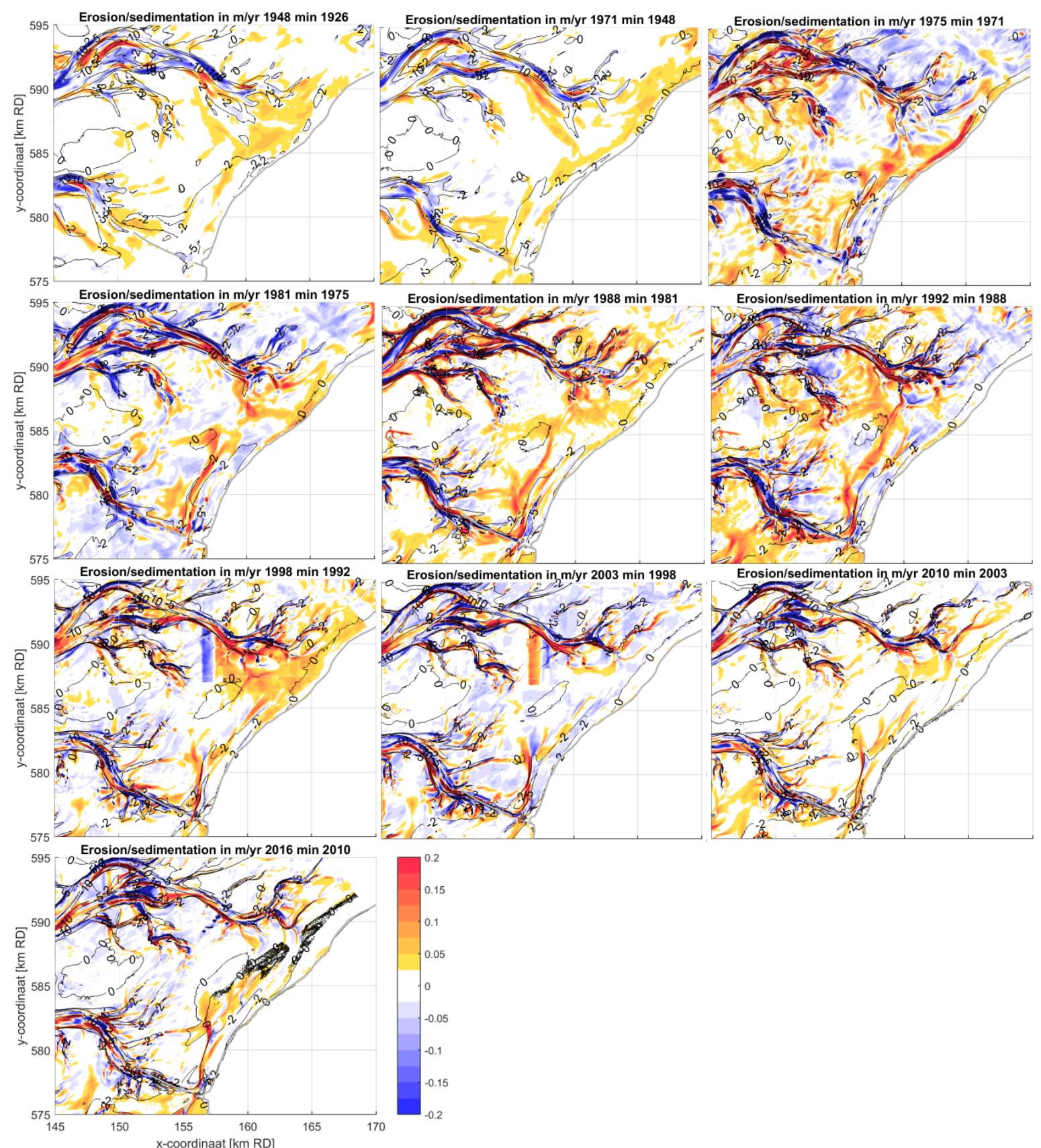

Figure 2-4. Erosion and sedimentation pattern in meter per year. 

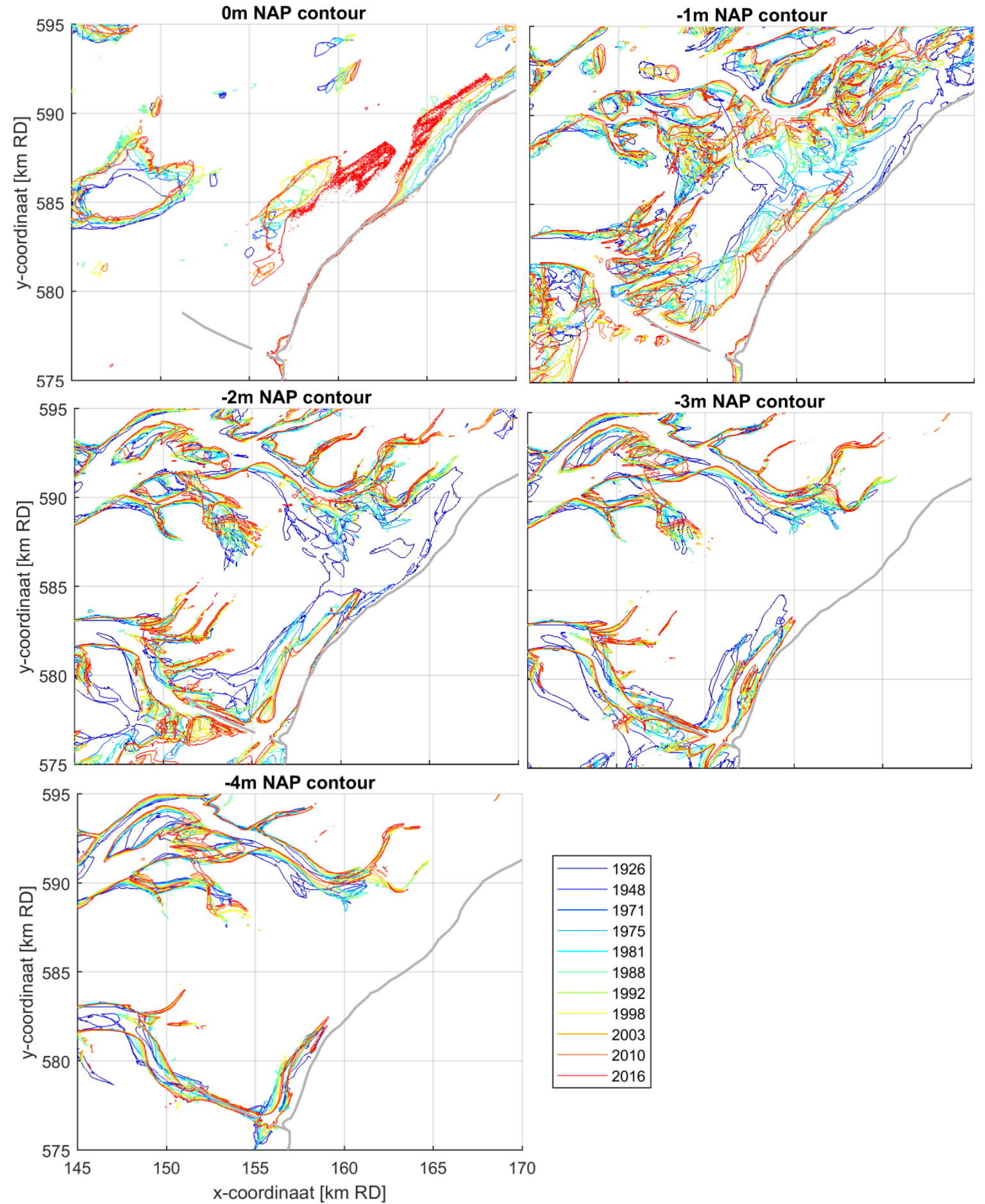

Figure 2-5. Contour lines of the bathymetry in different years (colours, see legend). 


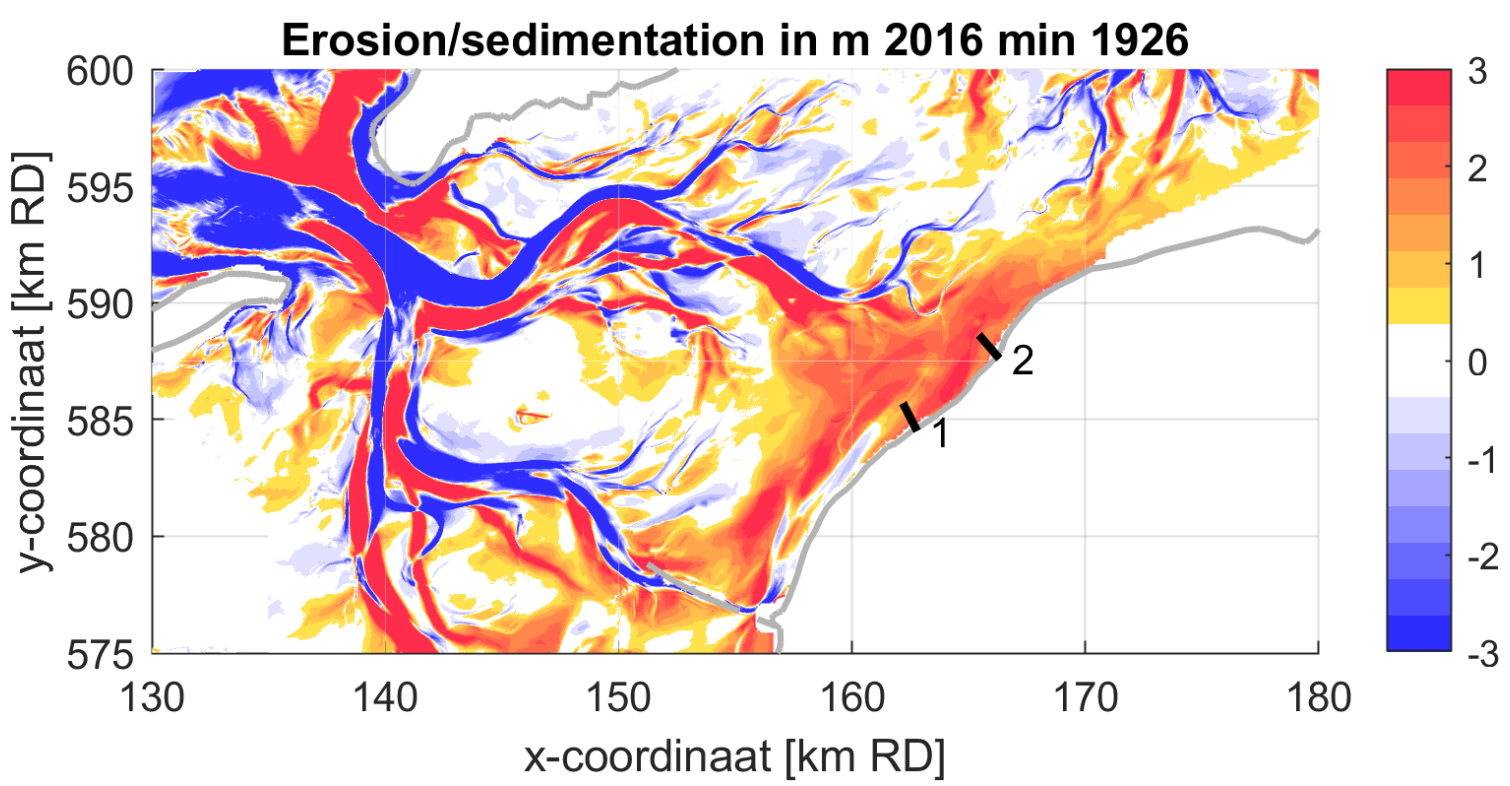

Figure 2-6. Total erosion (blue) and sedimentation (red) in [m] over the period 1926 to 2016 over the study area. The historic bed levels of the two black transects are visualised in Figure 2-7.

Figure 2-7 shows the bed level accretion of two representative transects at Koehoal (Transect 1 , unvegetated) and Westhoek (Transect 2, vegetated). At the north-eastern side, Transect 2, the bed level increased to heights above Mean High Water (MHW). Such conditions provide possibilities for pioneer vegetation establishment and germination (Dijkema et al. 1990) and have resulted in salt marsh formation and subsequent rise of the bed level to $1.5 \mathrm{~m}+\mathrm{NAP}$. At the south-western side near Koehoal a similar height has not (yet) been reached, which might explain the lack of vegetation development. Note that both transects show a decrease in vertical sedimentation rate in recent years (bed level of 2010 and 2016 almost overlap), implying that the large sedimentation to adapt to the new hydrodynamics after closure of the Zuider Sea has diminished.
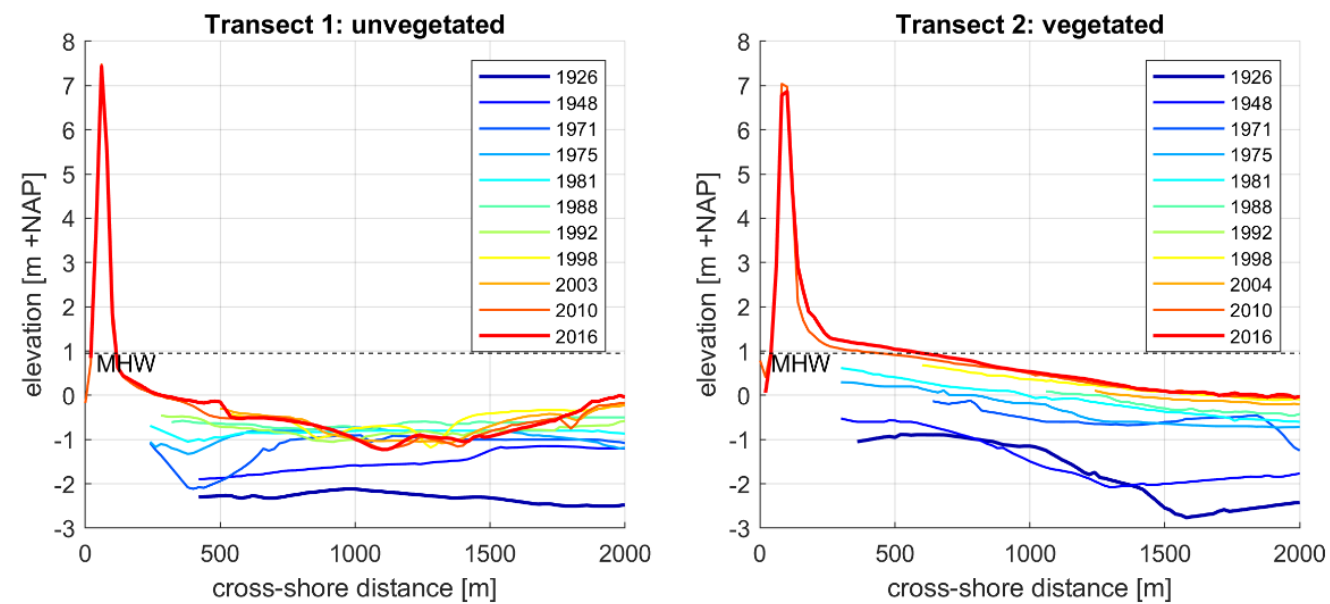

Figure 2-7. Profile evolution of an unvegetated transect (Koehoal) and a vegetated transect (Westhoek) where the absolute bed level is shown relative to Dutch Ordnance Level NAP. Location of the transects is indicated in Figure $2-6$.

\subsection{Vegetation expansion}

Aerial photographs were used to determine vegetation expansion over a longer time period. Aerial photographs were available for the following years: 1983, 1992, 1996, 2000, 2003, 2005, 2010, 2013 and 2015. The resolution of the aerial photographs between $1983-2015$ was between $0.25-1 \mathrm{~m}$, from 
these photographs the extent of the salt-marsh vegetation at the Mud motor site was manually determined.

Lateral salt-marsh growth was determined from the historical aerial photographs, and this showed that the salt-marsh surface area increased over the past two decades (Figure 2-8). This might be explained by the historic trend of accretion from 1926 onwards (see cross-section 2 in Figure 2-7). Only the last two decades was the elevation of the area high enough for vegetation establishment. Salt-marsh growth started in 1996 in the Westhoek corner. The middle part of the salt marsh grew between 1996 and 2005, after which stabilisation occurred. At the edges of the area salt marsh development started much later, around 2010 (

Figure 2-9). For the middle part a new period of growth took place between 2010 and 2015, after which the surface area stabilized again. Vegetation can occur $40-50 \mathrm{~cm}$ below mean high water line (Balke et al. 2016), however this depends on the abiotic conditions of the mudflat. In the Netherlands Wadden Sea the lower boundary is estimated at $20-40 \mathrm{~cm}$ below mean high water (Bakker et al. 2002). A conservative proxy for the boundary of the pioneer vegetation is the Mean High Water line at $0.95 \mathrm{~m}$ + NAP (Grasmeijer, 2016). The contour lines of the +0.95 m elevation show that the mudflat has sufficient elevation for vegetation establishment (Figure 2-8). The observation that vegetation expansion occurred in some but not all years is most likely caused by differences in weather conditions and sediment dynamics, that together may determine the Window of Opportunity for pioneer plants to establish $(\mathrm{Hu}$, Van Belzen, et al. 2015).

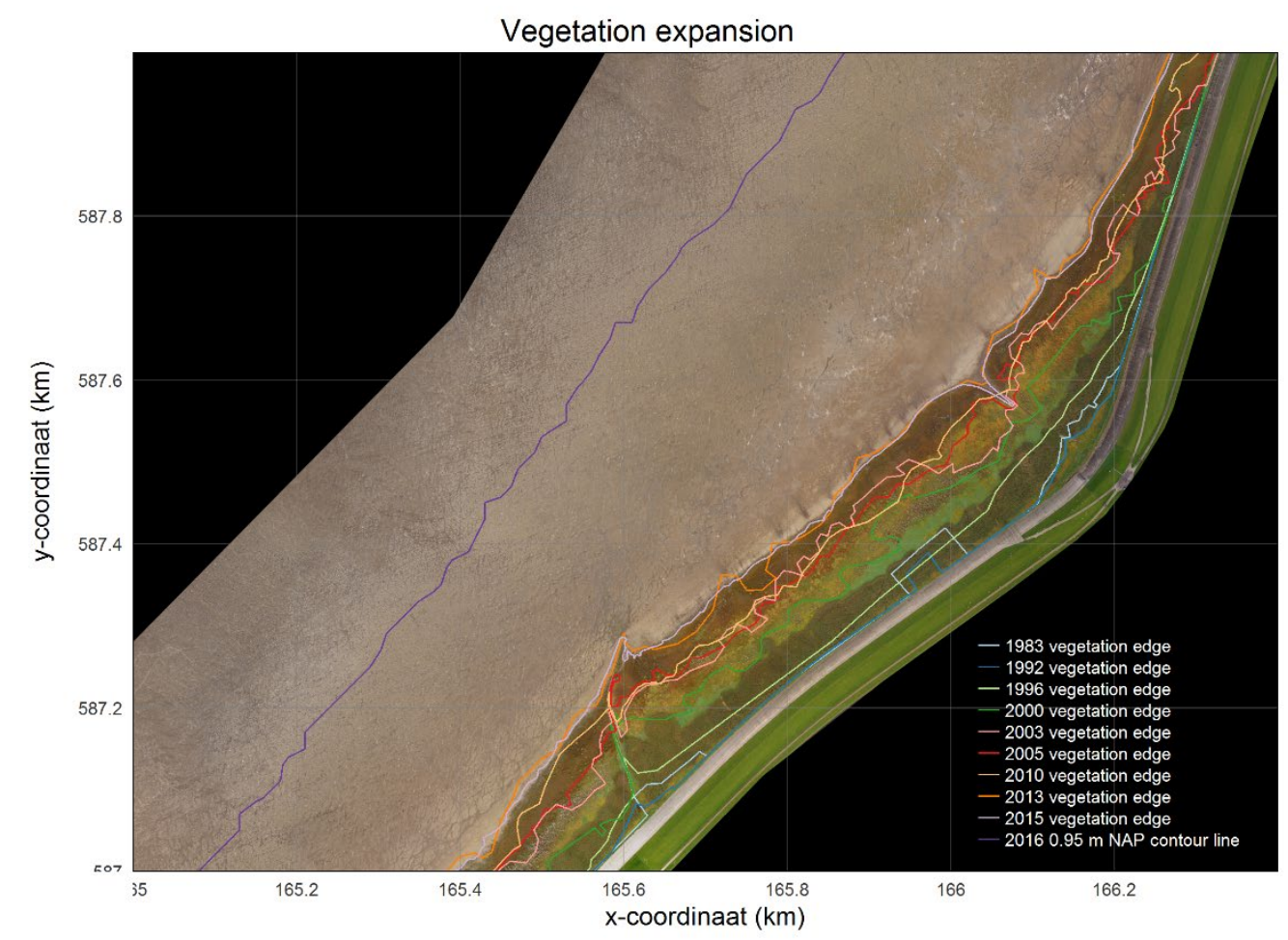

Figure 2-8. Salt marsh extent over the years 1983 - 2015 and the 0.95 m NAP contour line in 2016. The contour line indicates the potential area in which the salt marsh can expand. The aerial photograph is from 2015.

The expansion of the salt marsh initially started in the middle of our study area,

Figure 2-9. At the south-western and north-eastern boundaries of the study site the salt marsh expanded years later compared to the middle part, this is most likely because the middle part is more sheltered and therefore has also accreted more, making its elevation more suitable for vegetation establishment. 


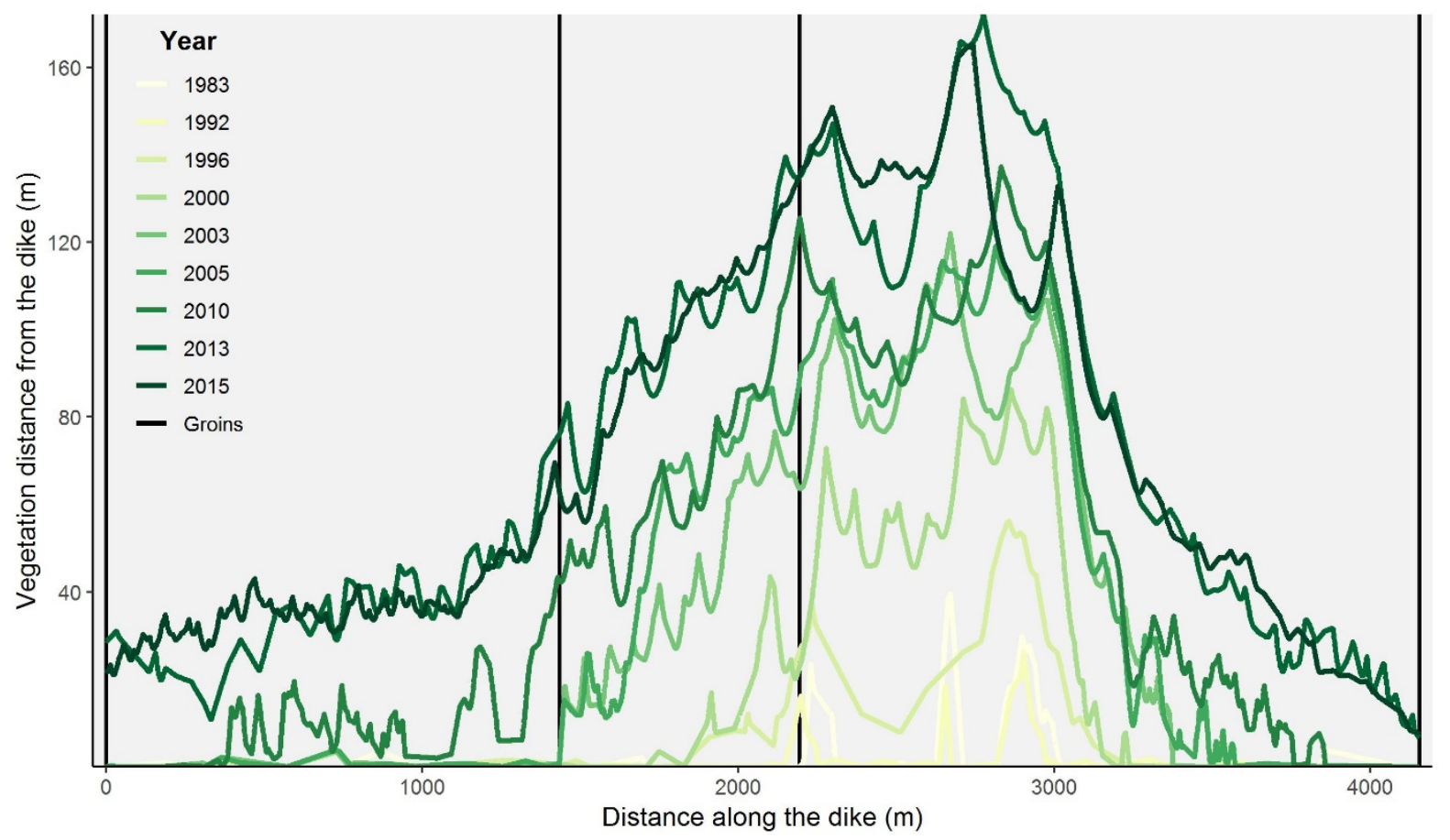

Figure 2-9. Distance of the vegetation edge from the dike $(m)$ for 1983-2015 along the Mud Motor site from southwest to northeast. The black lines indicate the groynes. 


\section{The pilot}

\subsection{The Mud Motor pillot}

The Mud Motor pilot is a change in the disposal strategy of sediment dredged at the Port of Harlingen. Unlike the Sand Motor where a large volume of sand was placed at once and thus replacing frequent nourishments, in the Mud Motor approach a (semi-)continuous disposal of dredged sediment to a new location is tested (the Mud Motor location, see Figure 3-3). In the pilot, the regular maintenance dredging operations of the Port of Harlingen with a small $604 \mathrm{~m}^{3}$ Trailing Suction Hopper Dredger (TSHD, de 'Adelaar' of the company De Boer Dredging) continued, but the disposal strategy was adapted. The boundary conditions of the pilot (budget, physical circumstances in the field, practical limitations of the hopper, and the permit) allowed only for partial change of the disposal strategy, hence also the old disposal locations were still used.

The average maintenance volume of dredged sediment from the port of Harlingen is around 1.3 million $\mathrm{m}^{3}$. The volume of dredged sediment varied over the years. The volume of dredge material is markedly lower in 2017 and 2018 compared to preceding years (Figure 3-1). This might be an effect of the Mud Motor, however, the natural variation in dredged volumes is also large, compare for instance 2012 and 2016. Normally the dredged sediment is deposited in either the Kimstergat or Pollendam location. In 2016 and 2017, as part of the pilot, dredged sediment was also deposited at the Mud Motor dumping location.
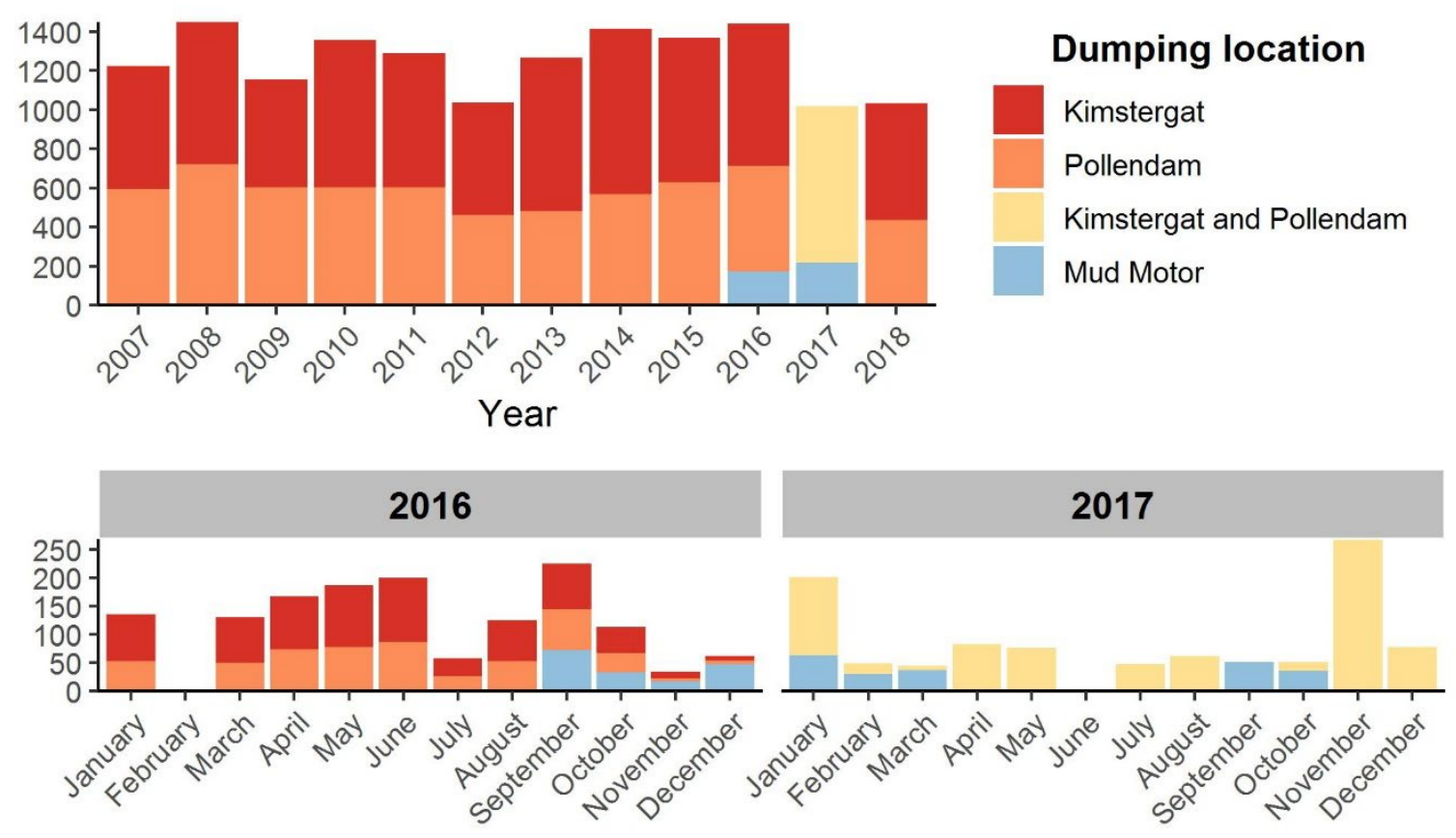

Month

Figure 3-1. The volume of disposed sediment in the years $2007-2018$, per disposal location, in $1000 \mathrm{~m}^{3}$. For the Mud Motor years 2016 and 2017, the volume of dredged sediment is shown per month. For 2017 only total dredged sediment that was deposited is known, but not how much was deposited in either Kimstergat or Pollendam.

The most promising disposal location was identified using a small-scale numerical model to mimic tidal flow conditions and taking into account the draught of the hopper (Vroom 2015). Disposal locations where based on vessel draught (the water needs to be sufficiently deep for the hopper to navigate, and the alongshore and parallel distance to Koehoal: the closer to Koehoal in the alongshore distance (e.g. 
the bleu disposal location in Figure 3-2), the larger the cross-shore direction (because of the water depth).

An important conclusion from this numerical assessment was that not only the shore parallel distance to the project area was important, but also the cross-shore distance between the disposal location and the shoreline/dike. As a result, sediment released close to the shore but relatively far away in the alongshore direction (the 'red' and 'green' locations in Figure 3-2) is more effective in nourishing the Koehoal mudflat than sediment released at the landward limit of the channel. This is caused by the orientation of the Kimstergat channel and the orientation of the shoreline, the latter is deflecting in northeast direction, away from the channel. Therefore, a disposal location was chosen relatively close to the dike (but relatively far from Koehoal in the alongshore direction). Sediment is disposed at the relatively shallow 'red' location during high water, and at the deeper 'green' location during low water. In Figure 3-3, showing the final disposal location, this was translated in MM_HW high water disposal site, MM_LW low water disposal site and MM_MW for the disposal with intermediate water levels, in order to guarantee the minimum navigation depth. The high tide site is furthest away from the Port of Harlingen and due to the shallow water depth only available closely before or after high tide, before tidal flow reverses.

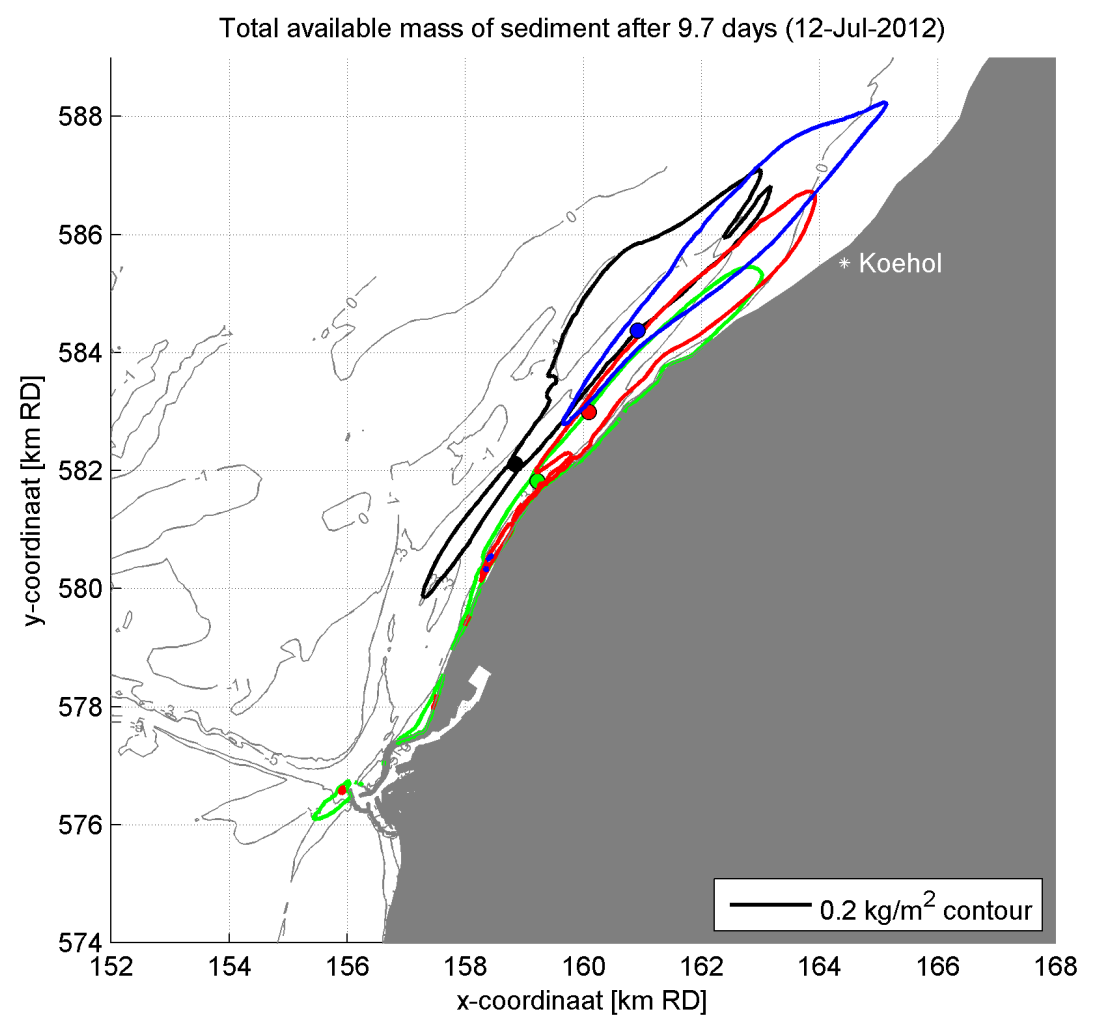

Figure 3-2. Dispersal of sediments from four release locations black, green, red and blue, computed with a numerical sediment transport model.

The disposal scheme was further refined based on the sailing distance, dredge cycle times, tidal water level predictions and daylight windows. Disposal was planned only during flood tides, i.e. when flow is directed towards the salt marsh target area. Also, because of biological activity, disposal at the Mud Motor location was only permitted between September and March. An analysis of the co-occurrence of flood flows and daylight hours revealed that in December and January there was not enough time for mud disposal of the required volumes. A change request for the permit was granted to extend the working hours to between 07:00 $\mathrm{h}$ and 19:00 h, when sunrise and sunset were within this interval. Taking all boundary conditions into account, a maximum dredge volume of $300,000 \mathrm{~m}^{3}$ could be disposed over one autumn and winter season (Grasmeijer 2016). This is roughly $1 / 3$ of the total amount of sediment dredged at the port of Harlingen. The new disposal strategy therefore includes the old disposal locations ( $\mathrm{K} 1$ and $\mathrm{K} 2$ in Figure 3-3) and the new Mud motor (MM) disposal location. Location K1 is used during flood tide, and has a much shorter sailing distance than the new location. Location $\mathrm{K} 2$ is used during 
ebb tide. The MM disposal location was chosen based on its water depth at low water (LW), mid water (MW) and high water (HW), to guarantee accessibility by the dredger. Disposal of dredged sediment from the hopper took place through bottom doors.

Table 3-1 shows the disposal volumes as realised at the new disposal location during the Mud Motor pilot. Dredging operations were carried out daily. The average cycle time for the Mud Motor disposals was around 1:45 h. The realised number of mud disposals was dependent on appropriate high tides inside the available time window, and on other factors such as weather conditions and technical issues. An average number of approximately 22 mud disposals per operating week, with a weekly volume of 13,288 $\mathrm{m}^{3}$ was achieved. In the first Mud Motor season from 1 September 2016 to 31 March 2017 in total $300,188 \mathrm{~m}^{3}$ of dredged sediment was disposed at the Mud Motor (MM) disposal sites. In the same period another 433,672 $\mathrm{m}^{3}$ was disposed at the K1 and K2 sites, Table 3-1. In the second Mud Motor season, from 1 September 2017 to 1 December 2017 a total of $170,328 \mathrm{~m}^{3}$ was disposed at the MM disposal site and another $201,780 \mathrm{~m}^{3}$ at the $\mathrm{K} 1$ and $\mathrm{K} 2$ disposal sites.

Table 3-1. Mud Motor disposed volumes per week. $N$ is number of disposals, Volume is disposed volume $\left(\mathrm{m}^{3}\right)$ and Cumulative is cumulative volume $\left(\mathrm{m}^{3}\right)$ for Mud Motor Season 1 and Mud Motor Season 2.

\begin{tabular}{|c|c|c|c|c|c|c|c|}
\hline Season 1 & $\mathrm{~N}$ & Volume & Cumulative & Season 2 & $\mathrm{~N}$ & Volume & Cumulative \\
\hline week 2016-36 & 28 & 16912 & 16912 & week 2017-36 & 23 & 13892 & 13892 \\
\hline week 2016-37 & 34 & 20536 & 37448 & week 2017-37 & 24 & 14496 & 28388 \\
\hline week 2016-38 & 29 & 17516 & 54964 & week 2017-38 & 22 & 13288 & 41676 \\
\hline week 2016-39 & 29 & 17516 & 72480 & week 2017-39 & 16 & 9664 & 51340 \\
\hline week 2016-40 & 16 & 9664 & 82144 & week 2017-40 & 22 & 13288 & 64628 \\
\hline week 2016-41 & 14 & 8456 & 90600 & week 2017-41 & 16 & 9664 & 74292 \\
\hline week 2016-42 & 14 & 8456 & 99056 & week 2017-42 & 21 & 12684 & 86976 \\
\hline week 2016-48 & 30 & 18120 & 117176 & week 2017-43 & 27 & 16308 & 103284 \\
\hline week 2016-49 & 25 & 15100 & 132276 & week 2017-44 & 16 & 9664 & 112948 \\
\hline week 2016-50 & 31 & 18724 & 151000 & week 2017-45 & 28 & 16912 & 129860 \\
\hline week 2016-51 & 22 & 13288 & 164288 & week 2017-46 & 30 & 18120 & 147980 \\
\hline week 2017-01 & 27 & 16308 & 180596 & week 2017-47 & 29 & 17516 & 165496 \\
\hline week 2017-02 & 19 & 11476 & 192072 & week 2017-48 & 8 & 4832 & 170328 \\
\hline week 2017-03 & 28 & 16912 & 208984 & & & & \\
\hline week 2017-04 & 31 & 18724 & 227708 & & & & \\
\hline week 2017-05 & 29 & 17516 & 245224 & & & & \\
\hline week 2017-06 & 27 & 16308 & 261532 & & & & \\
\hline week 2017-07 & 3 & 1812 & 263344 & & & & \\
\hline week 2017-11 & 16 & 9664 & 273008 & & & & \\
\hline week 2017-12 & 30 & 18120 & 291128 & & & & \\
\hline week 2017-13 & 15 & 9060 & 300188 & & & & \\
\hline
\end{tabular}




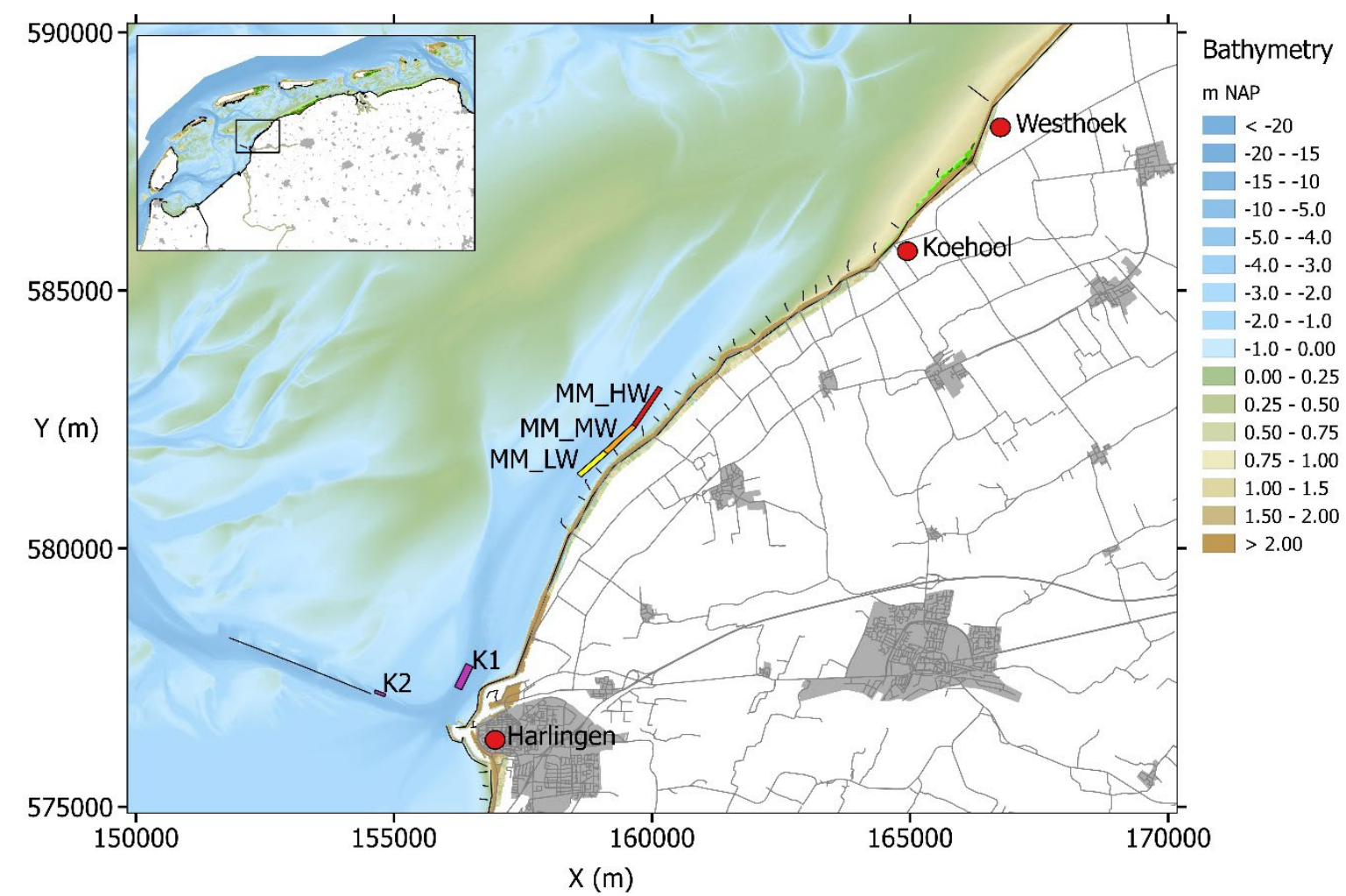

Figure 3-3. Bathymetric map of the study area, with dredged sediment disposal locations K1, K2, MM_LW, MM MW and MM_HW. Coordinates shown in Dutch grid EPSG:28992.

\subsection{Tracer experiment}

Prior to changing the original dredging strategy of the port, a tracer experiment was carried out in the field. This tracer experiment existed of release of $100 \mathrm{~kg}$ dry weight of very fine tracer particles (equivalent with $\sim 4 \times 10^{14}$ tracer particles) from the trailing suction hopper dredger, completely mixed in the hopper with dredged material from the port of Harlingen. By mixing the tracer with dredged sediments in the hopper, we assume the tracer particles to be encapsulated in flocs formed by the natural sediments, and thereby behave similarly. In addition, the tracer particle size was chosen such, that it was similar to the particle size of the sediment from the port of Harlingen, i.e. having a $D_{50}$ of $\sim 10$ $\mu \mathrm{m}$. Subsequently, the intertidal area at the area of interest was sampled by foot at low tide and from a small ship during high tide. As the tracer particles are not visible with the naked eye, soil samples were collected at several time intervals after tracer release and shipped to the laboratory for determination of its tracer content.

The tracer experiment had multiple aims. With the tracer experiment, the effectiveness of the Mud Motor concept could be assessed for the first time. This was done by collecting a large number of bed samples, determining the amount of tracer particles per sample and extrapolating this amount to the entire area of interest, i.e. the tidal flats and salt marshes near Koehoal. Then the amount of tracer particles that were brought to the target area could be compared to the amount of tracer particles that were released from the hopper, as an estimation of the effectiveness of the disposal location.

Not only the effectiveness of the new disposal location was of interest, also a comparison with the effectiveness of one of the old locations is very relevant. It gives information on the amount of sediment arriving at the target location from each of the two locations, and hence the benefit of bringing sediment much closer to the target area. The original disposal location K1 was chosen for comparison (and not $\mathrm{K} 2$ ) because this location is also used during flood tide, hence having similar tidal conditions, but with a larger distance to the salt marsh target area. Locations of the disposal sites are shown in Figure 3-3. 
The distinction between the two locations was made by using two different coloured tracer particles. At each location $100 \mathrm{~kg}$ dry weight tracer particles was released.

The evolution of sedimentation patterns over time was assessed by carrying out multiple sampling campaigns (one, two, and 4-5 weeks after release of the tracer). This gives an indication of the transportation time of the tracer from the disposal location to the target area. By using a large amount of sampling locations $(\sim 100)$, not only the amount but also the variability of the sedimentation within the area of interest could be assessed.

The conditions in the field were relevant for interpreting the results of the tracer experiment (Figure 3-4). During tracer release at the new disposal location, it was high water in Harlingen and the wind was blowing from a west-south-west direction with a speed of $10 \mathrm{~m} / \mathrm{s}$. One day later, during rising tide, tracers were released at location $\mathrm{K} 1$, at much lower wind speeds of $2 \mathrm{~m} / \mathrm{s}$ from the north. In the period between tracer release and sampling of the target area some water level set-up took place, with wind directed from the southwest to northwest quadrant. These conditions promote sediment transport towards the target area. Figure 3-5 shows the phase lag between water level at Harlingen and flow velocity at the MM disposal location, as computed by the simple numerical model (without wind) used for selecting the optimal disposal location. The hydrodynamics are not hindcasted from the tracer experiment period, but are representative for the phase lag between water levels and flow velocities. It shows that flow reversal at the MM disposal location typically occurs $\sim 1$ hour after high water in Harlingen and flow reversal occurs $\sim 30 \mathrm{~min}$. after low water at location $\mathrm{K} 1$. This means that the tracer released at both locations have been done at optimal circumstances: at location MM the water level needed to be high in order to bring the particles as close as possible to the target area and for one hour the flow was still in the right direction (tidal excursion length during this hour is estimated to be 500-1000 m). At location K1 the tracers were released just after flow reversal, promoting transport towards the target area.

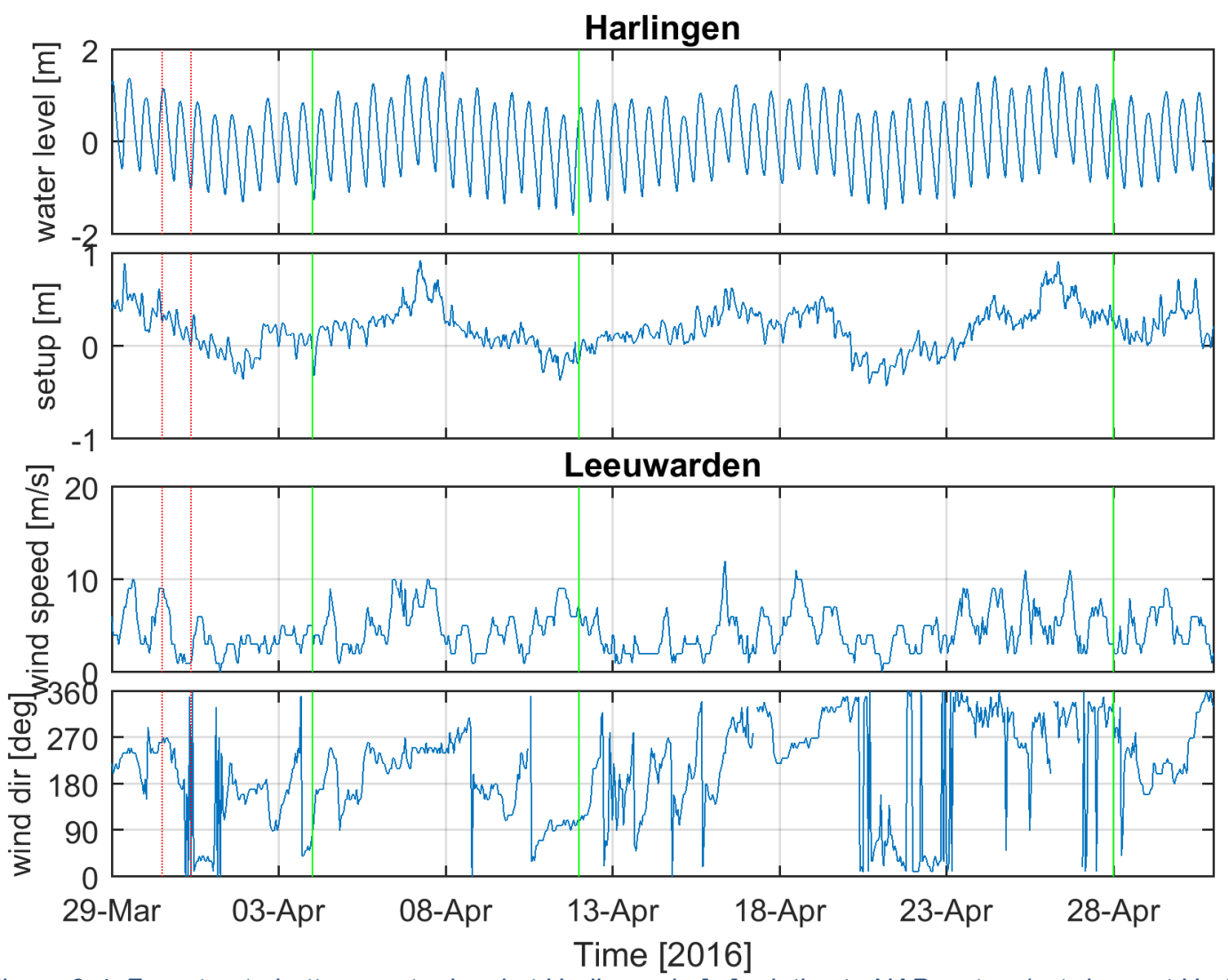

Figure 3-4. From top to bottom: water level at Harlingen in [m] relative to NAP, set-up/set-down at Harlingen due to wind in [m], wind speed at Leeuwarden, wind direction at Leeuwarden. Water level data from Rijkswaterstaat, wind data from KNMI. Vertical red lines indicate release and vertical green line indicate sample collection campaigns. 


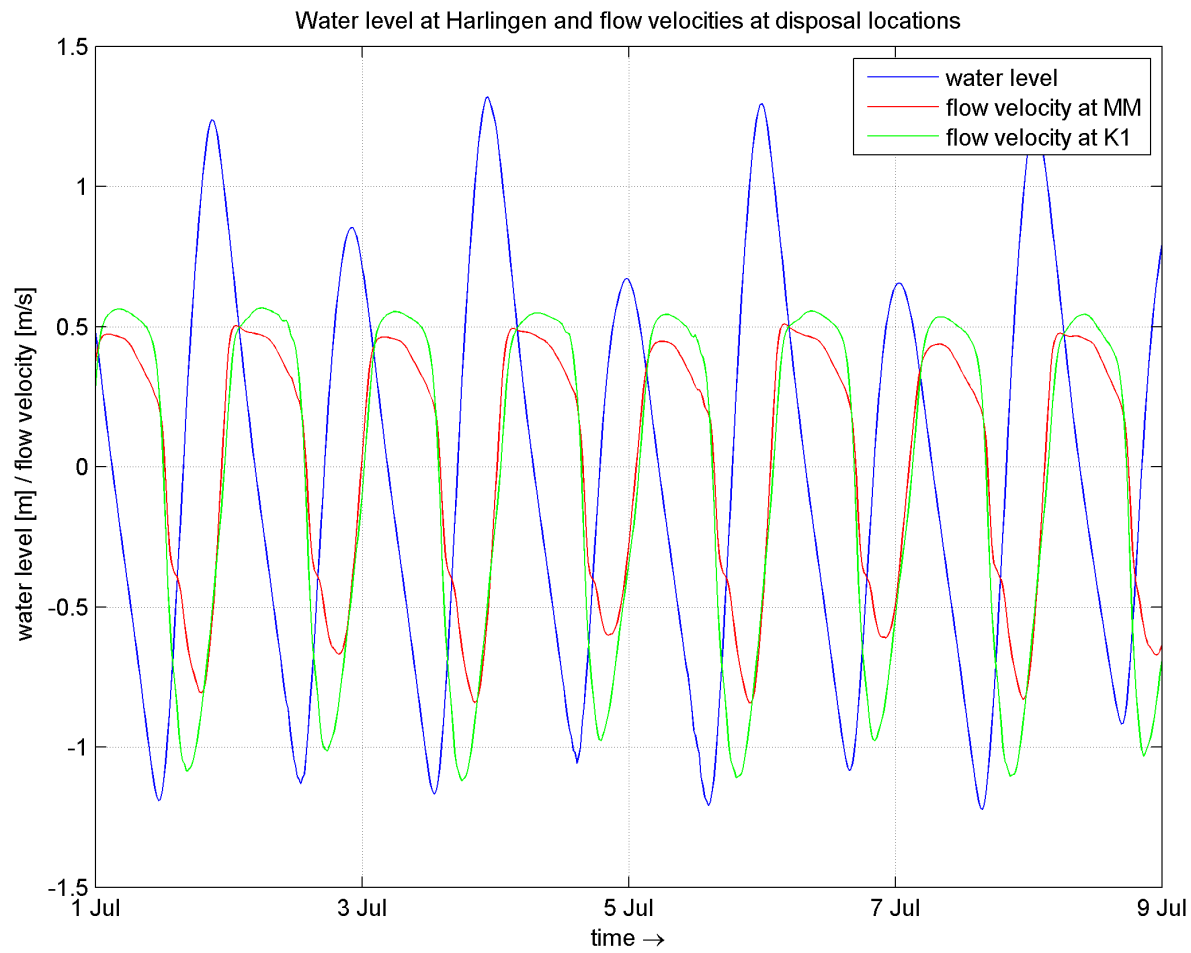

Figure 3-5. Water level at Harlingen (blue) and channel directed flow velocity at the MM disposal location (red).

Note that the estimation of the effectiveness of the disposal locations is based on linearly extrapolating the results at individual sampling points to the entire target area and therefore is only indicative. Moreover, the result of the tracer experiment only applies to short-term dynamics (one month), and is dependent on the hydrodynamic conditions during that particular month. Another remark that should be made with respect to the tracer experiment is that analysis of the soil samples in the lab was done by homogenising and diluting the sample. The dilution factor was however so high, that the typical count per subsample was 1-10 tracer particles, with the majority being 1-3 tracers. This amount is too low to generate a statistically reliable map of the tracer distribution. In hindsight the dilution of the sample should have been lower, more tracer material should have been dispersed, or duplicate / triplicate tests been executed to ensure the accuracy of the (sub) sampling methodology.

The results suggest that after one month $80 \%$ of the mud disposed at the new disposal location reached the Koehoal intertidal area, compared to only $20 \%$ from the existing disposal location, see Table $3-2$ (note that the sampled area covers a larger area than the area targeted for salt marsh accretion, which is primarily the upper mudflat). Both at the sampled area (Figure 3-6) and in the Kimstergat channel and the port, more tracer particles from the new disposal location MM than from location $\mathrm{K} 1$ were retrieved. The tracer experiment can be used to compute the sedimentation thickness at the end of the project, as the number of tracer particles per sample is equivalent with a sediment volume or sedimentation thickness. Assuming that the hydrodynamic conditions during the tracer experiment period of one month is representative for the entire Mud Motor project, the sedimentation thickness can be upscaled to the entire project period. Figure 3-6 shows the estimated sedimentation footprint for a release of 600,000 $\mathrm{m}^{3}$ for release from the existing $\mathrm{K} 1$ location and the new MM location ${ }^{1}$. The estimated sedimentation thickness amounts $1-2 \mathrm{~cm}$ in the major part of the target area for the MM release location. There is some spatial variation, showing higher sedimentation rates closer to the coastline.

The results (Table 3-2) also show an increase of recovery percentage over time. It takes a while before the tracer particles arrive at the target location. In Vroom et al. (2016) is hypothesized that the tracers at $\mathrm{MM}$ have been transported in ebb direction after release at $\mathrm{HW}$, explaining also higher recovery rates

\footnotetext{
${ }^{1}$ In a later stage of the project, the total amount of disposed sediment at the MM location was reduced from 600,000 $\mathrm{m}^{3}$ to $470,000 \mathrm{~m}^{3}$. Thicknesses as presented in Figure 3-6 should therefore be reduced to $470 / 600=78 \%$ of the values indicated by the colour bar.
} 
in the Kimstergat channel and the port, and the slow recovery at the target area. Tracers released at the $\mathrm{K} 1$ location were probably dispersed over a larger area (flow velocities at K1 are generally higher than at $\mathrm{MM}$ ) and possibly have a longer transport time to the target area, although these tracers were also less present in the Kimstergat channel and the port.

Table 3-2. Percent recovery in the area of interest of the tracers released at existing disposal location $\mathrm{K} 1$ and at the new location MM after 5 days, 2 weeks, and one month. See (Vroom et al. 2016) for details.

\begin{tabular}{l|ll} 
Time after release & $\mathrm{K} 1$ & $\mathrm{MM}$ \\
\hline 5 days & $1 \%$ & $13 \%$ \\
2 weeks & $5 \%$ & $12 \%$ \\
1 month & $20 \%$ & $80 \%$
\end{tabular}
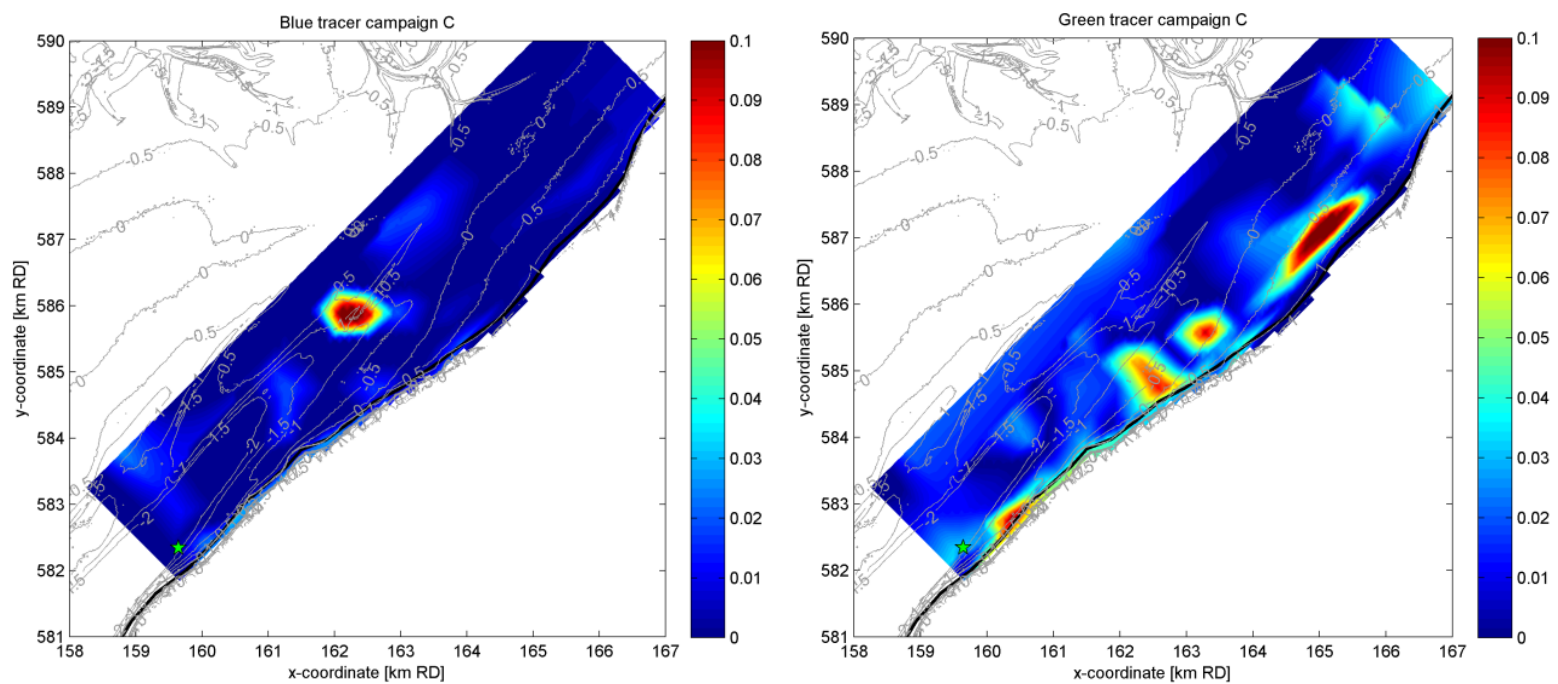

Figure 3-6. Estimated sediment thickness in [m] for a dredging disposal of $600.000 \mathrm{~m}^{3}$, computed by interpolating sample results of last sampling campaign (after 1 month) in space, and scaling tracer count per subsample to total sample. Sedimentation footprint when releasing at location K1 (left) and when releasing at new location MM (right). Location MM is indicated with a green star. Taken from Vroom et al. (2016). 


\section{Monitoring plan and results}

\subsection{Overview of measurements}

An extensive monitoring and research programme was executed to measure the response of intertidal flats and salt marshes to the increased sediment load of the Mud Motor. Monitoring activities in the applied research project of the EcoShape foundation were coupled to the fundamental research programme in the project 'Sediment for salt marshes: physical and ecological aspects of a Mud Motor'financed by the Netherlands Organisation for Scientific Research (NWO-TTW). Detailed observations of sediment transport mechanisms in the Kimstergat channel by (Schulz \& Gerkema 2018) are summarized in sections 4.2.4 and sediment transport mechanisms over the tidal flats were executed by Colosimo et al. (in review) and summarized in section 4.2.5. This chapter starts with the results of the EcoShape project measurements.

The monitoring was focussed on the response of the tidal flats and salt marshes to the Mud Motor pilot on the short (daily to weekly) and the long-term (multiple seasons to years). As the signal of the Mud Motor pilot is relatively small $\left(470,000 \mathrm{~m}^{3}\right.$ of dredged sediment leads to a sedimentation of $1-2 \mathrm{~cm}$ in the majority of the study area, see Figure 3-6), it is very hard to measure an effect specifically from the Mud Motor. So, to get a thorough understanding of the possible contribution of the Mud Motor to the salt marsh expansion, we also use the measurements to study autonomous dynamics on different temporal and spatial scales.

\section{Measurements in the Ecoshape project}

Yearly unmanned aerial vehicle (UAV) orthophotos and (later on) UAV LiDAR measurements were carried out to gain information about mid-term bed level dynamics in the entire unvegetated area of interest and to assess the vegetation dynamics (coverage in Figure 4-1). In addition, if the Mud Motor would lead to sedimentation in a very confined area, we would also be able to monitor it with this dataset. Most $^{2}$ UAV measurements were executed in August/September, to be able to eliminate the seasonal variation in both elevation and vegetation dynamics. Just in front of the salt marsh, the intertidal area has a rough surface with hummocks and hollows with a height of $\sim 10 \mathrm{~cm}$. For the salt marsh to expand, vegetation needs to establish on this part of the intertidal. Therefore, the dynamics of these patterns is relevant (do they migrate? do they disappear and rebuild?), especially since its magnitude of $\sim 10 \mathrm{~cm}$ is an order of magnitude larger than the possible Mud Motor effect.

Sedimentation-Erosion Bars (SEBs) were used to detect sedimentation and erosion on shorter time scales (months) during the entire project period on a large number of locations both in the salt marsh and at the bare mud flat (yellow diamonds in Figure 4-1). The instrument is rather simple (data collection is secured) and has proven great value in measuring sedimentation/erosion dynamics in salt marshes. Surface Elevation Dynamics sensors (SEDs) are new but can give continuous bed elevation data and wave heights. However, as the sensors are still in development phase, the data collection is more insecure. And indeed, over the course of the foreseen measurement period of the SEDs of one year, we struggled with broken instruments and hence data gaps. SEDs were used to investigate the response of the bed to varying hydrodynamics forcing on a time scale of hours on the intertidal flat (further offshore than the SEBs, see blue dots labelled A, B, C in Figure 4-1).

Permanent vegetation Quadrants (PQs) were installed next to the SEBs to detect changes in vegetation species, cover and density as a measure of salt marsh expansion/retreat and couple vegetation changes as seen from the aerial pictures to detailed field data. SEDs and PQs were also placed at Zwarte Haan

\footnotetext{
${ }^{2}$ Mounting LiDAR to an UAV was new and the only possibility to gain full coverage elevation data, as orthophotos were too inaccurate for the very flat and shimmering intertidal area, which we concluded after the first recording. Making the UAV LiDAR operational delayed the LiDAR measurement in the second year but gave reasonably good results.
} 
as a control site. We tested statistically whether sedimentation was related to different vegetation characteristics, such as vegetation cover, vegetation height and elevation.

The monitoring consists of full coverage unmanned aerial vehicle (UAV) orthophotos and UAV LiDAR, local sedimentation-erosion measurements, ship-borne measurements and vegetation quadrants. The time schedule of the execution of the measurements shown in Figure 4-3. In this section, first the measurements on sediment dynamics are introduced and explained, followed by the measurements of the vegetation.

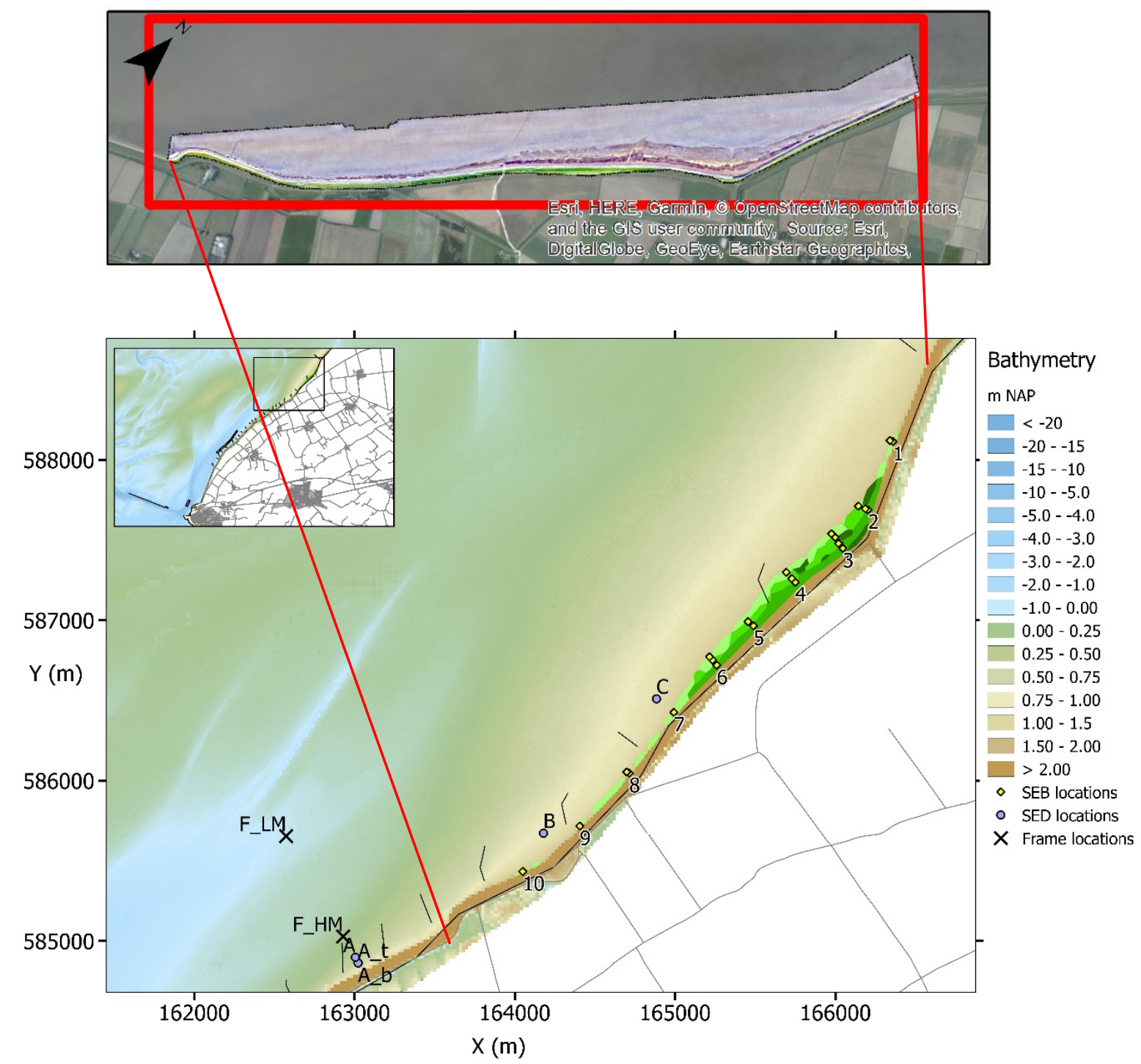

Figure 4-1. LiDAR coverage (top) and measurement locations (bottom). F LM, F HM are hydrodynamic and suspended sediment frame locations. $A, A \_t, A \_b, B$ and $C$ are Surface Elevation Dynamics (SED) sensor locations. Transects 1 to 10 show 22 Sedimentation-Erosion Bar (SEB) locations in the salt marsh, with adjacent permanent quadrats (PQ). Coordinates shown in Dutch grid EPSG:28992. Bright green colours indicate vegetation. Black lines indicate groins.

Measurements in the NWO-TTW project

In the NWO-TTW project, two PhD-students and a post-doc have been executing measurements as well. These measurements included 13-hour measurements of flow, salinity and sediment concentration in the Kimstergat channel (location C1 and C2 in Figure 4-2) to determine sediment transport processes (Kirstin Schulz), detailed flow, wave, bed level and suspended sediment concentration measurements at two measuring frames (FLM and FHM in Figure 4-2) on the intertidal flats for two periods of one month 
(Irene Colosimo), and measurements of establishment of vegetation in the transition zone between salt marsh and tidal flat (Marin van Regteren).

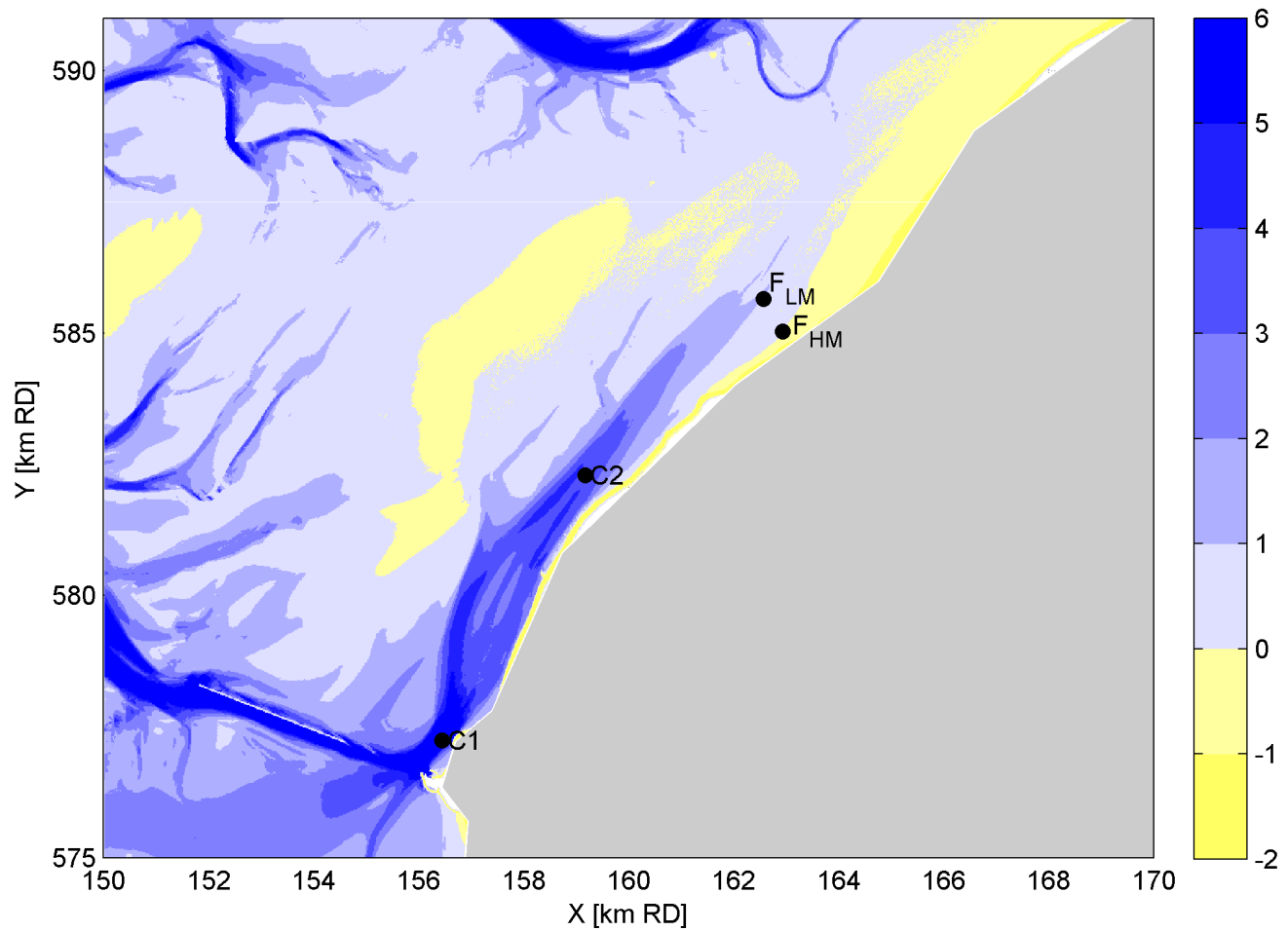

Figure 4-2. Hydrodynamic and sediment transport observation locations. C1 is the old disposal location and C2 is the new (mud motor) disposal location. F indicates the locations of the frame deployed by Colosimo et al (in review), with $F_{L M}$ being the frame at the lower mud flat and $F_{H M}$ the frame at the higher mud flat.

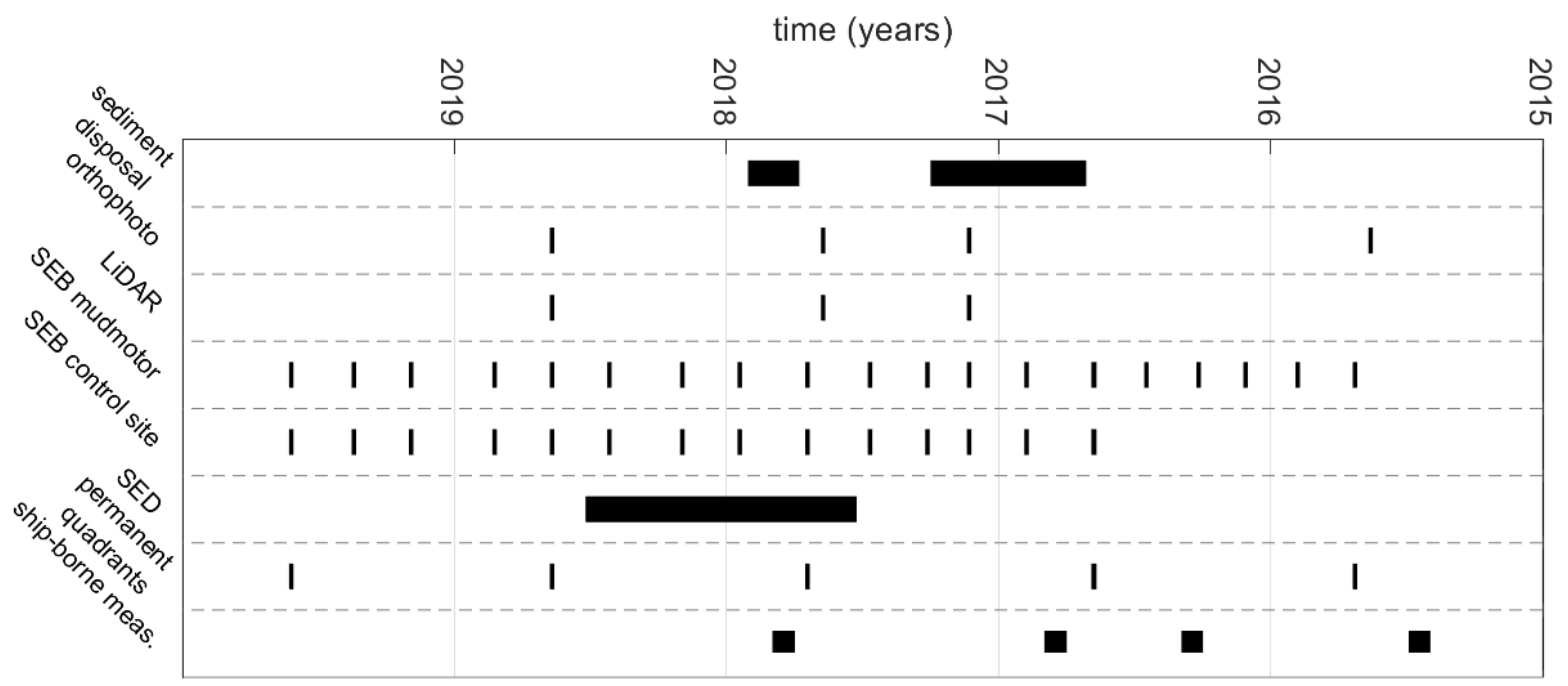

Figure 4-3. Overview of all field measurements over time, with time at the $y$-axis and the Mud Motor sediment disposal and field measurements at the $x$-axis. 


\subsection{Sediment dynamics}

\subsubsection{Sedimentation-Erosion Bars}

\section{Methods}

The multi-annual surface-elevation change was determined with Sedimentation-Erosion Bars (SEBs). This instrument is described in (Nolte et al. 2013). The setup consists of two horizontally aligned poles inserted into the ground until they reach a stable horizon. During measurements, a $2 \mathrm{~m}$-long bar with 17 holes $10 \mathrm{~cm}$ apart is placed on the poles and a ruler is placed through these holes to measure the distance to the soil surface. The 17 measurements from the SED to the ground are averaged, to collect a single bed level. With repeated measurements the bed level change over time can be calculated. The accuracy of the surface elevation is about $1.5 \mathrm{~mm}$ vertically. Additionally, the thickness of the freshly deposited soft mud layer on top of the more consolidated bed was measured for each SEB bar. The transition between soft mud and consolidated mud was determined based on the tactile resistance of the measuring stick (ruler) while placing it at the bed.

In February 2015, 22 stations were established in 10 alongshore transects at the Mud Motor site on a vegetated salt marsh (Figure 4-1). In August 2016, 19 additional stations were placed at the 10 transects on the Mud Motor site to add stations at the bare mudflat. Simultaneously, 15 stations were established in 4 alongshore transects at a control site Zwarte Haan. The surface elevation was measured every two to three months, until August 2019. In February 2018 the ground was frozen when the surface elevation was measured. This may have resulted in an error of the measured surface elevation, as it was not possible to measure the thickness of the soft mud layer.

\section{Effect Mud Motor on medium-term sedimentation}

Results of the measurements with Sedimentation-Erosion Bars show relatively large changes in surface elevation. Layers of soft mud with a thickness of up to $10 \mathrm{~cm}$ were deposited in some locations in the salt marsh over a two to three-month period up to September, and they disappeared just as fast up to March. As a result, the annual sedimentation rates in August of each year ranged between $-3.75 \pm 0.55$ $\mathrm{cm}$ and $+5.87 \pm 0.58 \mathrm{~cm}$ (Table 4-1), which is comparable with sedimentation rates of other salt marshes along the Friesland Coast (Dijkema 2011).

Table 4-1. The annual sedimentation rates for the two different sites: Koehoal-Westhoek (Mud Motor site) and Zwarte Haan (Control site), the sedimentation rate was measured at the end of August / beginning of September.

\begin{tabular}{|l|l|l|l|l|}
\hline Location & Period & $\begin{array}{l}\text { Mud motor } \\
\text { volumes }\left(\times 10^{3}\right. \\
\left.\mathrm{m}^{3}\right)\end{array}$ & $\begin{array}{l}\text { Salt-marsh } \\
\text { sedimentation } \\
\text { rate }(\mathrm{cm} / \mathrm{yr})\end{array}$ & $\begin{array}{l}\text { Mudflat } \\
\text { sedimentation } \\
\text { rate }(\mathrm{cm} / \mathrm{yr})\end{array}$ \\
\hline Mud motor site & Aug 2015 - Aug 2016 & 0 & $2.09 \pm 0.37$ & - \\
\hline Mud motor site & Aug 2016 - Aug 2017 & 300 & $3.92 \pm 0.73$ & $5.87 \pm 0.58$ \\
\hline Control site & Aug 2016 - Aug 2017 & 0 & $3.71 \pm 1.48$ & $0.30 \pm 0.77$ \\
\hline Mud motor site & Aug 2017 - Aug 2018 & 170 & $-1.10 \pm 1.05$ & $-3.75 \pm 0.55$ \\
\hline Control site & Aug 2017 - Aug 2018 & 0 & $-4.40 \pm 0.86$ & $2.08 \pm 1.25$ \\
\hline Mud motor site & Aug 2018 - Aug 2019 & 0 & $1.62 \pm 0.57$ & $2.59 \pm 0.49$ \\
\hline Control site & Aug 2018 - Aug 2019 & 0 & $1.17 \pm 1.21$ & $4.36 \pm 0.43$ \\
\hline
\end{tabular}

In the first winter of the Mud Motor pilot there was no significant difference in sedimentation compared to the Control site (Figure 4-4). However, in the second Mud Motor winter there was a significant increase in sedimentation compared to the first Mud Motor winter and compared to the Control site. The annual sedimentation rate at the Mud Motor site showed erosion in the Aug 2017 - Aug 2018 period (Table 4-1). This indicates that the high sedimentation from the $2^{\text {nd }}$ Mud Motor winter was eroded due to natural circumstances, since the erosion also showed at the marsh in the Control site. 


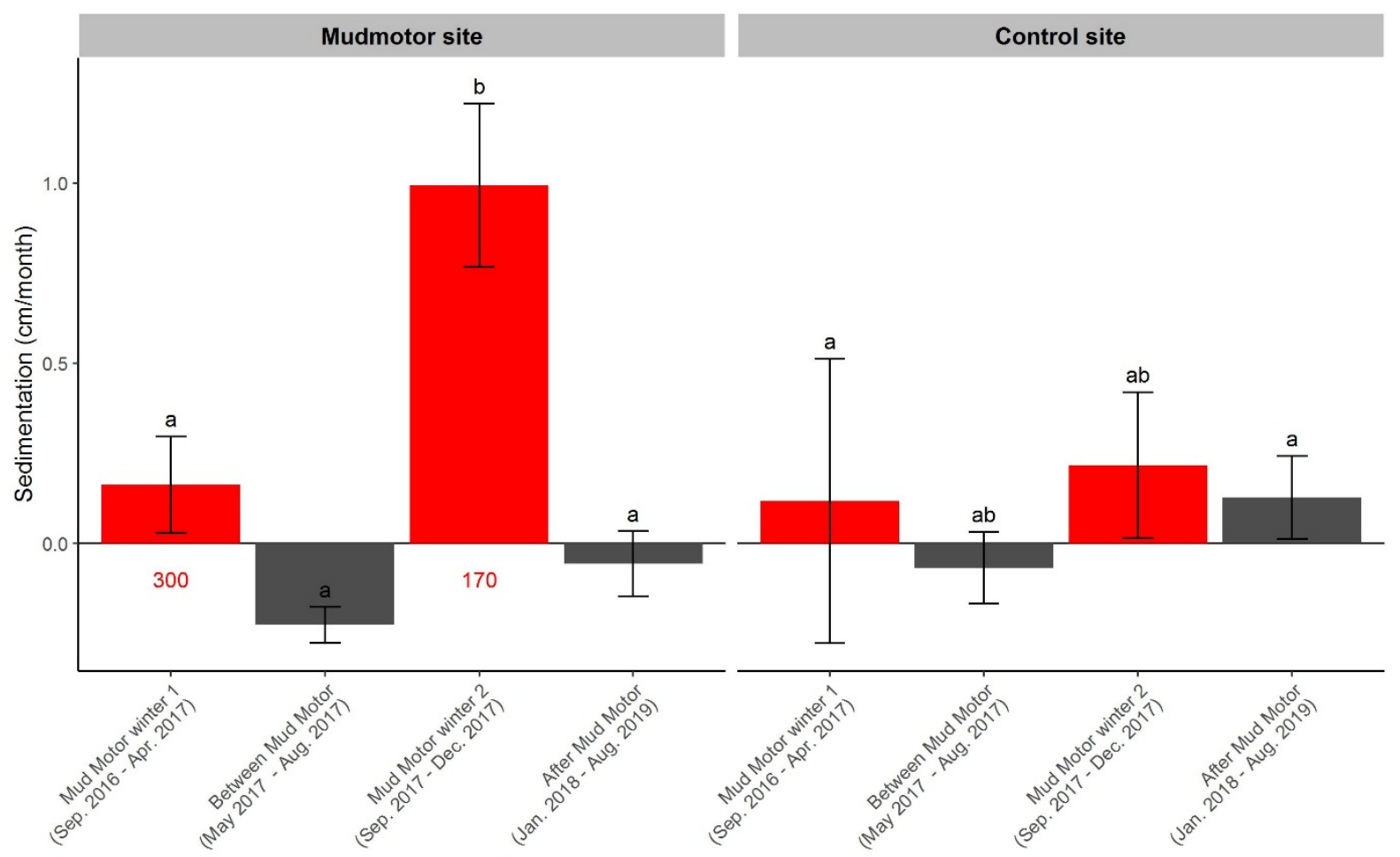

Figure 4-4. Absolute sedimentation (cm) during (red), between and after the Mud Motor (black). The sedimentation is shown for Westhoek (Mud Motor site) and Zwarte Haan (control site). In Zwarte Haan the measurements started at the beginning of the first Mud Motor winter. Numbers denote disposed volumes $\left(\times 10^{3} \mathrm{~m}^{3}\right)$. Letters denote the significant difference between the bars.

The distance between the Mud Motor and the Control site is $6 \mathrm{~km}$. Compared to the Mud Motor site the Control site had lower sediment dynamics (Figure 4-4). This is probably explained by the different orientation of the coastline with respect to the dominant SW wind direction.

Within the Mud Motor site the spatial variability in sedimentation was substantial with larger sediment dynamics (erosion as well as accretion) in the southern transects compared to the northern transects. In general, the southern transects had no nett bed level change, whereas the mudflat and the salt marsh on the northern transects nett increased in bed level between 2016 and 2018. This is also related to the orientation of the coast line and the more sheltered conditions in the indentation of the dike at Westhoek.

\section{Soft mud}

In salt marshes highest sedimentation rates generally occur during the winter season, and compaction of the sediment through drought and self-weight occurs in summer (Dijkema et al. 2011). In both field sites we found the same pattern. The high sedimentation in winter was overall related to the deposition of a layer of fresh deposits with low strength (soft mud) on top of a more consolidated sediment layer (Figure 4-5). This soft mud layer disappears again in summer, due to either compaction or erosion. If the soft mud layer persists over a few successive warm days without any inundation, this will dry out the soft mud and it becomes fixated on top of the old sediment layer. However, often the soft mud layer is eroded by waves and tidal currents before it gets fixated. Our two- or three-monthly measurements could not differentiate between the processes of erosion and compaction, but did show large fluctuations in bed height. The soft mud layer disappears almost completely from the mudflat and in the pioneer zone where there is less sedimentation (Figure 4-7 \& 5-14). In contrast, in the low and high marsh there is a larger increase in elevation, implying that the vegetation holds the soft mud in place and it is less likely to erode during inundations.

\section{Sedimentation at different salt marsh zones}

The different salt marsh zones have differences in inundation time, vegetation density and height, this results in differences in sedimentation. At both sites the mudflat and pioneer zone have similar sedimentation patterns, were sedimentation and erosion balance each other, resulting in a stable bed. 
The highest sedimentation is at the lower salt-marsh zone, which has more sedimentation and less erosion, most likely due to the presence of vegetation (Figure 4-7 \& 4-14). The vegetation traps the sediment and reduces erosion. The high marsh has less sedimentation, most likely because the inundation time and consequently the hydrodynamic activity at the high marsh is lower compared to the low marsh. In contrast to the pioneer and mudflat, the soft mud at the low and high marsh is less eroded (Figure 4-5 \& 12).

\section{Sediment budget of the salt marsh}

Based on the average sedimentation rate $(\mathrm{cm} / \mathrm{yr})$ for the pioneer zone, low and high marsh together and the salt-marsh surface area we can calculate the total sediment budget that was deposited on the salt marsh each year. The total sediment budget was highest in 2016-2017 and lowest in 2017-2018 (Table 4-2). For 2017-2018 there was overall erosion, as was also indicated in the decrease in saltmarsh sediment. The values are low compared to the amount of disposed material, however this yearly sedimentation measured in August is partially consolidated mud, and therefore it is difficult to compare with unconsolidated material.

Table 4-2 Total increase in consolidated sediment for the salt marsh in 2015- $2018\left(\mathrm{~m}^{3}\right)$, and the Mud Motor volume disposed $\left(m^{3}\right)$.

\begin{tabular}{l|l|l} 
& $\begin{array}{l}\text { Total increase/decrease in } \\
\text { consolidated sediment in salt } \\
\text { marsh }\left(\mathrm{m}^{3}\right)\end{array}$ & $\begin{array}{l}\text { Mud Motor } \\
\text { volume }\left(\mathrm{m}^{3}\right)\end{array}$ \\
\hline $2015-2016$ & 6,242 & 0 \\
$2016-2017$ & 10,348 & 300,000 \\
$2017-2018$ & $-3,082$ & 170,000
\end{tabular}

\section{Mud Motor site}

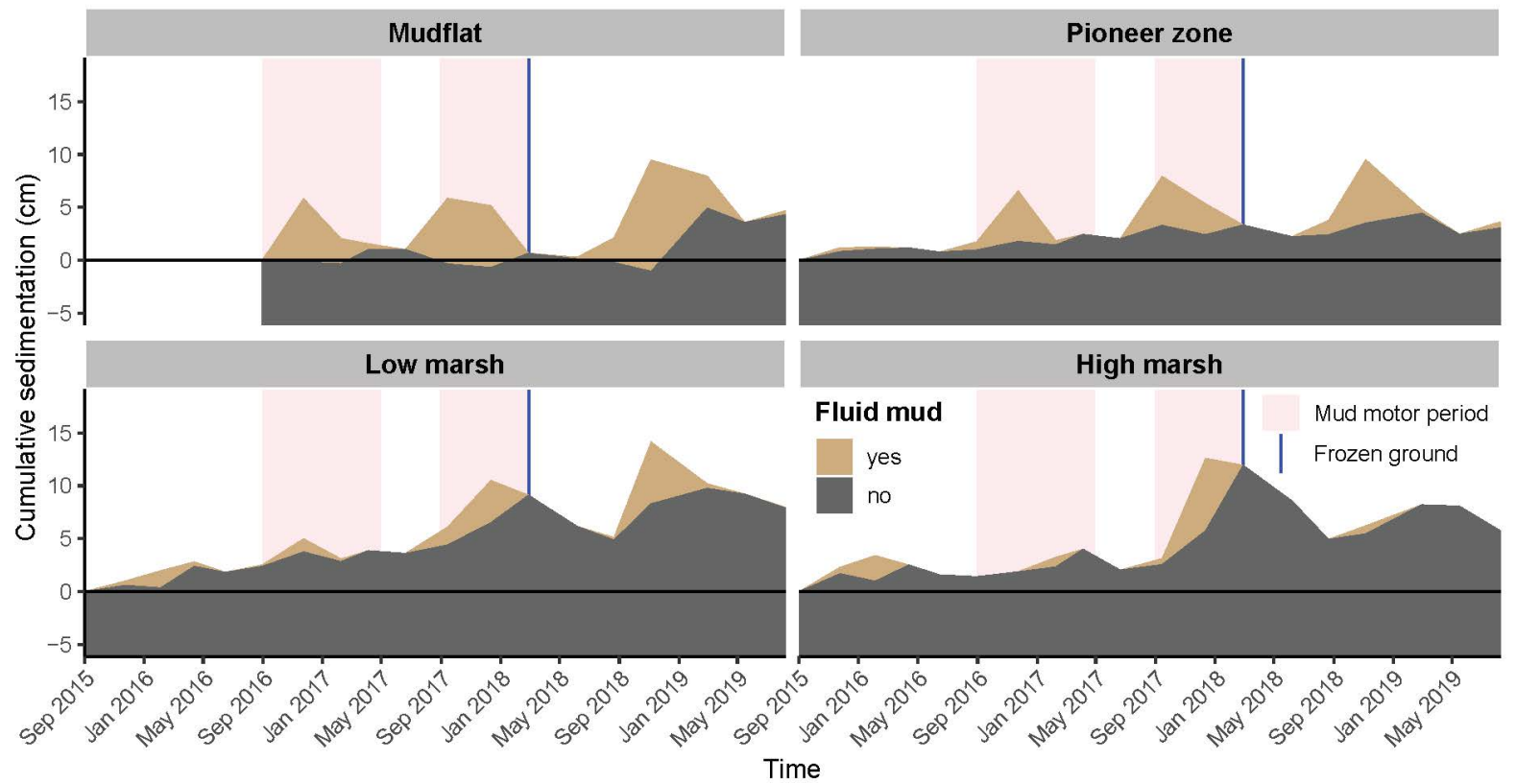

Figure 4-5 The cumulative sedimentation at Westhoek (Mud Motor site) distinguished between consolidated mud and soft mud for the four vegetation types. In February 2018 the ground was frozen, which made it impossible to measure the soft mud layer thickness. 


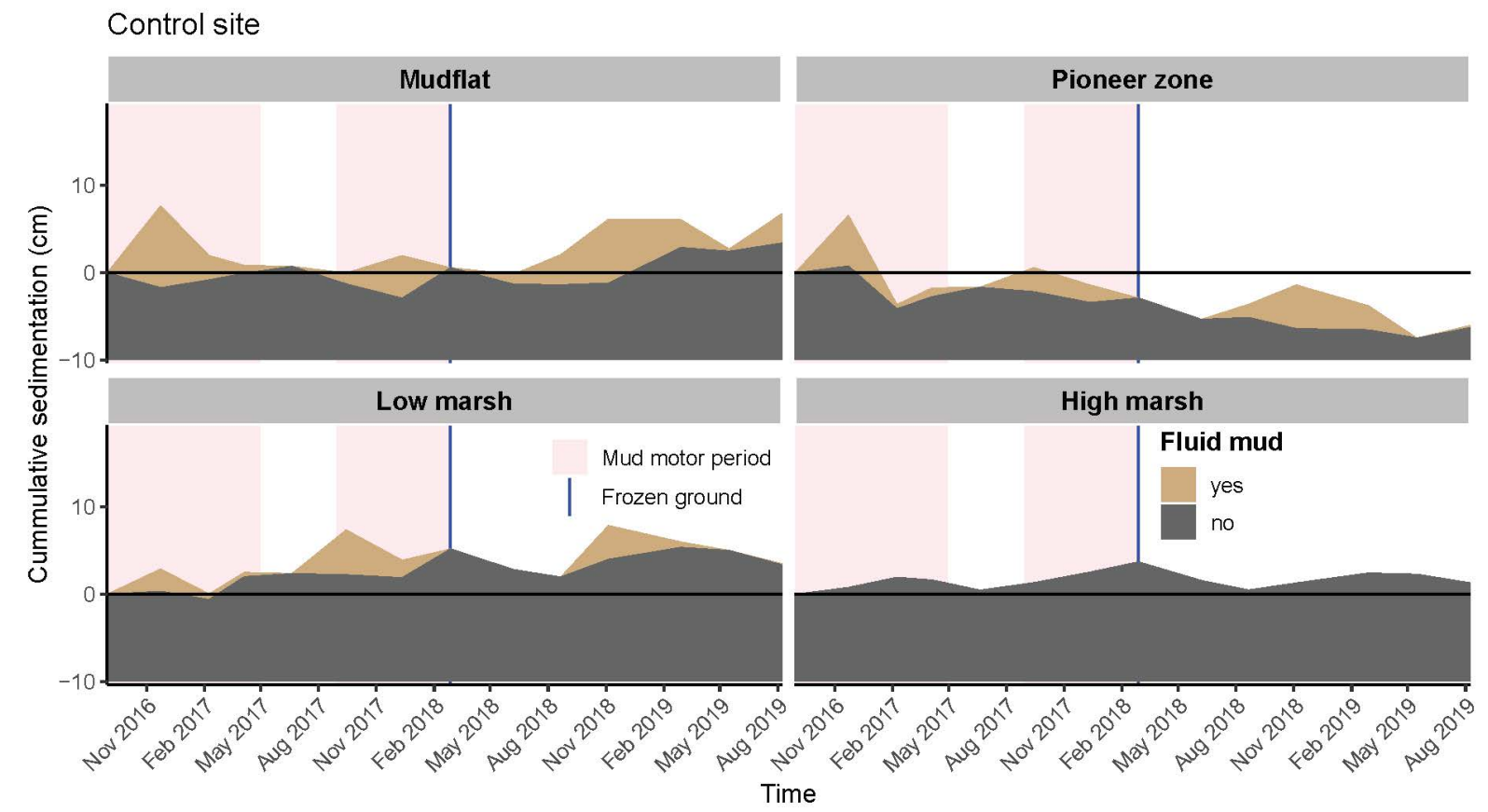

Figure 4-6 The cumulative sedimentation at Zwarte Haan (control site) distinguished between consolidated mud and soft mud for the four vegetation types. In February 2018 the ground was frozen, which made it impossible to measure the soft mud layer thickness.

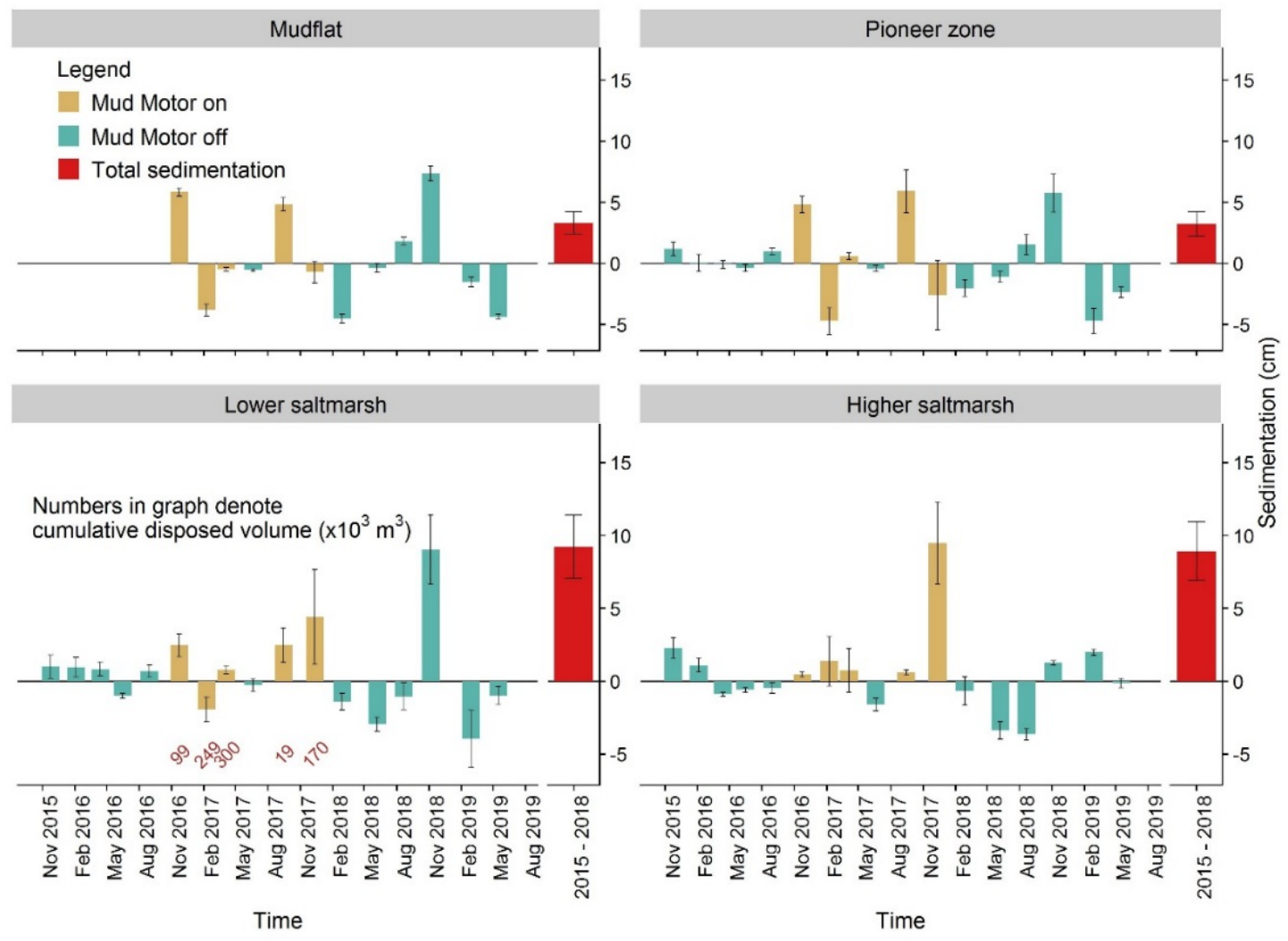

Figure 4-7. Sedimentation and erosion of the Westhoek salt marsh (Mud motor site) for the four different vegetation types over time. The red bars on the right in each graph represents the nett surface elevation change over the entire period. Means and standard errors are shown. Numbers in the lower salt marsh graph denote disposed volumes $\left(\times 10^{3} \mathrm{~m}^{3}\right)$. 


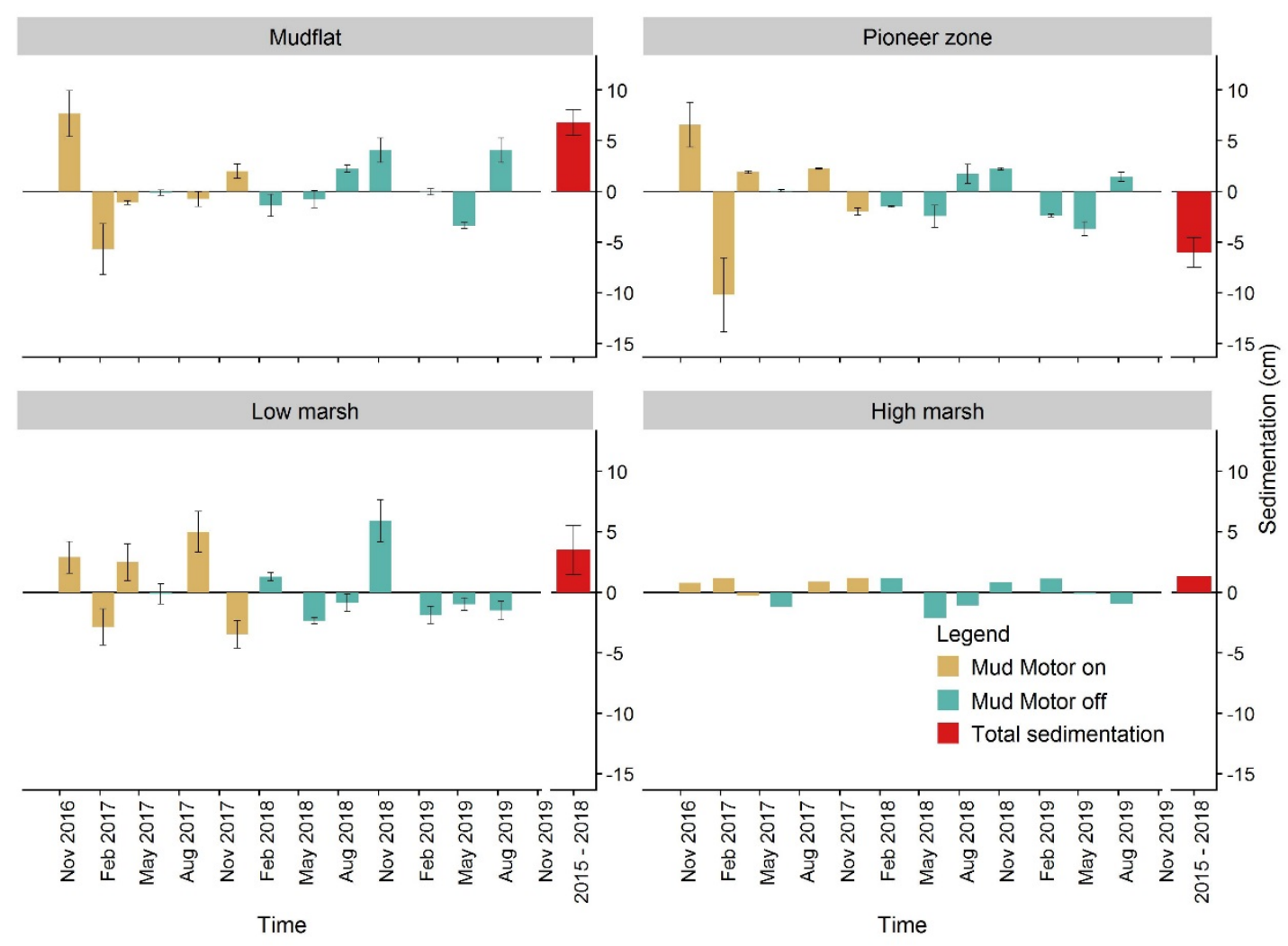

Figure 4-7. Sedimentation of the Zwarte Haan salt marsh (control site) for the four different vegetation types over time. The red bar indicates the total sedimentation over the period. Means and standard errors of the means are shown.

\subsubsection{Surface Elevation Dynamics sensors}

\section{Methods}

Short-time surface elevation changes were determined with Surface Elevation Dynamics (SED) sensors. An extensive description with illustrations of this novel instrument is found in (Hu, Lenting, et al. 2015). A SED-sensor is essentially a pin containing a semi-continuous array of 200 light sensitive cells that is inserted vertically in the sediment leaving approximately half of the measuring section above the seabed. The aboveground cells and belowground cells give high and low voltage outputs accordingly, resulting in a transition point at the bed level. The distance between two adjacent cells is 2 $\mathrm{mm}$, and the measuring interval can be set from one second to a few hours, depending on the application. The measurement interval used in the current study was 30 minutes. The applied SEDsensors rely on daylight, and hence do not work overnight or when submerged. Updated sensors are being developed with hydro-acoustic sensors, to be able to measure overnight and when submerged. The SEDs placed at our project site also contain pressure sensors to measure waves at an interval of 10 minutes. In the target area 5 SED-sensors were deployed from mid-July 2017 till January 2018 and two sensors between mid-April 2018 and July 2018. SED-sensors were placed at three locations A, B and $C$ at $100 \mathrm{~m}$ distance from the dike toe or salt marsh edge (if present) and also at $A_{\text {bottom }}$ (i.e. $A_{b}$ ) at the bottom of a hollow and at $A_{\text {top }}$ (i.e. $A_{t}$ ) on top of a hummock at $60 \mathrm{~m}$ from the dike toe (Figure 4-1). The SEDs were checked approximately every eight weeks to ensure data collection, clean the sensors and retrieve the data. Collected raw data from the Surface Elevation Dynamics (SED) sensors were converted using well-documented software (Willemsen et al. 2018).

\section{Dynamics}

Results from the Surface Elevation Dynamics (SED) sensors allocated at the bare mudflat seaward from the salt marsh are in agreement with the SEB measurements and also show rather large and fast bed level variations with accretion/erosion events of up to $10 \mathrm{~cm}$ on a time scale of days (e.g. $7 \mathrm{~cm}$ accretion in November at location B and C and $10 \mathrm{~cm}$ erosion in September at location At), Figure 4-8. Such 
changes were not observed in other tidal flats at a similar distance from the salt marsh edge or dike toe using similar instruments (Hu et al., 2017; Willemsen et al., 2018). These large bed level fluctuations indicate the highly dynamic character of the study site. An increase in sedimentation rates in relation with disposed Mud Motor volumes (blue shading Figure 4-8) could not be established.

\section{Difference between low and high areas}

The bed level height at the western part of the study site (near SED measurement locations $A$ ) is situated lower than the eastern part of the study site (Table 4-3). The significant lower lying measurement locations $A_{t}, A_{b}$ and $A$ (Figure 3-2), showed more short-term bed level fluctuations (days/weeks), than the measurement locations located higher in the tidal frame at measurement locations $B$ and $C$ (Figure 3-2). At a smaller spatial scale, a small difference in bed level was observed between the hummocks and hollows at the hummock/hollow pattern (as described in section 5.1.1). Sediment dynamics at the smaller scale of the hummocks and hollows were measured at location $A_{\text {top }}$ and $A_{\text {bottom }}$ respectively. The short-term dynamics were much larger in the hollows (Fig. 5-15) than at the hummocks. However, no temporal trends were observed at neither of the locations over the assessed period, suggesting no influence of short-term sediment dynamics over the medium-term development of the pattern.

Table 4-3. Average bed level height at the measurement locations, periodically measured with RTK-DGPS

\begin{tabular}{|l|l|}
\hline Measurement location & Bed level height \\
\hline$A_{\text {top }}-60 \mathrm{~m}$ from dike toe & $0.45 \mathrm{~m}+\mathrm{N}$. A.P. \\
\hline Abottom $-60 \mathrm{~m}$ from dike toe & $0.35 \mathrm{~m}+\mathrm{N}$. A.P. \\
\hline A $-100 \mathrm{~m}$ from dike toe & $0.25 \mathrm{~m}+\mathrm{N}$. A.P. \\
\hline B $-100 \mathrm{~m}$ from vegetation edge & $0.80 \mathrm{~m}+\mathrm{N}$.A.P. \\
\hline C $-100 \mathrm{~m}$ from vegetation edge & $0.90 \mathrm{~m}+\mathrm{N}$. A.P. \\
\hline
\end{tabular}

\section{Importance of events}

Bed level change depends on local settings and hydrodynamic activity. Wind speed during the measurement period was measured at Leeuwarden. Whereas water levels, both astronomical and actual, were measured at Harlingen. The water level setup (actual water level minus astronomical water level) was obtained and relatively large setup (>1 m), was extracted (green shading; Figure 4-8). High wind speeds at Leeuwarden occur mostly in fall and winter (September - February) and comply with relatively large water level setup at Harlingen. Sudden bed level changes occur at the same time as relatively large setup events, mainly at the measurement sites allocated lower in the tidal frame $\left(A_{t}, A_{b}\right.$, A). These events might affect the presence or absence of soft mud on the mud flat. In between periods with abrupt changes, the bed level change seems to follow the spring-neap cycle. Additionally, calm periods with low wind speeds not directed onshore seem to stabilize the deposited sediment. Whether deposited sediment remains at the bed for a longer period and thereby contributes to bed level increase, cannot be derived directly from these measurements. Nevertheless, it can be hypothesized that the right wind conditions play a role. 


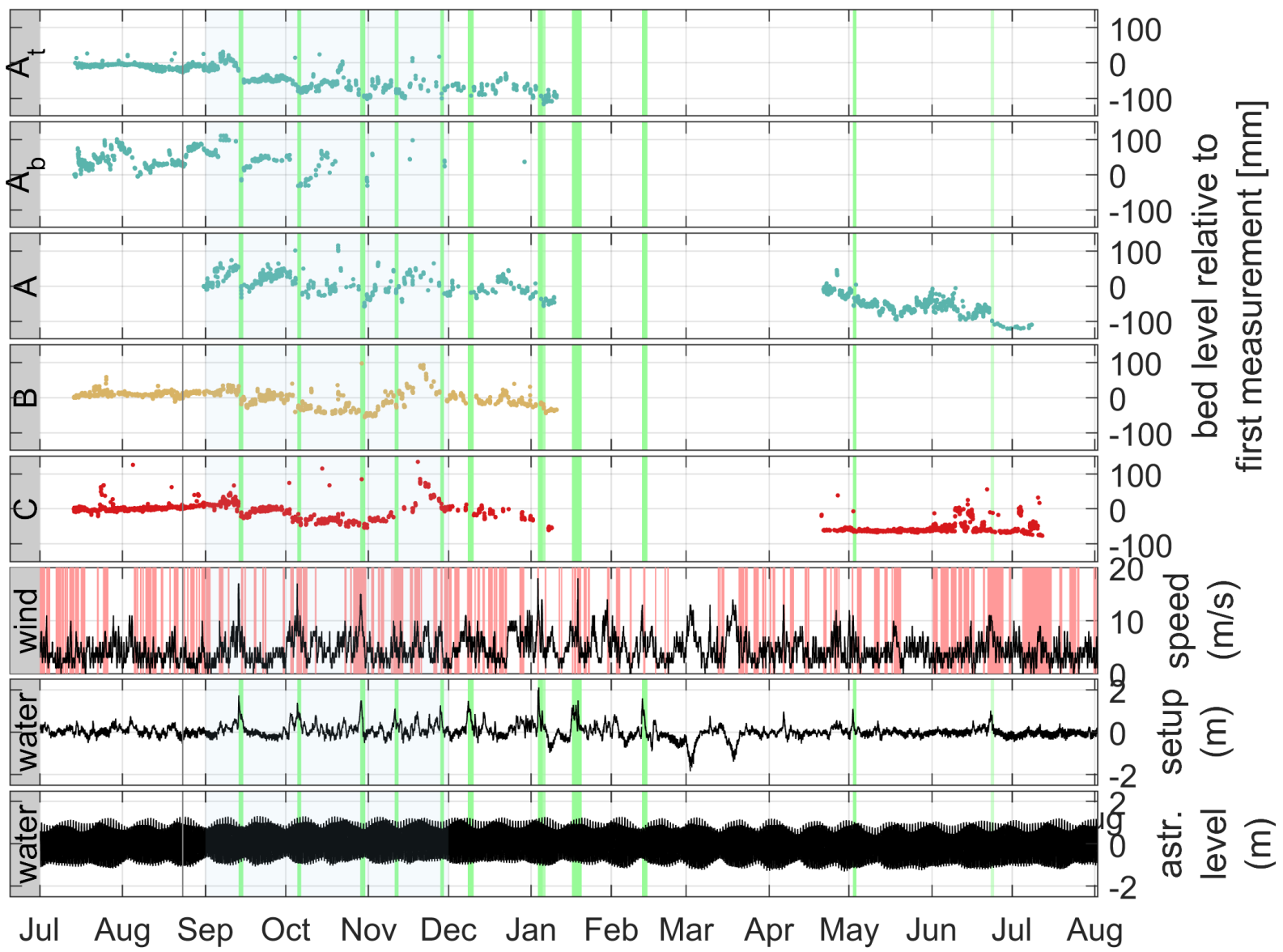

Figure 4-8. Results in bed level variation as measured by 5 SED-sensors, at positions A, B and C at $100 \mathrm{~m}$ from the dike toe and position At the top of a hummock and $A b$ at the bottom of a hollow at $60 \mathrm{~m}$ from the dike toe, see Figure 4-1 for locations. Measurements were conducted in 2017 and 2018. The shading, in the period September - October, indicates in what period Mud Motor volumes were disposed. Hydrodynamic forcing is represented by wind speed, water level set up and astronomical water level. Relative high set up $(>1 \mathrm{~m})$ is highlighted in green. Periods with wind direction perpendicular to the Koehoal study site $\left(>270^{\circ}\right.$ and $\left.<360^{\circ}\right)$ are highlighted in red.

\subsubsection{LiDAR}

\section{Methods}

For a synoptic view of the surface level of the mudflats and salt marsh, an Unmanned Aerial Vehicle (UAV) with on-board LiDAR was flown annually over the study area. Light Detection And Ranging (LiDAR) works by sending laser pulses into an array of accurately defined directions in fast succession. Measuring the travel time for each laser-pulse to be reflected from the targets and returned to the LiDARscanner allows reconstruction of distances and directions of surfaces surrounding the scanner. Attaching a LiDAR scanner to a moving platform like a UAV allows 3D mapping of larger surface areas as the UAV platform is moving ahead. While scanning the surface, the UAV also makes aerial orthophotos mapping the study area. Although the vertical accuracy of the scans is in the same order of magnitude of the average expected increase in bed level by the Mud Motor, the scans can be used to assess possible local bed level changes with a larger magnitude and changes in the small-scale morphology. The bare mudflat in front of the salt marsh is characterised by a pattern of small hollows and hummocks, with a size of several meters and a height of several decimetres that are clearly captured by the LiDAR images.

LiDAR measurements with a gridded resolution of $0.25 \mathrm{~m}$ are performed resulting in a digital elevation model (DEM) of the mudflats and salt marshes northeast of the Mud Motor. These measurements provide insight in the overall bed level changes of the mudflats near Koehoal which could partly be 
attributed to the effect of the Mud Motor. Besides, these measurements show the patterns of the small hollows and hummocks, with a size of several meters. Having several spatial measurements in time allows to analyse the variability of these small channels in locations and depth. This gives insight in the natural variability of the study site and the accommodation space for soft mud in the hollows. Three measurements are taken and presented in this section:

- $\quad T 1$, taken on the $6^{\text {th }}$ February 2017

- T2, taken on the $23^{\text {th }}$ August 2017

- T3: taken on the $21^{\text {st }}$ August 2018

The DEM is validated by comparing with several RTK-GNSS ground validation points. Deviations in the order of $\pm 5 \mathrm{~cm}$ are found between the LiDAR measurements and the validation points. More information about these measurements can be found in the field reports delivered by Shore Monitoring \& Research BV (de Weger 2017; de Zeeuw 2017; Gulden 2018).
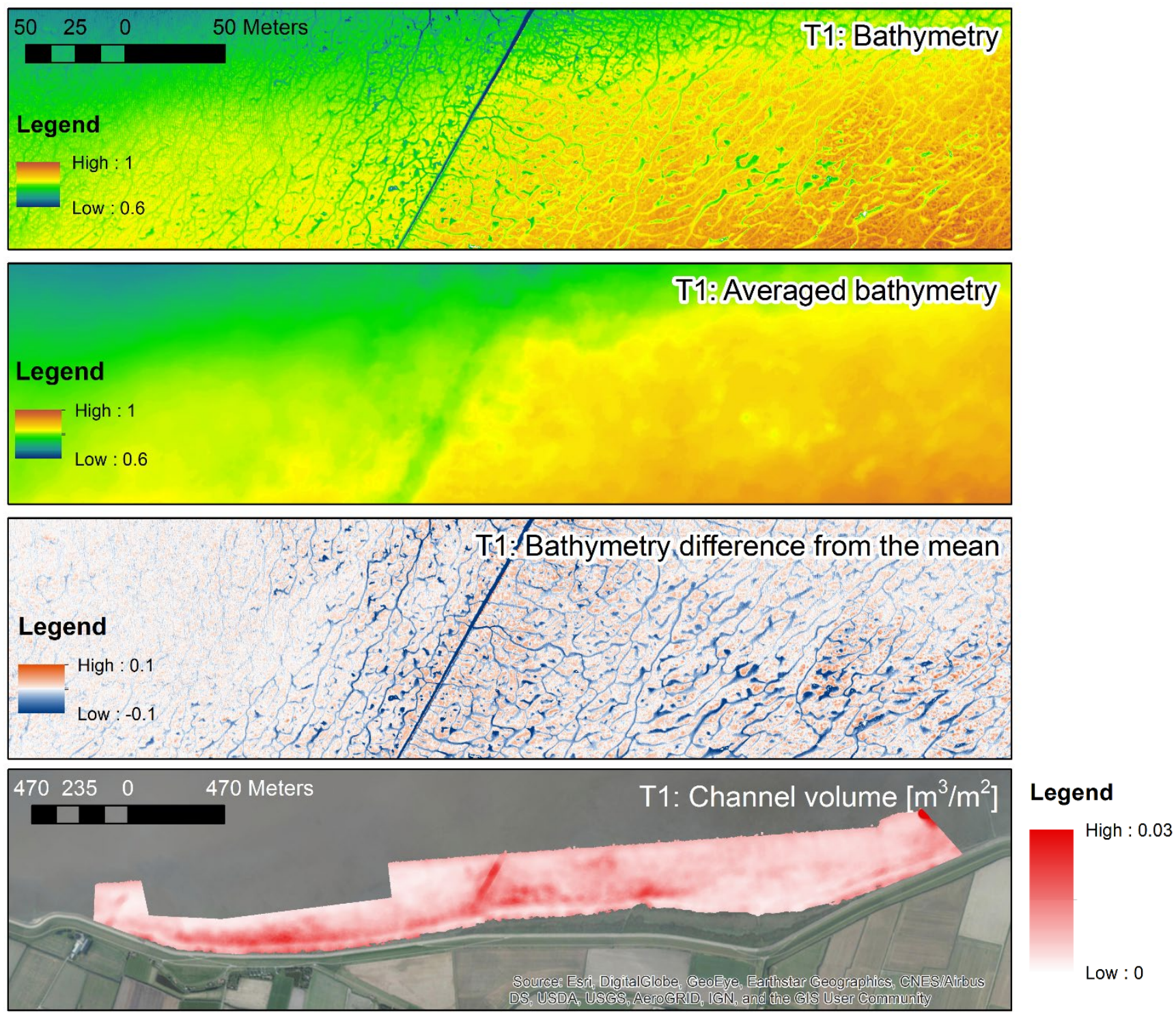

Figure 4-9. Method to extract the channel patterns from the DEM model: applying a median filter with a size of $6 \mathrm{~m}$ to obtain an averaged bathymetry and subtract these values from the original bathymetry. Channel volume is computed by only using negative values and averaging over the surface. Darker red means larger channel volume.

To visualise the patterns of hollows and hummocks, the bathymetry of the intertidal area below $1.2 \mathrm{~m}$ +NAP (as the presence of vegetation at higher bed levels introduces errors) is smoothed by applying a moving circular median filter with a size of $6 \mathrm{~m}$ on the bathymetry (second image of Figure 4-9). The 
pattern of hollows and hummocks in the third image of Figure 4-9 is obtained by subtracting the averaged bathymetry from the original bathymetry (top panel Figure 4-9).

The existence and profoundness of the bed irregularities is measured by computing the channel patterns. From the channel pattern (third panel Figure 4-9), only the negative values representing the hollows / channels are used. A moving average filter is applied on this data and the negative values are multiplied by -1 to get a positive value that represent the channel volume per square meter surface area $\left[\mathrm{m}^{3} / \mathrm{m}^{2}\right]$ (lower panel Figure 4-9).

\section{Net bathymetric changes}

The individual LiDAR maps are visualised in Figure 4-10. It shows that the intertidal area has a gentler slope in front of the salt marsh and is most steep at the southwest side of the study area (left in the maps). The bathymetric changes between these measurements are visualised in Figure 4-11. At the end of the first period between February 2017 (T1) and August 2017 (T2), shortly after the first disposal season, the observed bed level changes are between +0.1 and $-0.1 \mathrm{~m}$. Close to the salt marsh or dike, the sedimentation is largest and in between this part and the seaward side of the LiDAR can a blue band is visible. This might be an artefact of the scanning technique. In the period between August 2017 (T2) and August 2018 (T3), an overall bed level lowering is measured. It should be noted here that the T3 LiDAR measurement shows a 0.05 to $0.10 \mathrm{~m}$ lower bed level compared to the RTK-GNSS ground validation points located in the mud flat area which is in the same order as the difference between measurement T3 and T2 (Gulden 2018). It is therefore expected that part of the bed level decrease can be attributed to a measurement inaccuracy. However, the SEBs also show erosion in 2017-2018 both at the Mud Motor and the Control Site. Comparing the bathymetry of T3 with T1, minor erosion and deposition changes are visible. 

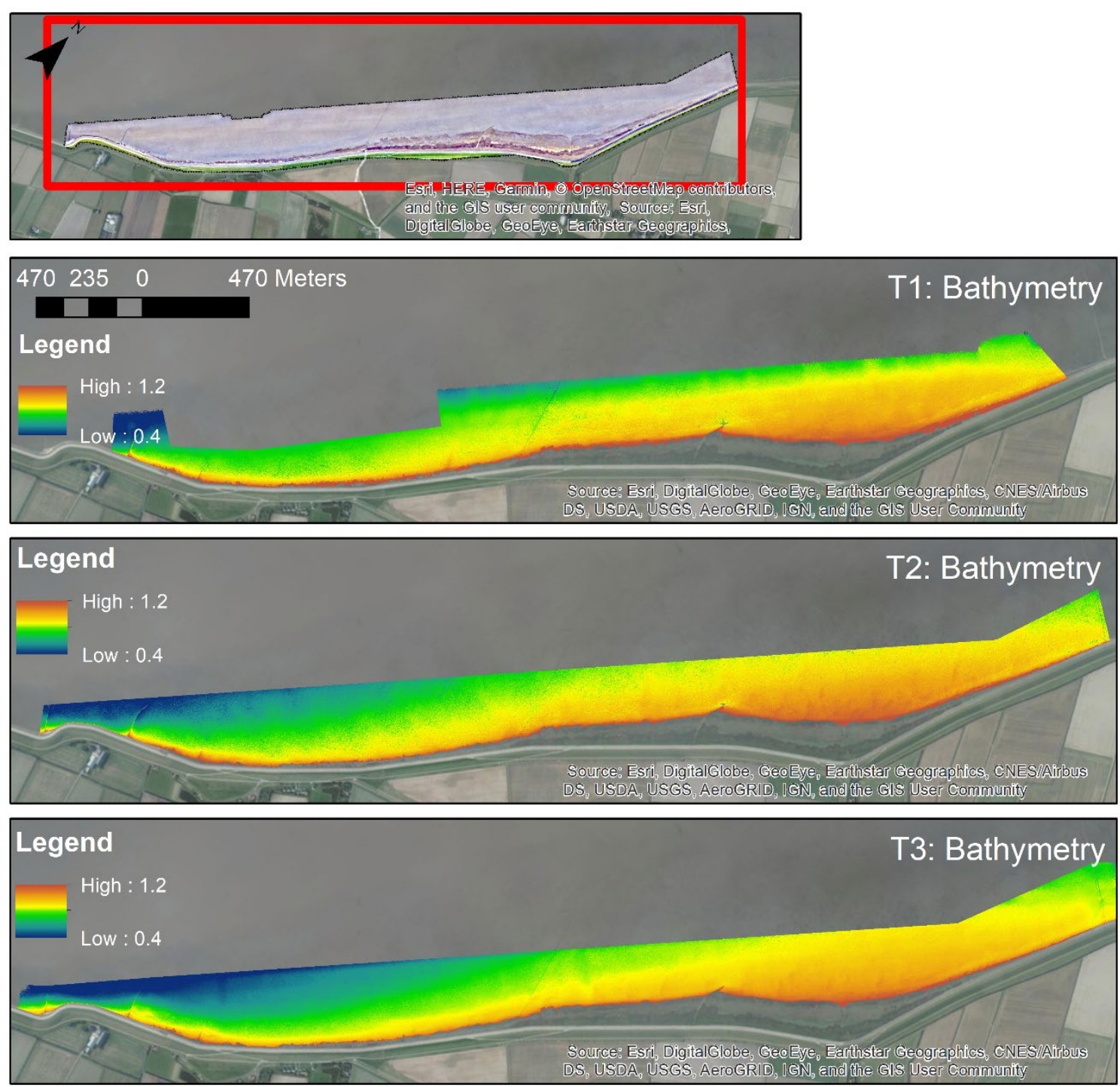

Figure 4-10. Measured bathymetry for T1, T2 and T3 measurements, presenting height levels between +1.2 and $+0.4 m$ NAP. Note that the surveyed area is slightly different in the different years. 

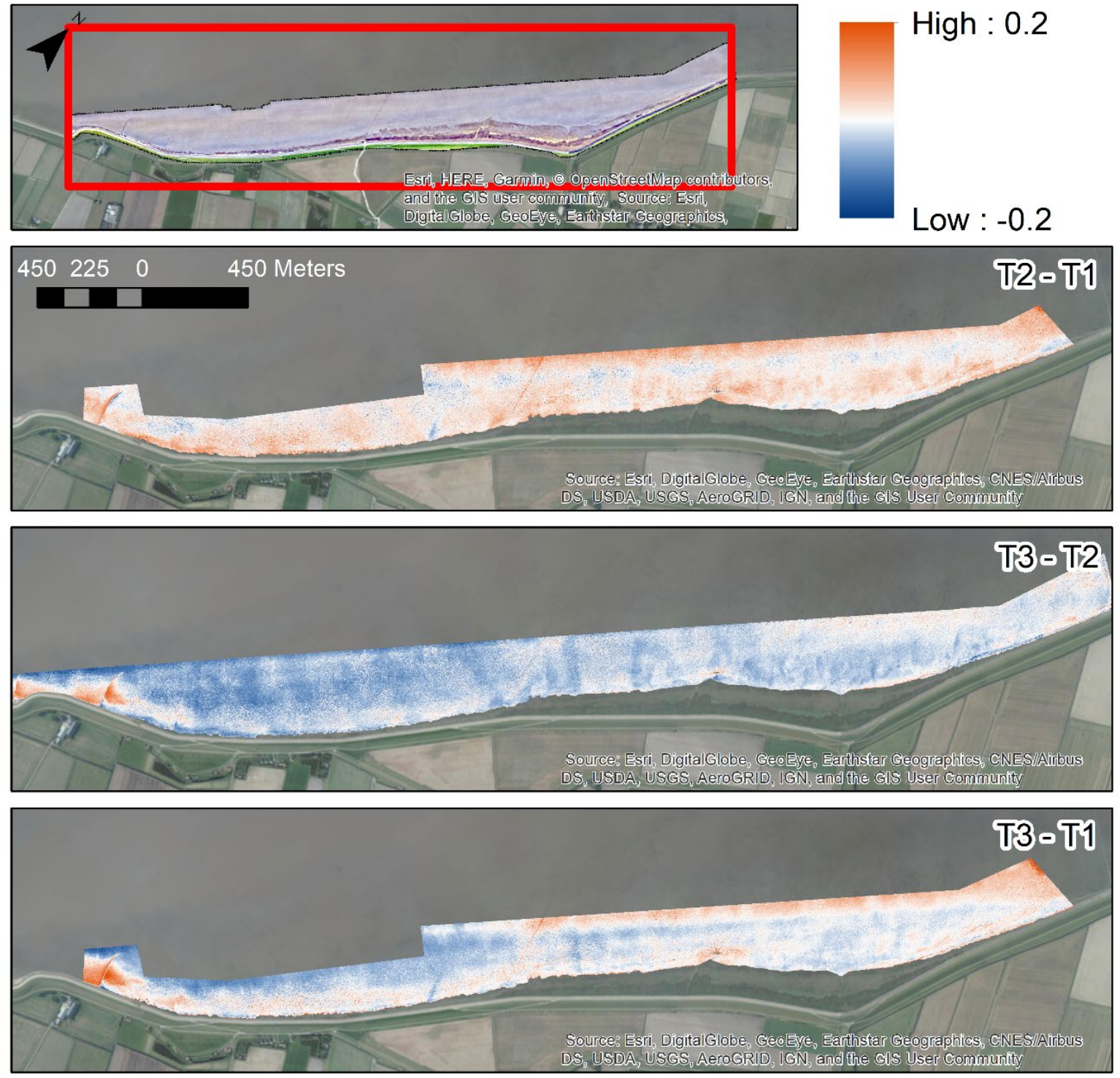

Figure 4-11.Difference plots between DEMs of the three different measurement: T2 minus T1 with a volumetric difference of $+27,200 \mathrm{~m}^{3}$, T3 minus T2 with a volumetric difference of $-43,200 \mathrm{~m}^{3}$ and T3 minus T1 with a volumetric difference of $-2,300 \mathrm{~m}^{3}$. The bathymetry varies in the order of $0.1 \mathrm{~m}$ between the different measurements. A clear accumulation of sediments up to $0.2 \mathrm{~m}$ can be observed in the southwest corner of the measurement area.

Remarkable is the accretion of sediments in the far southwest corner of the measurement area which is closest to the Mud motor location. Measurement T2 and T3 show an increase in bed levels at both sides of the groin structures in these areas (Figure 4-12). A relatively small bed level increase is observed between February and August 2017. This difference is measured at the end of the first disposal season. The measurement of August 2018 (T3, approximately 8 months after the final disposal of the second season) shows a larger accretion in this area. This is remarkable due to the presumption of a negative measurement error compared to the RTK-GNSS ground validation points in the other part of the measurement area. This pattern might therefore be an effect of the Mud motor. 

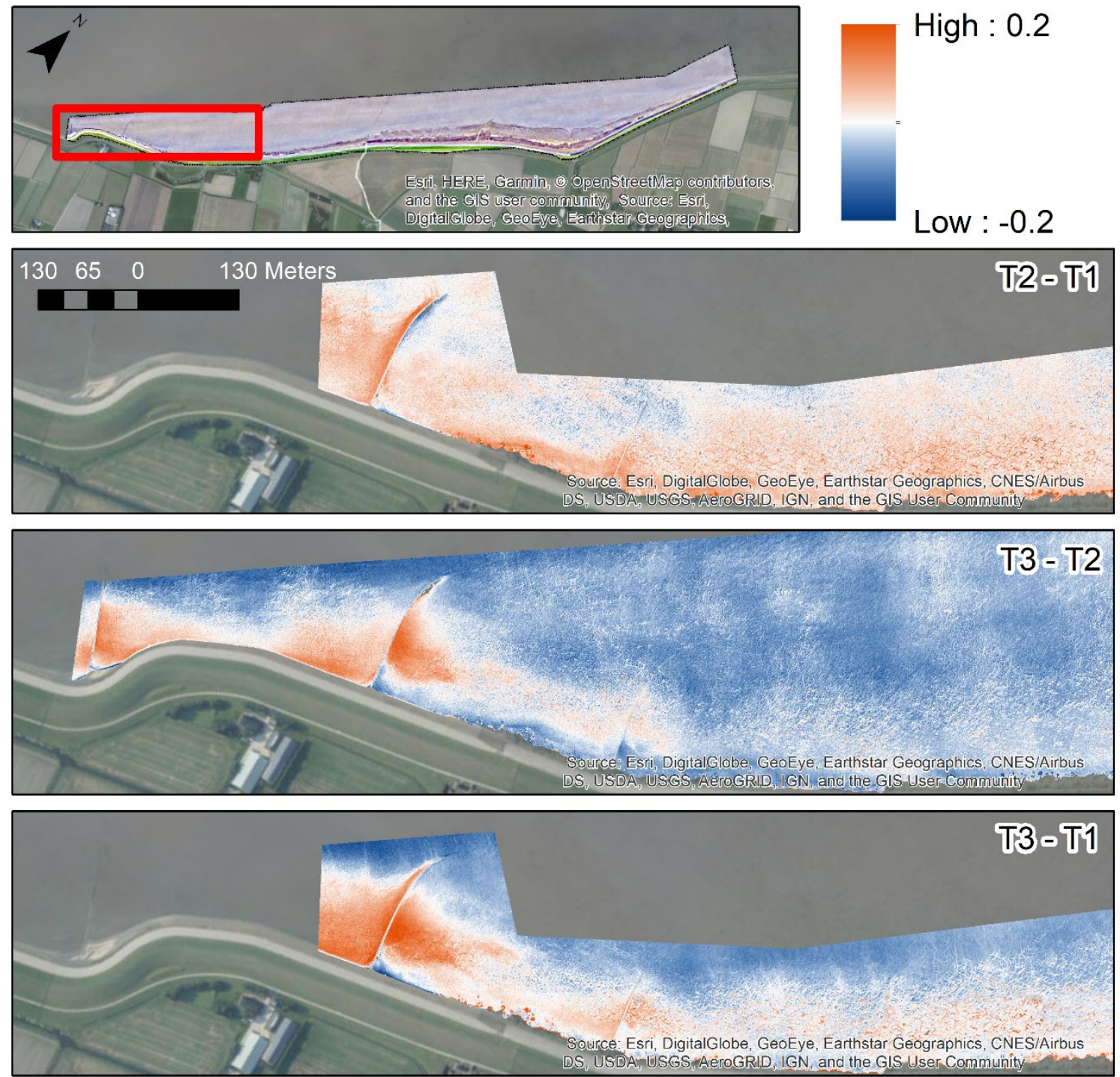

Figure 4-12.Difference plots between DEMs of the three measurements focused on the south-western part of the measurement area where most accumulation of sediments can be observed up to $0.2 \mathrm{~m}$.

The measurements show a slight overall bed level increase and a volume difference of about 27,000 $\mathrm{m}^{3}$ between $\mathrm{T} 1$ and T2. All measured bed level values are however small and in the same order as the accuracy of the measurement method. Between August 2017 (T2) and August 2018 (T3), a volume reduction of $43,000 \mathrm{~m}^{3}$ was measured. Over the entire period, only a very minor reduction in volume of $2,300 \mathrm{~m}^{3}$ is measured (comparing T3 and T1). Note that this value is not equal to the cumulative volumetric values given for T2-T1 and T3-T2 due to a difference in the spatial extent of the separate measurements. The sedimentation volume in the southwest corner of the measurement area is small compared to the disposed Mud Motor volumes: $1500 \mathrm{~m}^{3}$ for T2-T1 and $3400 \mathrm{~m}^{3}$ for T3-T2.

\section{Patterns of hummocks and hollows}

As the short-term bed level variations as observed by the SEDs are in the same order of magnitude as the bed irregularities of the hollows and hummocks, the bed level variations might be caused by migration of these patterns. The LiDAR scans can reveal how mobile these patterns are. During field campaigns, we observed that sometimes the bed irregularities are absent. The LiDAR scans also show sometimes larger and sometimes smaller irregularities, although this might be artificial. The depth of the small channels might namely be underestimated due to water that remains inside the channels during the measurements. This is a well-known issue for the LIDAR measurement technique [e.g. Vroom \& Beekhuizen (2015)]. 
The migration of the bedforms or gully patterns is studied by visualizing the channel locations of the three measurements in one overlay image (Figure 4-13). The middle plot of this figure shows all areas that are deeper than the average depth value in three partly transparent colours representing the three different measurements. For many channel areas, the three colours do nicely overlay (resulting in a dark green-grey colour) which indicates a stable channel pattern over the years.
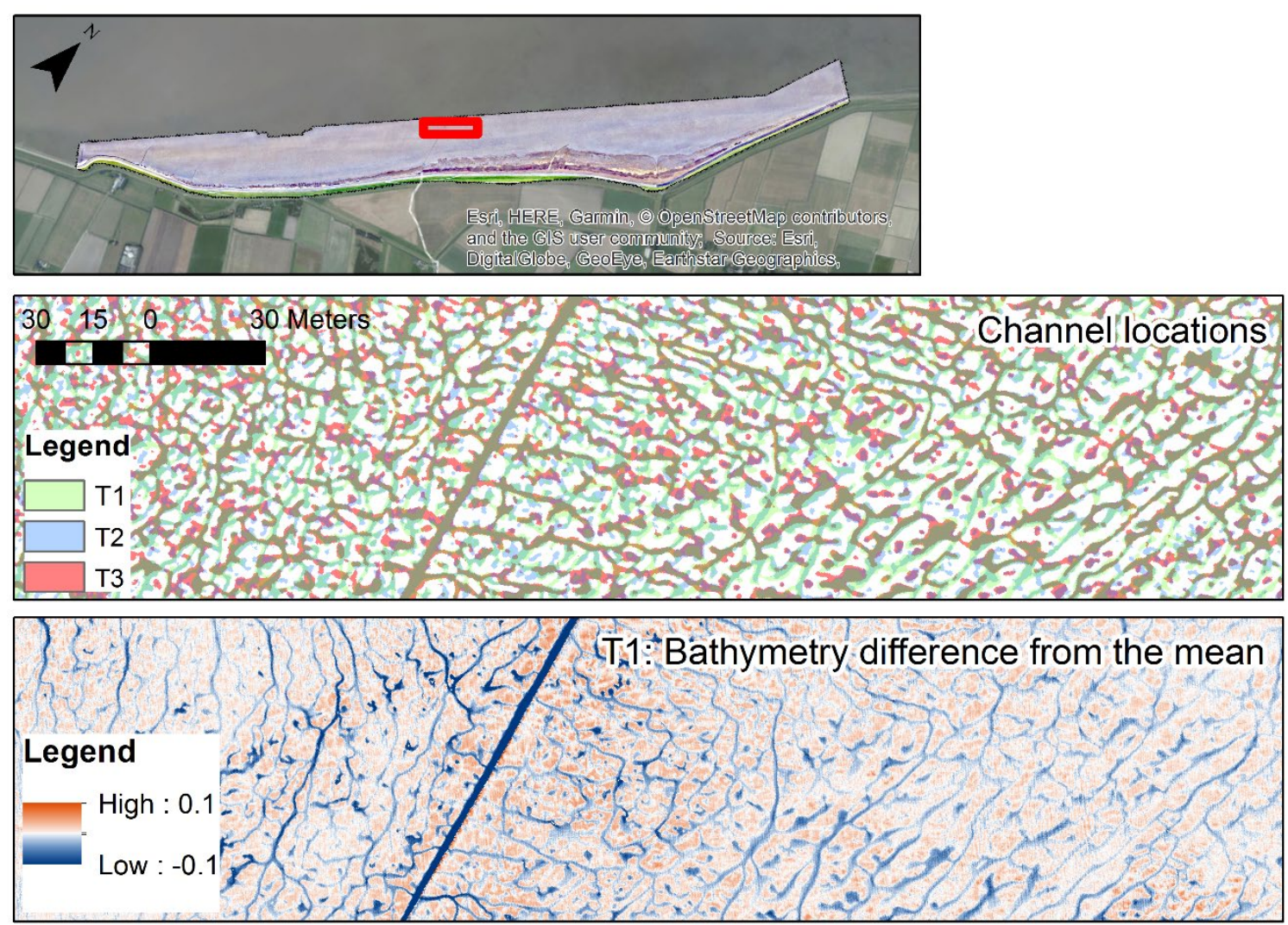

Figure 4-13. Locations of channels patterns represented by coloured patches that represent the three different measurements. Where the three colours overlap (resulting in a dark green-grey colour), the channels have not moved during the measurement period.

As the channel patterns are relatively stable, we conclude that the high dynamics as measured by the SEDs are not caused by channel pattern migration. The distinctness of the bedforms varies over time (Figure 4-14). Figure 4-15 shows the existence of channel patterns expressed in channel volume per square meter $\left[\mathrm{m}^{3} / \mathrm{m}^{2}\right]$ over the entire survey area. When this value is larger (more red colours), it represents a more distinct channel pattern while a white colour represents a flatter seabed. The most distinct channel pattern is observed for the T2 measurement. A remarkable difference is observed between this distinct channel pattern compared to measurement T3. Both measurements are taken in the summer season (August) which invalidates the fact that the channel existence is fully caused by changes on a seasonal timescale. Temporal absence of the channel patterns suggests filling of the hollows and gullies, either by soft mud or by water. From field campaigns we know that the bed irregularities may also disappear, so they are not always simply filled with water and that thick layers of soft mud may be present (section 4.2.1). It is therefore hypothesized that the disappearance or smoothing of the bed forms is mainly caused by presence of a blanket of soft mud. 

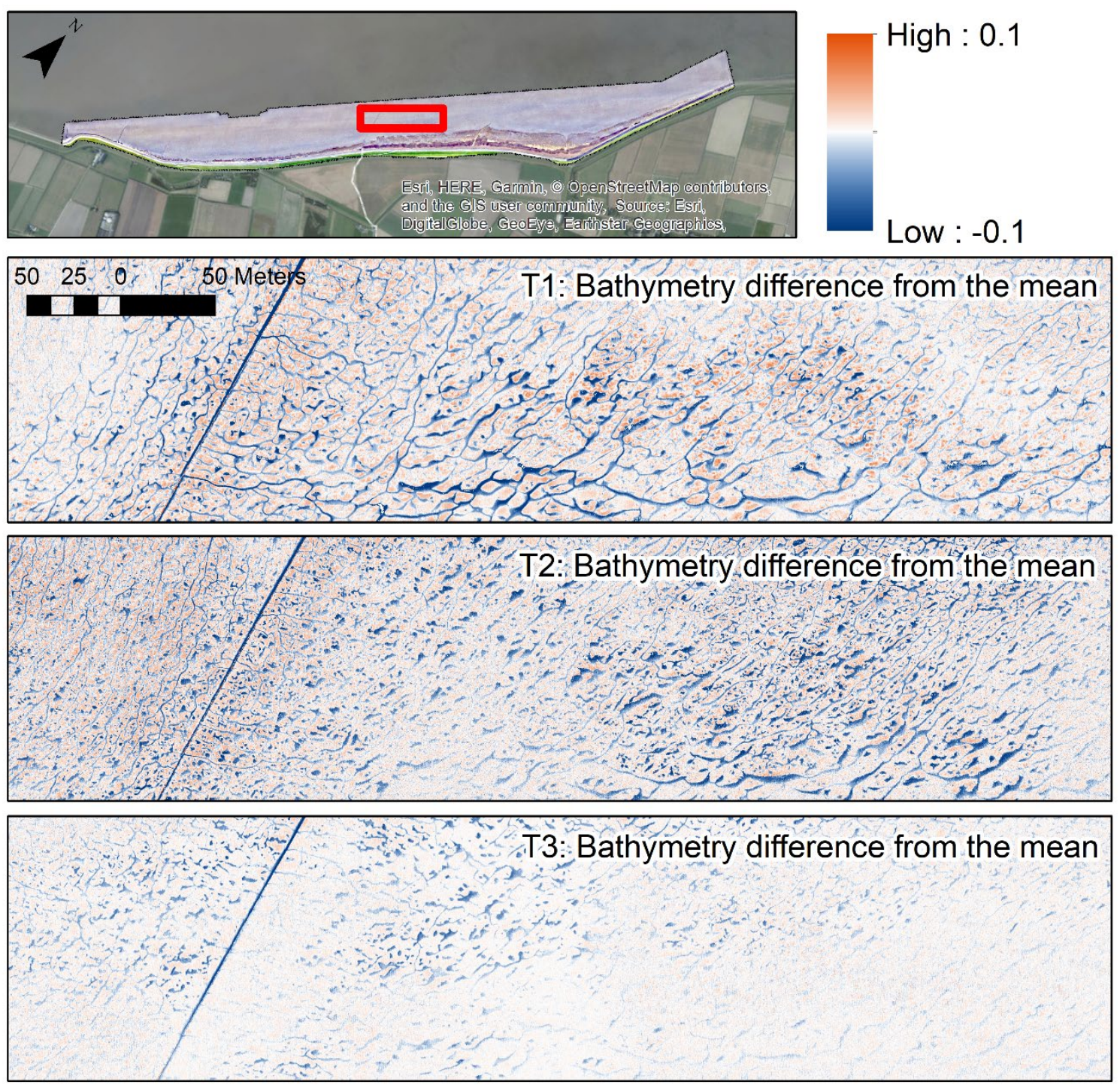

Figure 4-14.Relation between the channel pattern visibility and the bathymetry difference between measurement T2 and T1. In areas where the bed level has increased (red), the channel pattern becomes less visible which suggest the build-up of soft mud in these areas. In contrary, in case of a bed level decrease (blue), the existence of channels becomes more distinct. 


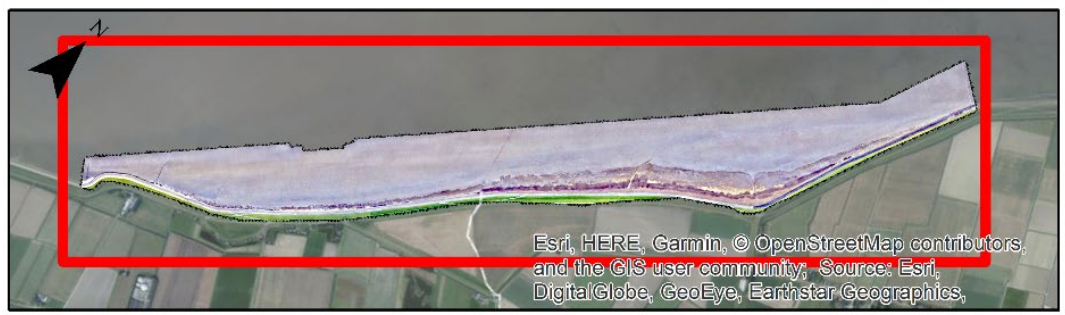

\section{Legend}
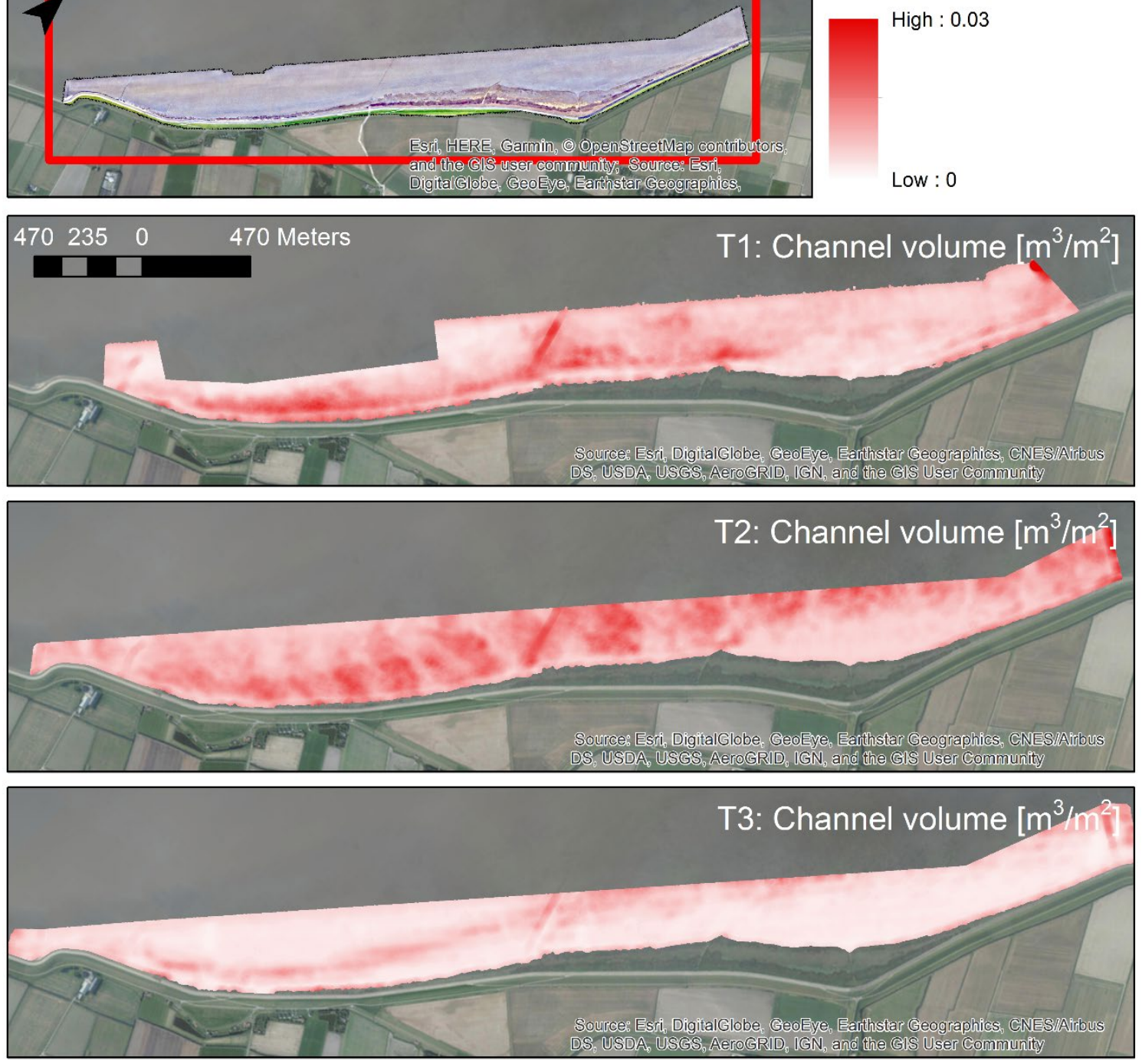

Figure 4-15. Existence of channel patterns expressed in channel volume per square meter $\left[\mathrm{m}^{3} / \mathrm{m}^{2}\right]$. Larger values (more red) indicate a more extinct distinct channel pattern. This figure shows a more distinct channel pattern in the T2 measurement while the pattern is least visible in the T3 measurement.

The existence of a channel pattern depends to a large extent on the bed level. This is shown in Figure 4-16, which shows the channel volume and the bathymetry of measurement T2. The most distinct channel patterns are observed in the areas with a bed level height between 0.7 and $1 \mathrm{~m}$ above NAP. 

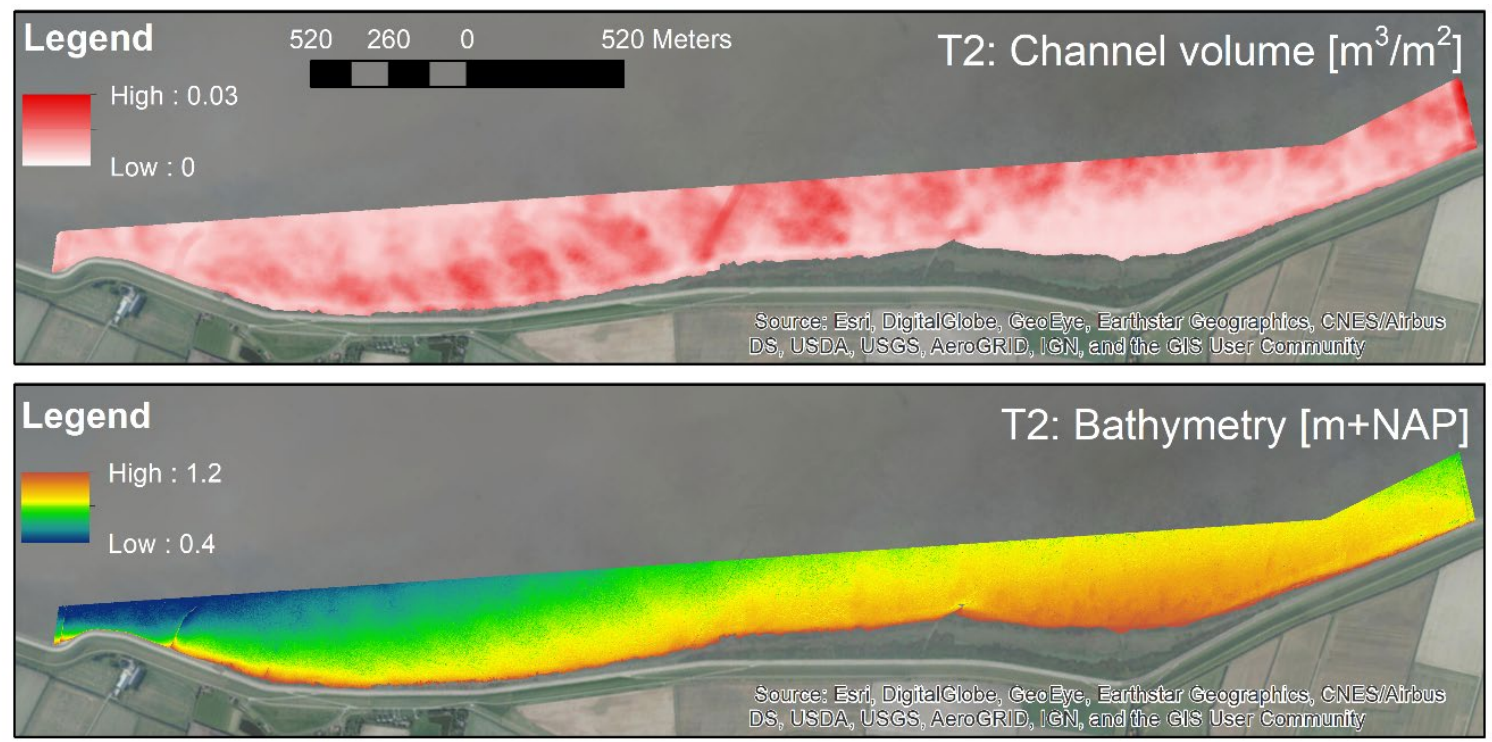

Figure 4-16 Existence of channel patterns expressed in channel volume per square meter $\left[\mathrm{m}^{3} / \mathrm{m}^{2}\right]$ (top) and bathymetry of measurement T2 (bottom). The channel areas strongly relate to the bathymetry. Channels are absent at the deeper and higher areas.

\subsubsection{Sediment transport in the Kimstergat}

\section{Methods}

Shipborne measurements in the tidal channel Kimstergat were carried out during three surveys in June 2015, April 2016, and October 2016 at locations C1 and C2 (Figure 4-2). The first two cruises were sailed before the start of the Mud Motor pilot, and the latter two during the pilot. During each cruise, suspended particulate matter (SPM) concentrations and current velocities were measured for 13 hours to calculate the residual SPM transport at two locations: close to the port of Harlingen and near the new disposal location. Current velocities were measured with two acoustic Doppler current profilers (ADCPs), one mounted on the ship, downward-facing, to profile the lower part of the water column, another one attached to a bottom lander (deployed nearby the ship), upward-facing, to profile the top part of the water column. The two data sets were combined, and, where necessary, interpolated to obtain current profiles covering the whole water column.

Vertical profiles of turbidity were obtained with optical backscatter sensors (OBS). The sensors were attached to a frame that was lowered from the stern of the ship in intervals of 15-20 minutes. Simultaneously, water samples with a Niskin bottle were taken and filtered over pre-weighed GFF filters to obtain the total suspended matter content. Water from the same Niskin bottle was sampled with another OBS in a dark box to obtain a linear regression between turbidity values and SPM concentration. The OBS in the box was then intercalibrated with the OBS on the frame to calculate the corresponding SPM concentration from the turbidity profiles. Additionally, the frame was equipped with sensors for salinity and temperature, and (only for the last cruise) with a Laser In-Situ Scattering and Transmissometer (LISST-200X, Sequoia Scientific Inc.) to measure the in-situ grain size distribution of the suspended matter. Details on the ship-based campaigns and an analysis of the data from the first thee cruises can be found in Schulz and Gerkema (2018).

\section{Results}

The tidal channel observations reveal a persistent flow near the bed in the ebb (seaward) direction (Figure 4-17A). Near surface, the flow is more variable (and larger), but typically directed in the flood (landward) direction. Schulz and Gerkema (2018) explain this vertical current structure with inverse estuarine circulation. The main fresh water source (the Kornwerderzand sluice) is located seaward of the observation stations. The horizontal salinity gradient drives a seaward directed near-bed pressure 
gradient, because salt water is denser than freshwater, resulting in an ebb-directed flow near bed, compensated by a flood-directed flow near the surface.
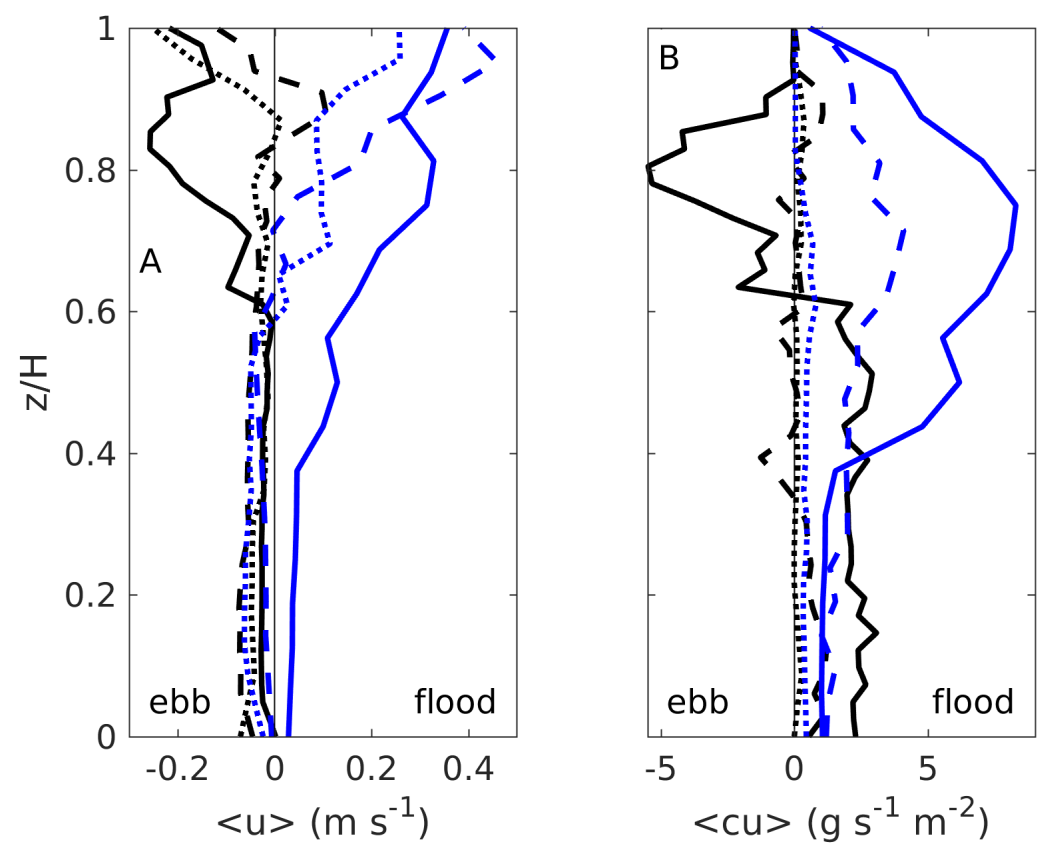

Figure 4-17. Tidally averaged residual current (A) and sediment flux (B) for station 1 (black) and 2 (blue) over depth. $\mathrm{Z} / \mathrm{H}=0$ indicates the bed; $\mathrm{Z} / \mathrm{H}=1$ is the water surface. Dashed, solid, and dotted lines refer to deployment (not detailed here). Figure from Schulz and Gerkema, 2018.

A near-bed residual flow usually results in a net transport direction in that same direction (as typically SSC near bed is higher than near-surface). However, the near-bed residual flux is in the flood direction (Figure 4-17B). Schulz and Gerkema (2018) explain this flood-dominant sediment transport through tidal asymmetry. The period of flood flow is shorter than the period of ebb flow, resulting in larger flood flow velocities than ebb flow velocities. Sediment transport increases non-linearly with the flow velocity, resulting in flood-dominant sediment transport. Closer to the water surface, transport is more variable, but typically also directed in the flood direction.

Although not explicitly addressed in Schulz and Gerkema (2018), residual landward transport is also generated by settling and scour lags (Van Straaten and Kuenen, 1957). Sediment particles are transported for a larger part of the tidal cycle in energetic environments than in low-energy environments. Flow velocities typically decrease from the tidal channel towards the shoal. During the flood tide (landward transport), a sediment particle is therefore resuspended earlier in the tidal cycle than during the subsequent ebb tide (in the seaward direction). Lag-driven transport may lead to landward transport of silt and clays in shallow channels despite ebb-dominant time asymmetries in opposite direction (Gatto et al., 2017), and therefore also likely to be an important component for landward transport in the Kimstergat channel.

Summarizing, the Kimstergat channel is flood-dominant in terms of sediment transport. Sediment available at both the old disposal location and the new disposal location will be transported towards the landward end of the Kimstergat channel by a combination of tidal asymmetry and lag effects.

\subsubsection{Role of wind driven flows at the tidal flats}

Role of wind on residual flow and sediment concentrations

More detailed observations in this area were collected by Irene Colosimo as part of her $\mathrm{PhD}$ thesis. Here, we restrict ourselves to a part of her dataset which concisely summarizes the mainly wind-related transport processes over the flats (presented in Colosimo et al. (in review)). 
Colosimo et al. observed that wind has a very large impact on residual transport over the flats for two reasons. First, wind drives a strong residual flow (Figure 4-18, with tide-averaged flow velocities up to $0.2 \mathrm{~m} / \mathrm{s}$ ). The direction of flow depends primarily on the wind direction, as the residual velocity during $\mathrm{SW}$ winds is in NE direction (most orange dots are positive). The residual flow velocity depends on the wind speed, but also on the magnitude of the tidal currents. Obviously, the residual current increases with the strength of the wind speed. However, Colosimo et al. also observed (and quantified) that the wind speed has a bigger impact on areas with a lower tidal current velocity (the upper mudflat, site $F_{H M}$ ) than on areas with a high tidal current velocity (the lower mudflat, site $F_{L M}$ ). In general, winds from the SW dominate, leading to a residual flow over the flats towards the NE.

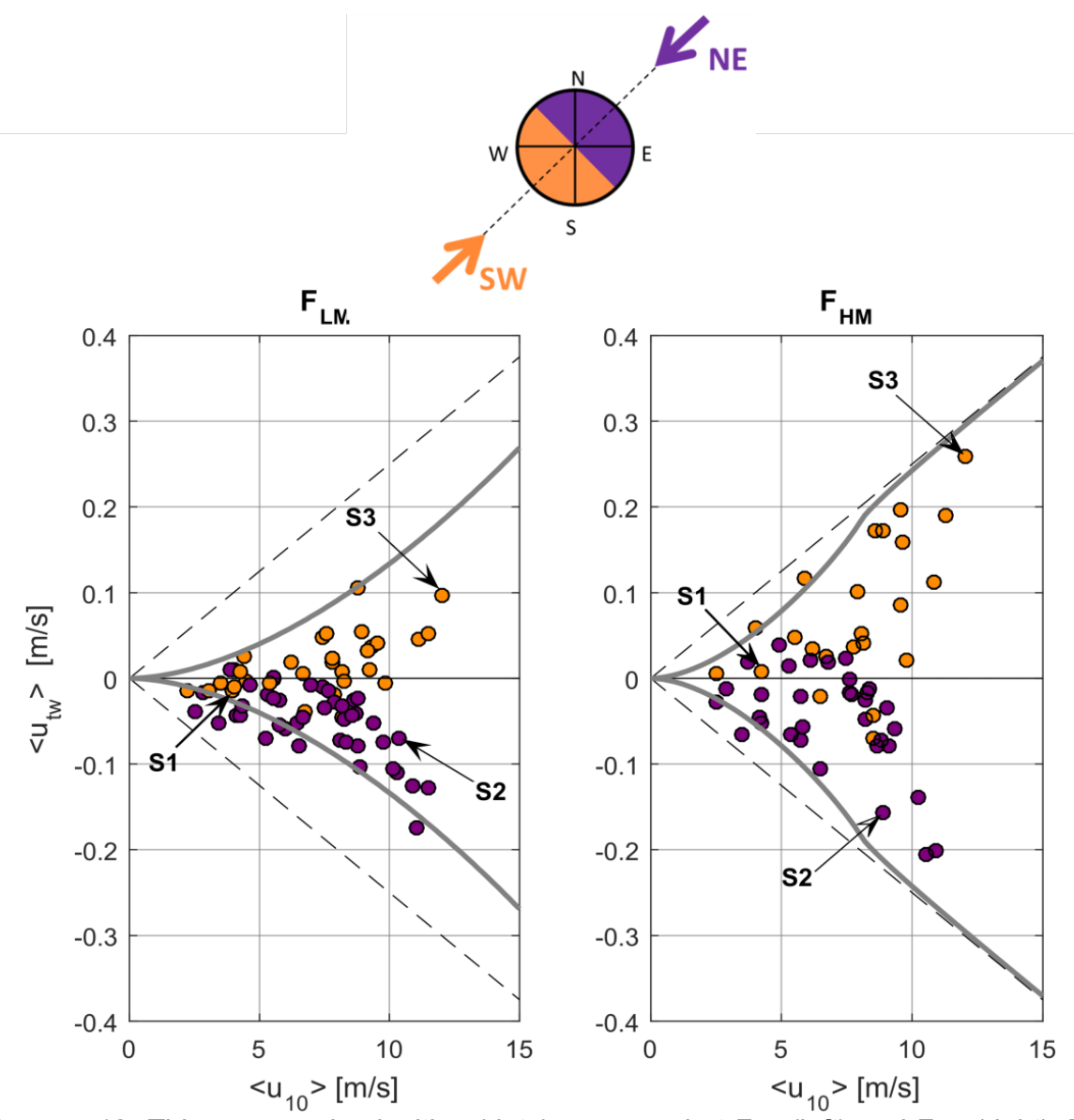

Figure 4-18. Tide-averaged velocities (dots) measured at $F_{L M}$ (left) and $F_{H M}$ (right). The colour indicates the wind direction (from SW or from NE); the x-axis the wind speed, and the $y$-axis the flow velocity magnitude and direction (positive = towards NE and negative = towards SW). The dashed lines indicate a flow velocity envelope assuming that wind velocity depends linearly on the wind stress; the solid grey line indicates the envelope including tide-wind interaction. S1, S2, and S3 represent three typical tides evaluated in more detail in Figure 4-19. Figure from Colosimo et al. (in review).

Secondly, the sediment concentration depends on wind conditions. The effect of wind on residual flow, the sediment concentration, and the residual flux is illustrated with three representative tides measured at the lower mudflat $\left(F_{L M}\right)$ in Figure 4-19. Herein, $S 1$ is a tide representing only tidal conditions, S2 represents a tide dominated by winds from the NE, and $\mathrm{S} 3$ a tide dominated by winds from the SW. In absence of wind (S1), the tidal current and the sediment concentration are both fairly symmetric, and as a result of this symmetry the residual sediment flux is low and in flood direction. During winds from the SW (S3), the sediment concentrations are slightly higher during flood $(\sim 2 \mathrm{~g} / \mathrm{l})$ than during ebb $(\sim 1$ $\mathrm{g} / \mathrm{l})$. Combined with a residual flow from the SW to the NE, this leads to a residual flux towards the NE which is slightly larger than in absence of wind. However, during winds from the NE (S2), the sediment concentration during the ebb $(\sim 10 \mathrm{~g} / \mathrm{l})$ is much higher than during the flood $(2 \mathrm{~g} / \mathrm{l})$. The residual flux during tide S2 is 5 times larger than the flux during S3 (despite the winds being stronger during S3 see Figure 4-18). This is explained in the next section. 
FLM
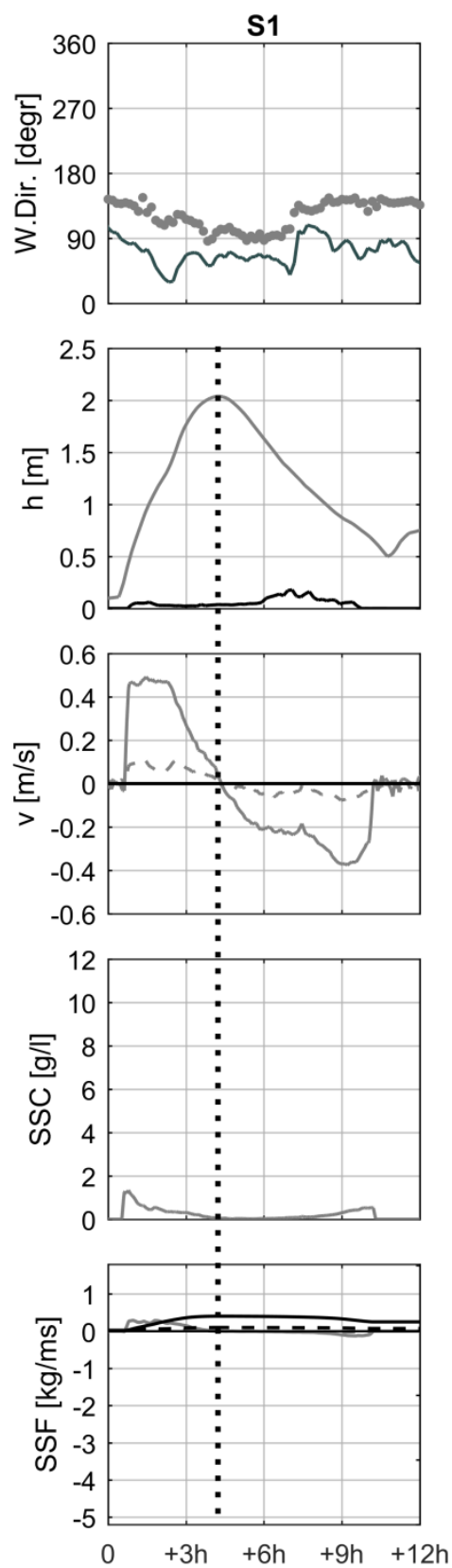

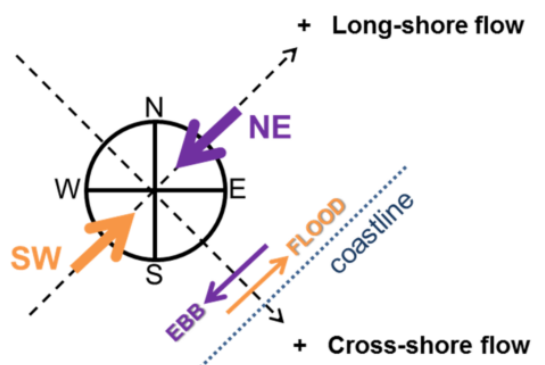

S2
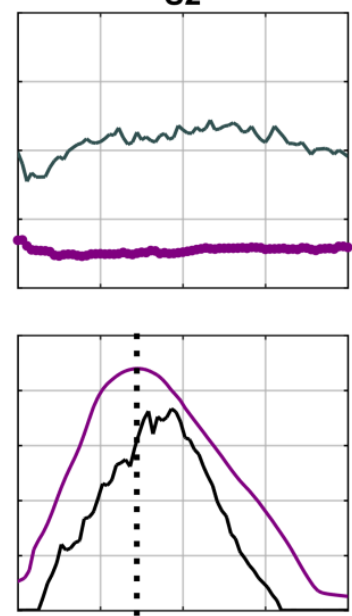

:
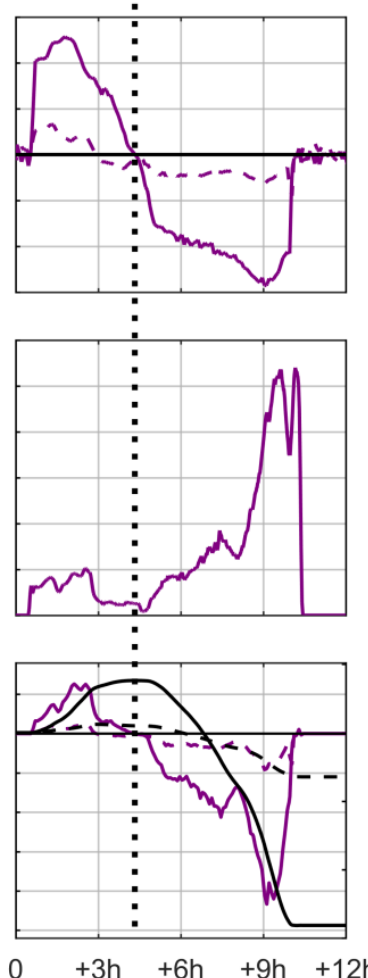

S3
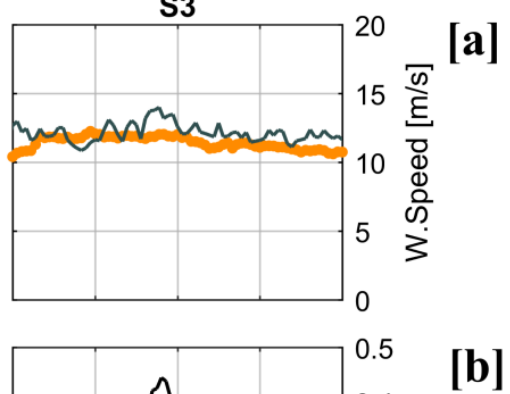

[b]

[a]

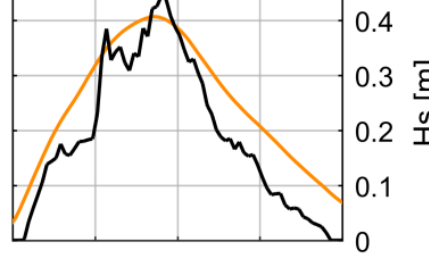

写

足

[c]
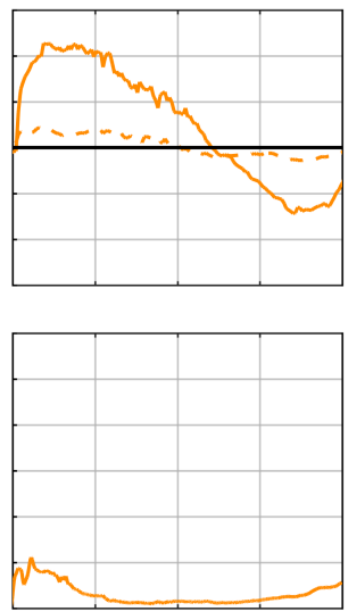

[d]

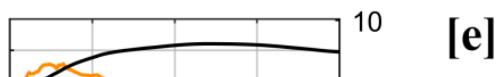

[e]

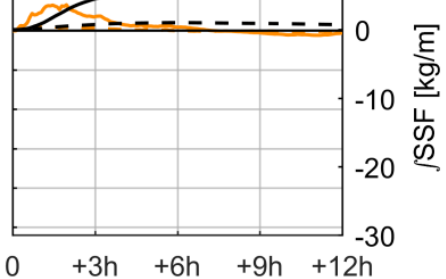

Figure 4-19. Intra-tidal variation at the lower mudflat $\left(F_{L M}\right)$ (a) Wind direction (markers; left axis) and speed (solid line; right axis); (b) Water depth (coloured line; left axis) and significant wave height (black solid line; right axis); (c) Flow velocity (positive in the flood direction) in the long-shore direction (solid line) and cross-shore direction (dashed line); (d) Suspended Sediment Concentration; (e) Suspended Sediment Flux (coloured line; left axis) and timeintegrated Suspended Sediment Flux (black line) in the long-shore direction (solid line) and cross-shore direction (dashed line) for three wind scenarios: S1 (low wind speed; left panels), S2 (wind from the NE; middle panels) and S3 (wind from the SW; right panels). Figure from Colosimo et al. (in review). 


\section{Residual sediment fluxes}

During conditions without wind or winds from the SW, sediment is transported from the Wadden Sea into the Kimstergat channel. The sediment transport direction is computed by a sediment flux SSF by multiplying the measured flow velocity, water depth, and sediment concentration (left axis in Figure 4-20b and c). However, the response of the sediment flux to wind events is better illustrated with the residual sediment flux $f_{\mathrm{t}}$ SSF (right axis in Figure 4-20b and $\mathrm{c}$ ). An increase in $f_{\mathrm{t}}$ SSF indicates transport to the NE, a decrease transport to the SW.
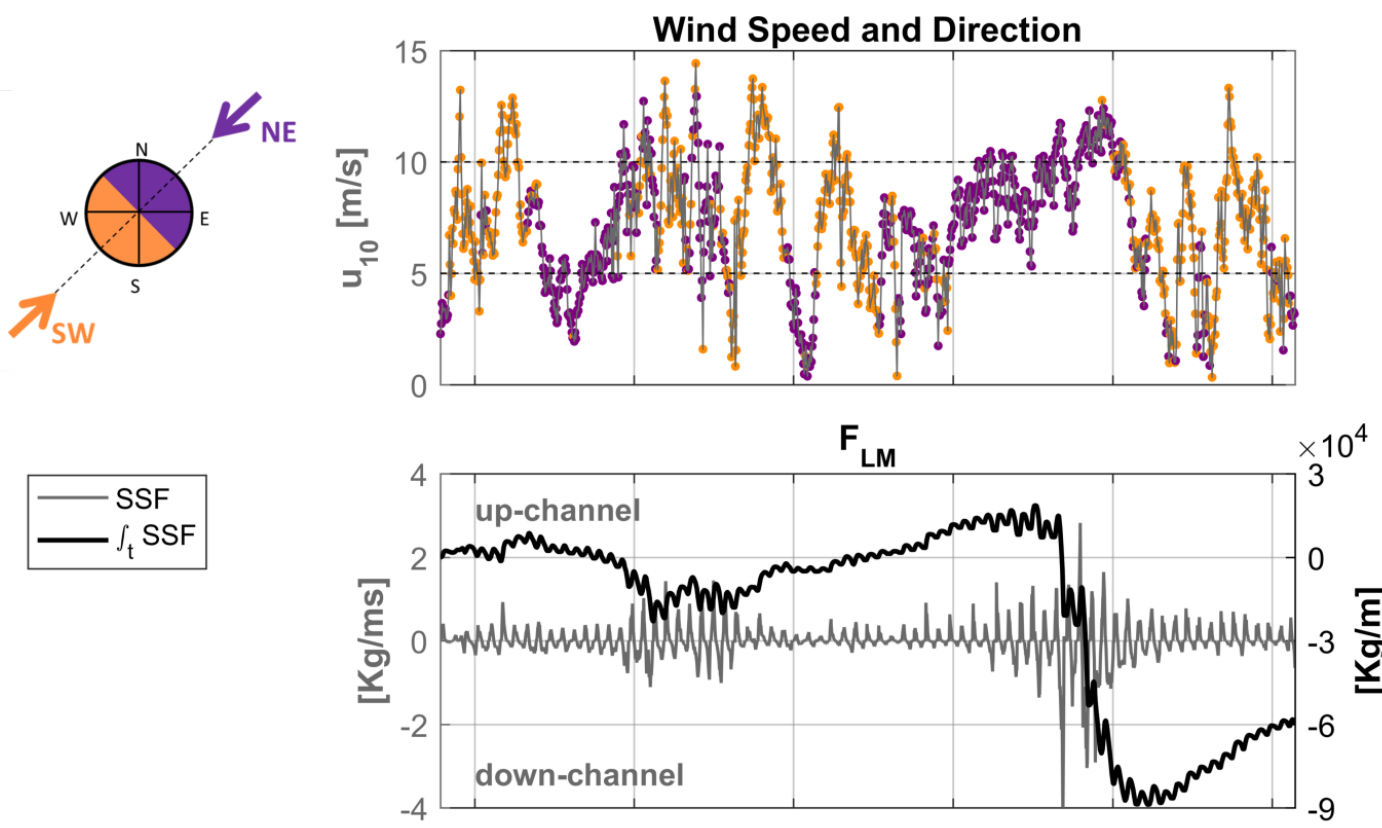

[a]
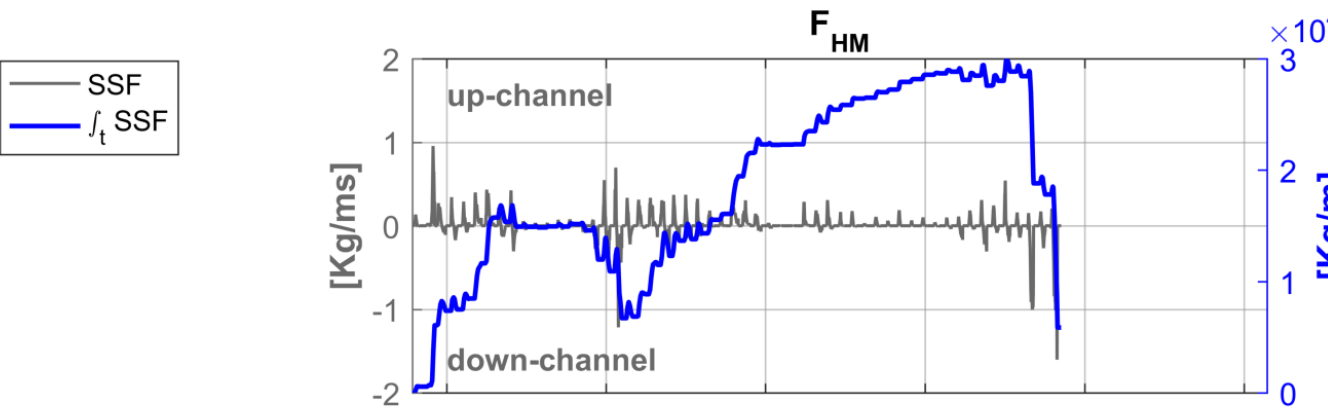

[c]
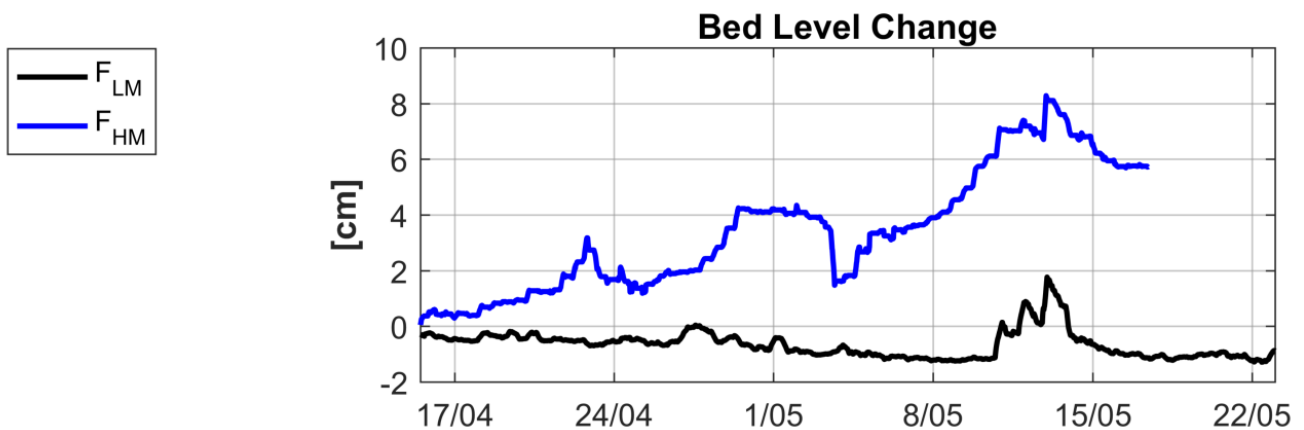

[d]

Figure 4-20. Wind speed (u10) and direction (colour of the markers) [a]; residual transport (instantaneous in grey, cumulative in black) at FLM [b] and FHM [c]; and bed level change at FLM and FHM [d]. Positive fluxes are towards the NE, negative fluxes are towards the SW. Figure from Colosimo et al. (in review).

This figure reveals the following:

- At the lower frame, sediment is mostly transported to the NE from 27 April to 12 May and 16 to 22 May. During these periods, the wind was predominantly from the SW, although some events with fairly weak NE winds occurred (6 to 12 May). Fairly strong SW from 16 to 20 April did not lead to significant NE transport. 
- Also at the lower frame, sediment is transported to the SW during winds from the NW (21-25 April, 13-15 May). During the NW wind event from 13 to 15 May, more sediment is transported to the SW than the cumulative NE transport during the whole measurement period. The wind speed during this event was not larger than several SW wind events, indicating the more sediment is available for transport NE of the measurement frames.

- The pattern is fairly similar for the higher frame, with some minor deviations. The SW wind from 16 to 20 April did lead to substantial transport to the NE (when transport at the lower frame was small) and during the subsequent NE wind event (21-25 April) residual transport was negligible (when transport at the lower frame was substantial). The measurement frame broke down during the 13-15 May event, so it is difficult to compare the impact of this event in detail.

- Until the 13-15 May event, the NW transport was comparable for both frames $\left(\sim 210^{4} \mathrm{~kg} / \mathrm{m}\right.$ at the lower frame, $\sim 310^{4} \mathrm{~kg} / \mathrm{m}$ at the higher frame).

- During the measurement period net deposition prevailed at the higher mudflat, whereas little deposition (or even erosion) was observed at the lower mudflat. Deposition at the higher mudflat occurred during SW wind events.

It is hypothesized that substantial amounts of sediment are transported from the channel to the shoals during SW wind events. This sediment is deposited at the higher mudflat but probably also east of the study area (likely on the local tidal divide, the 'Terschellinger Wad' - see Figure 2-1). During winds from the NE, large amounts of this freshly deposited sediment are remobilised and transported back towards the SW. This may even occur during fairly low wind velocities. For the Mud Motor, this means that disposal can best be done during SW winds, although the flow in the Kimstergat is less sensitive to wind forcing than flow at the tidal flat. In addition, this reduces the possibilities for disposal at the Mud Motor (MM) disposal location further as another restriction for disposal is added. Favourable conditions after disposal should last for a period of days to weeks to have sediment transport in the right direction and consolidation to generate strength against erosion, which makes it difficult to anticipate to these conditions.

\subsection{Vegetation dynamics}

\subsubsection{Aerial photography}

\section{Methods}

Orthogonal aerial photos were taken with an UAV (drone). The resolution of the aerial photographs of 2015, 2016, 2017 and 2018 was around $0.1 \mathrm{~mm}$. From these aerial photographs different vegetation types were distinguished, and the changes in area of the different vegetation types (pioneer zone / low marsh, reed and sea couch) calculated. The classification of the different vegetation types was done automatically by creating a Random Forest model. The error of the classification differed between years (2015: $6 \%, 2016: 25 \%, 2017: 4 \%, 2018: 14 \%)$. Differences in the timing of the orthophoto and differences in weather conditions (such as a drought period) resulted in different colour intensities of the different vegetation types which resulted in more / less errors. The drought in the summer of 2018 caused problems with the classification of the different vegetation types and therefore we could only classify between non-vegetated, vegetated with reed and vegetated with either pioneer zone, low marsh and high marsh (with Elytrigia atherica).

\section{Vegetation expansion}

Results of the UAV orthophotos taken between August and October each year showed that the area of salt marsh vegetation grew from 28.2 ha to 29.9 ha prior to the Mud Motor pilot between September 2015 and September 2016 (Table 4-4). The salt marsh area lost 3.5 ha between September 2016 and August 2017, which was the first winter of the Mud Motor pilot. The area then increased with 1.5 ha to 27.9 ha between August 2017 and August 2018, during the second winter of the Mud Motor pilot (Figure 4-21-24). 
Table 4-4. Total salt-marsh area (in ha) and for the three different vegetation zones. Weather conditions are given for the main growing season between April and August for each year. *In 2018 it was not possible to distinguish between pioneer / low marsh and Elytrigia atherica, so we estimated the Sea Couch from previous years.

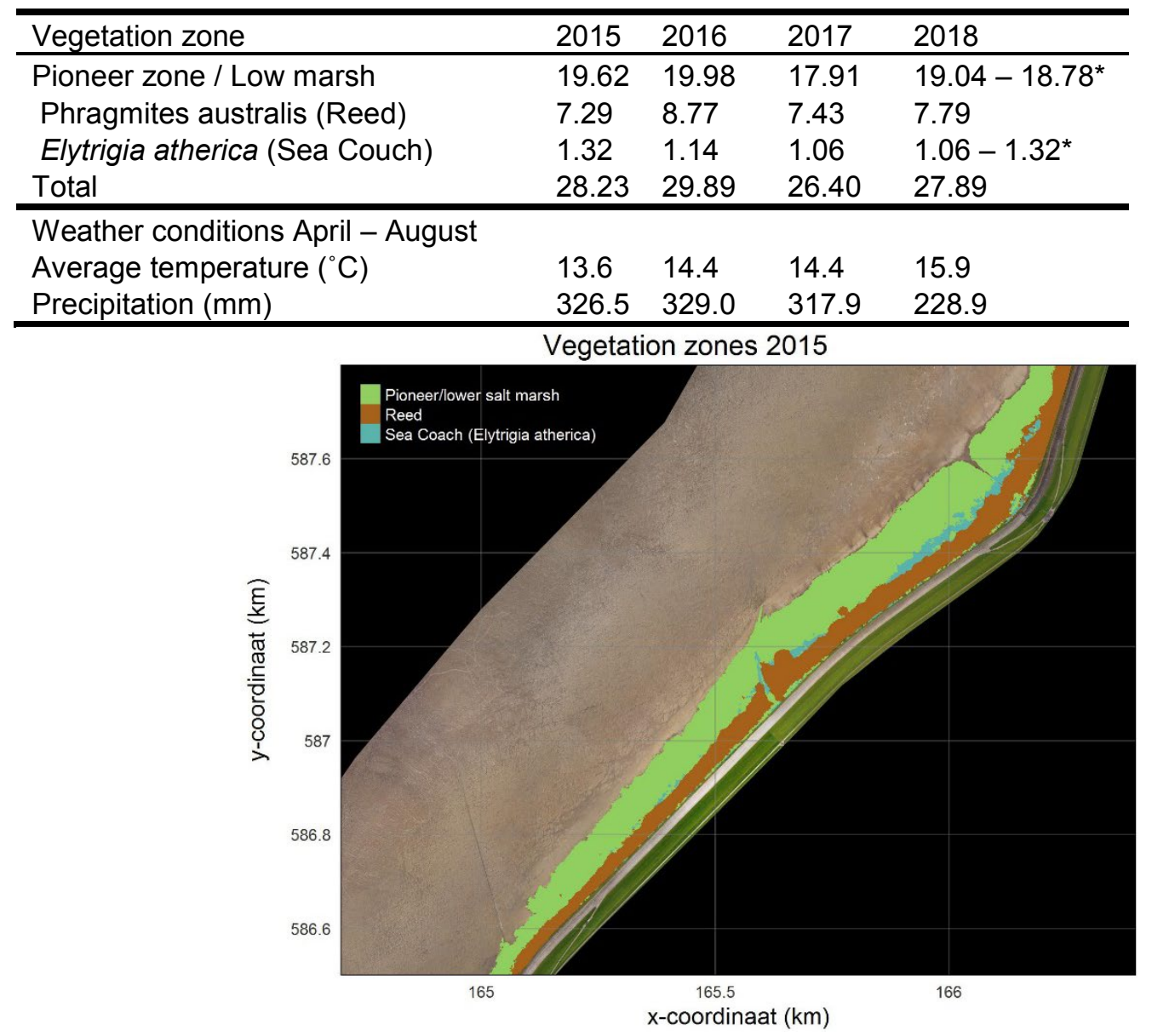

Figure 4-21. Overview of the location of the different vegetation types on the Mud Motor site for 2015

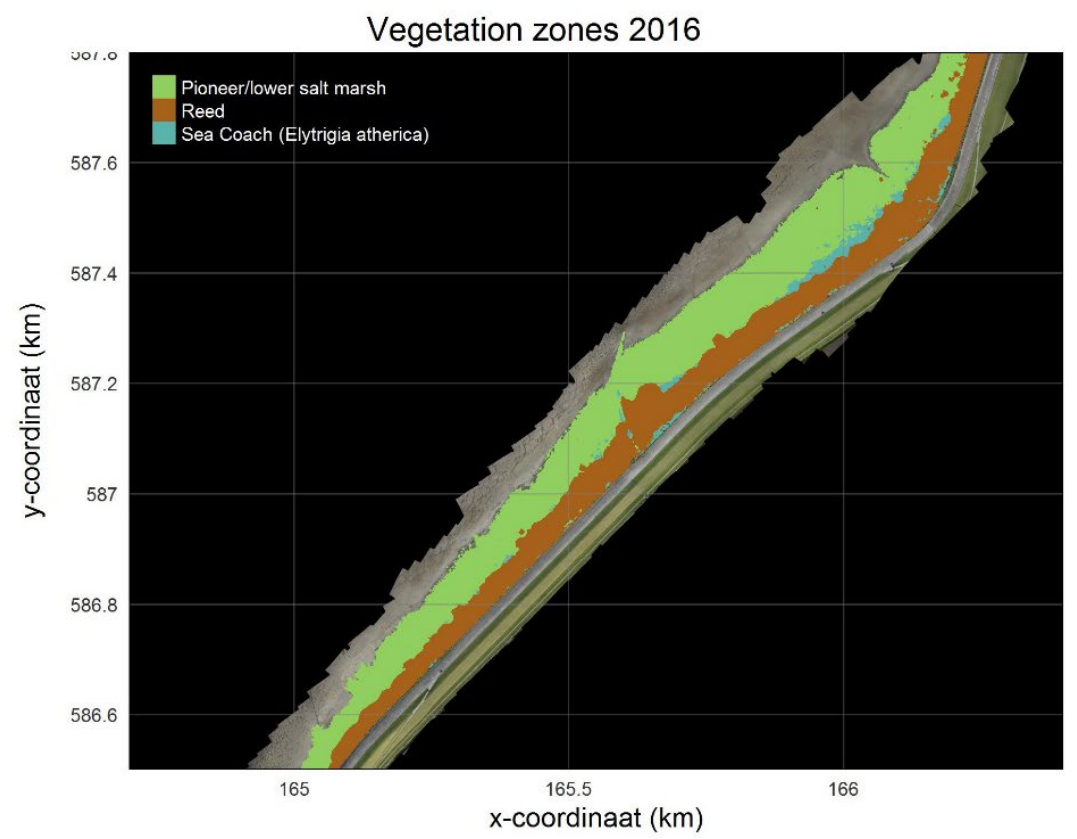

Figure 4-22. Overview of the location of the different vegetation types on the Mud Motor site for 2016. 


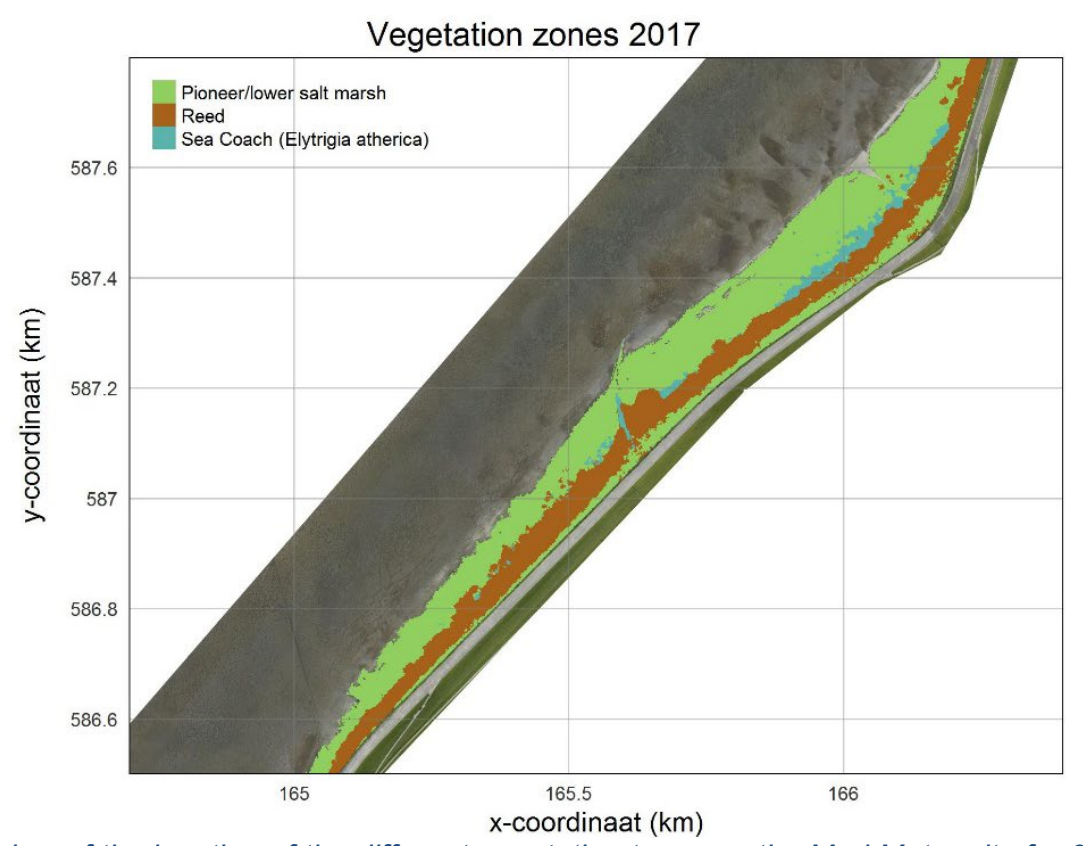

Figure 4-23. Overview of the location of the different vegetation types on the Mud Motor site for 2017.

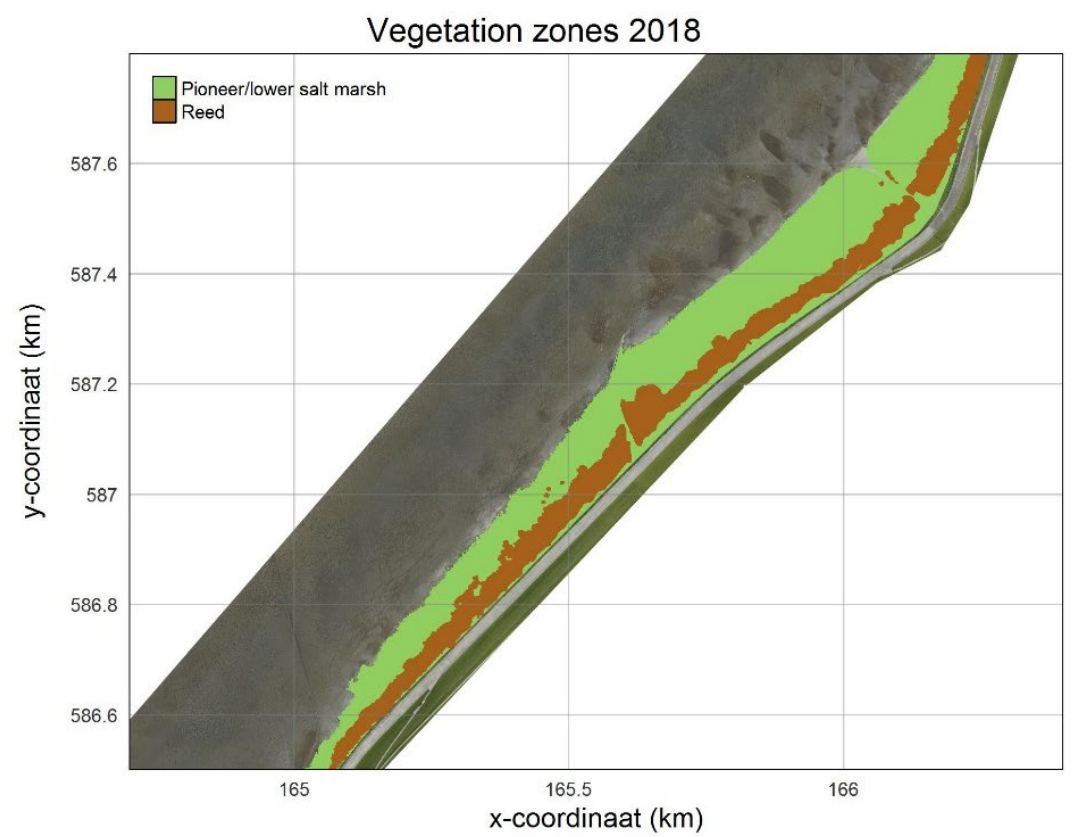

Figure 4-24. Overview of the location of the different vegetation types on the Mud Motor site for 2018. In 2018 it was not possible to distinguish the Eltrigia atherica vegetation from the pioneer / lower salt marsh vegetation.

\subsubsection{Vegetation development}

\section{Methods}

Yearly, in situ measurements of vegetation diversity and density were performed at permanent quadrats (PQ) located adjacent to the salt marsh SEB-stations (Figure 4-1) on both the Mud Motor site and the control site. Each plot was $2 \mathrm{~m} \times 2 \mathrm{~m}$ and vegetation was estimated using the decimal scale of Londo (Londo 1976). The vegetation development in these PQ-plots for multiple years allowed us to compare the study area to a control salt marsh (Zwarte Haan) in order to determine the expansion rate and marsh stability. The presence and density of the plant species were used to determine the salt marsh vegetation zone for each PQ-plot. The PQs were separated into different salt marsh vegetation zones by using the Dutch SALT97 vegetation classification for salt marshes (De Jong et al. 1998). For each different vegetation zone, the sedimentation and vegetation development were calculated. 


\section{Vegetation development}

In the PQs the vegetation cover increased slightly between 2016 and 2018, whereas the vegetation cover in the PQs at the control site was slightly lower in 2017, but increased again in 2018 (Figure 4-25). The increase in cover was most prominent in the $P Q s$ were vegetation was already present, as there was no increase in number of $P Q s$ with pioneer vegetation. Neither was there accelerated succession in the vegetated plots within the short time period of three years. For the control site there was no change in cover except for the pioneer zone that decreased in cover (Figure 4-26).

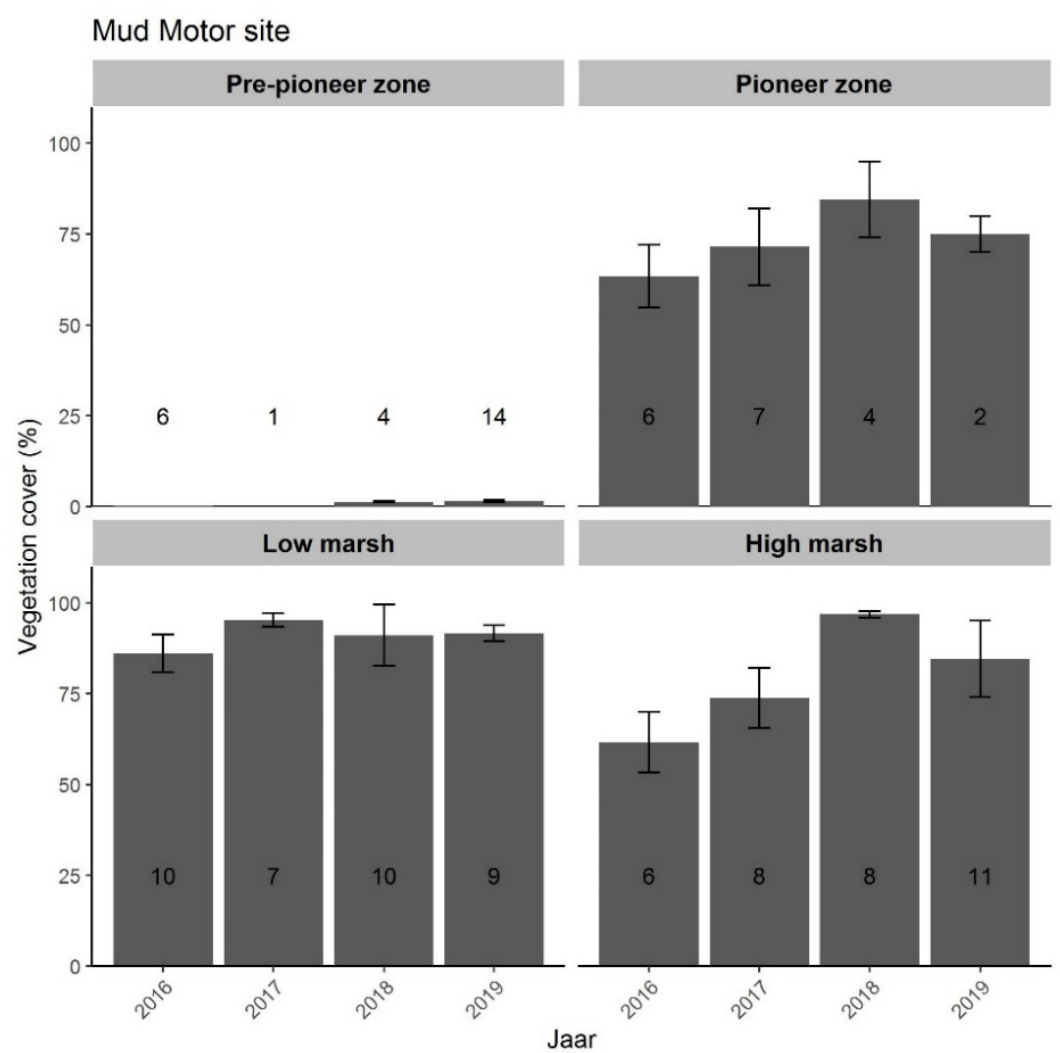

Figure 4-25. Average vegetation cover with standard error for each year in each vegetation zone of the Mud Motor site. The numbers indicate the number of plots for each vegetation zone. 


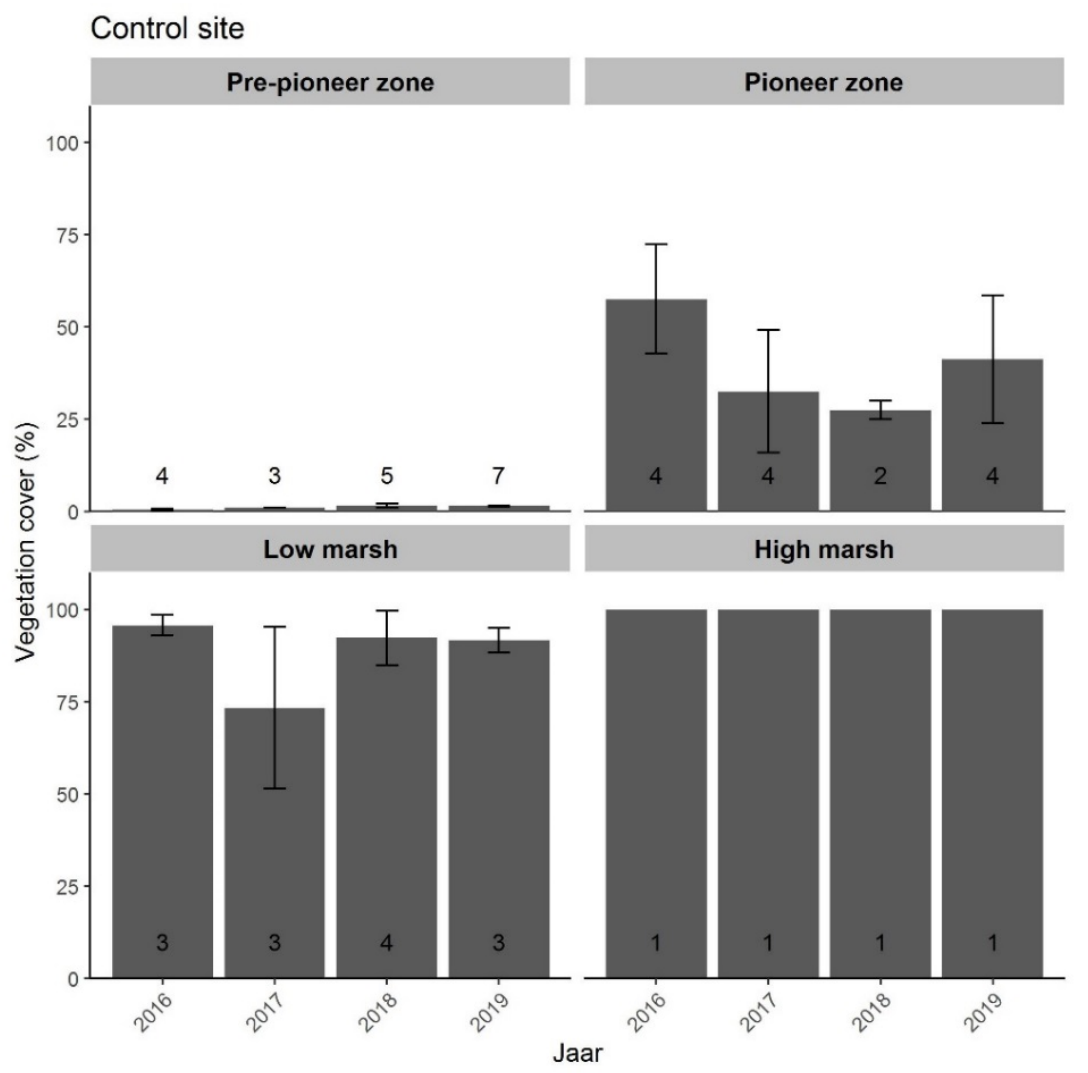

Figure 4-26. The average vegetation cover with standard error for each year in each vegetation zone of the Control site. The numbers indicate the number of plots for each vegetation zone.

Both the salt marshes at the Mud Motor site and control site were not species rich, the most diverse plot had 11 plant species (Table 4-5). The annual pioneer species Salicornia europaea increased in cover in 2017, but decreased again in 2018. In 2019 the cover was similar, but S. europaea occurred in more PQ's, suggesting expansion. The other perennial pioneer species Spartina anglica, had similar cover in 2016 and 2017, but decreased in cover in 2018 (Table 4-5). The low marsh vegetation was dominated by Aster tripolium in 2016, however this plant reduced in cover and was partly replaced by Suaeda maritima and Puccinellia maritima in 2017 and 2018. In 2019, S. maritima expanded and occurred in much more PQ's, and was even found in the pioneer zone. The plant species from the high marsh all had a higher cover, except Atriplex prostata. The control site showed similar changes in plant species cover, except that Phragmites australis was almost not present in the PQs. Furthermore, S. europaea had the highest cover in 2016 and its cover decreased by $15 \%$ in 2017 and 2018, while for the Mud Motor site the highest cover was in 2017. Similar in the Mud Motor site, S. europaea increased in 2019, by having a higher cover and occurring in more PQ's. From the aerial photographs we found that the salt marsh area was largest in 2016. This indicates that spring 2016 had optimal conditions for vegetation expansion. However, the pioneer species had a lower cover that year in the $P Q$, indicating the vegetation development of PQs does not always reflect the vegetation development of the entire salt marsh.

Table 4-5. Species richness $(R)$ and average cover (\%) of the most common species for each year and site $(M M=$ Mud Motor, $C=$ Control). Between brackets is the number of PQs in which the species were found. The most common species are the plant species with more than $1 \%$ cover.

\begin{tabular}{|c|c|c|c|c|c|c|c|c|c|c|}
\hline Site & Year & $\mathrm{R}$ & $\begin{array}{l}\text { Pioneer sp } \\
\text { Salicornia } \\
\text { europaea }\end{array}$ & $\begin{array}{l}\text { Sies } \\
\text { Spartina } \\
\text { anglica }\end{array}$ & $\begin{array}{l}\text { Low salt } r \\
\text { Suaeda } \\
\text { maritima }\end{array}$ & $\begin{array}{l}\text { arsh specie } \\
\text { Aster } \\
\text { tripolium }\end{array}$ & $\begin{array}{l}\text { Puccinellia } \\
\text { maritima }\end{array}$ & $\begin{array}{l}\text { High salt } \\
\text { Atriplex } \\
\text { prostata }\end{array}$ & $\begin{array}{c}\text { rsh species } \\
\text { Elytrigia } \\
\text { atherica }\end{array}$ & $\begin{array}{l}\text { Phragmites } \\
\text { australis }\end{array}$ \\
\hline MM & 2016 & 10 & $10.7(12)$ & $18.8(14)$ & $16.8(11)$ & 33.7 (16) & $15.0(10)$ & $1.6(10)$ & $45.3(2)$ & $80.1(6)$ \\
\hline MM & 2017 & 9 & $14.8(14)$ & $21.8(15)$ & 26.5 (14) & $9.8(18)$ & $36.8(8)$ & $15.9(13)$ & 97.5 (1) & $70.0(7)$ \\
\hline MM & 2018 & 11 & $8.4(17)$ & 9.7 (15) & $30.1(17)$ & $8.6(14)$ & $37.1(11)$ & $17.5(17)$ & 70.0 (1) & $70.0(7)$ \\
\hline
\end{tabular}




\begin{tabular}{ll|l|ll|lll|lll} 
MM & 2019 & 9 & $8.35(25)$ & $9.35(15)$ & $16.5(27)$ & $2.32(17)$ & $20.55(11)$ & $24.09(16)$ & $97.5(1)$ & $78.21(7)$ \\
\hline $\mathrm{C}$ & 2016 & 9 & $22.4(10)$ & $14.3(6)$ & $13.3(4)$ & $35.5(5)$ & $3.3(4)$ & $4.8(2)$ & $45.3(2)$ & $0.0(0)$ \\
$\mathrm{C}$ & 2017 & 7 & $1.0(10)$ & $21.5(6)$ & $31.3(2)$ & $19.6(5)$ & $17.2(6)$ & $1.5(3)$ & $97.5(1)$ & $0.0(0)$ \\
$\mathrm{C}$ & 2018 & 9 & $6.9(10)$ & $7.8(5)$ & $28.2(5)$ & $26.6(5)$ & $19.3(5)$ & $13.1(4)$ & $90.0(1)$ & $0.5(1)$ \\
$\mathrm{C}$ & 2019 & 7 & $15.85(13)$ & $1.7(5)$ & $13.25(8)$ & $3.33(6)$ & $17.75(6)$ & $12.12(4)$ & $90(1)$ & $0.0(0)$
\end{tabular}

The sedimentation differed between the different salt marsh zones, where the low and high marsh had a higher sedimentation compared to the pioneer zone and bare mudflat. With linear models the relationships between vegetation cover, vegetation height, elevation and sedimentation were tested. Both vegetation cover and vegetation height did not have a significant relationship with sedimentation (Figure 4-27A \& B), vegetation cover: $\mathrm{t}$-value ${ }_{149}=0.58, \mathrm{p}$-value $=0.55$; vegetation height: $\mathrm{t}$-value ${ }_{149}=$ $1.02, p$-value $=0.31$. However, at $P Q s$ with a vegetation height above $60 \mathrm{~cm}$, almost no erosion occurred (Figure 4-27B). This could be because vegetation height is correlated to elevation, which was significantly related to sedimentation (Figure $4-27 \mathrm{C}$, $\mathrm{t}$-value ${ }_{146}=2.10, \mathrm{p}$-value $=0.037$ ). The correlation between elevation and sedimentation was only significant for the Mud Motor site, the control site had more variation and less PQs. 
A

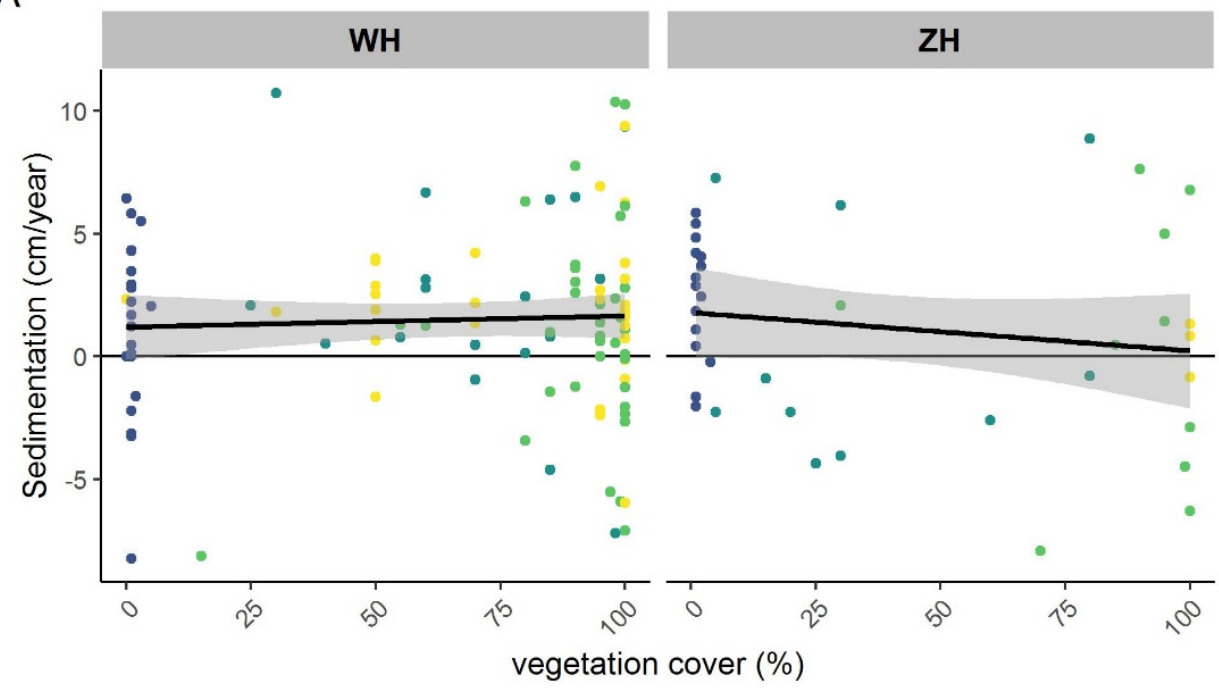

B

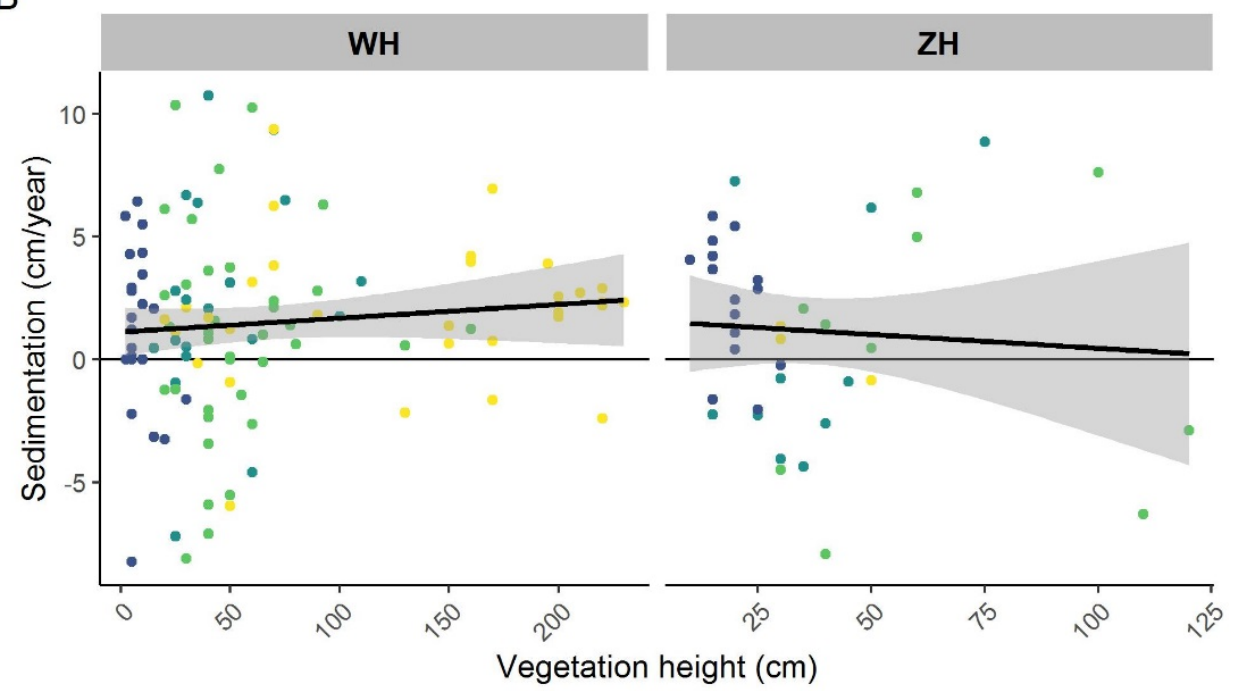

C

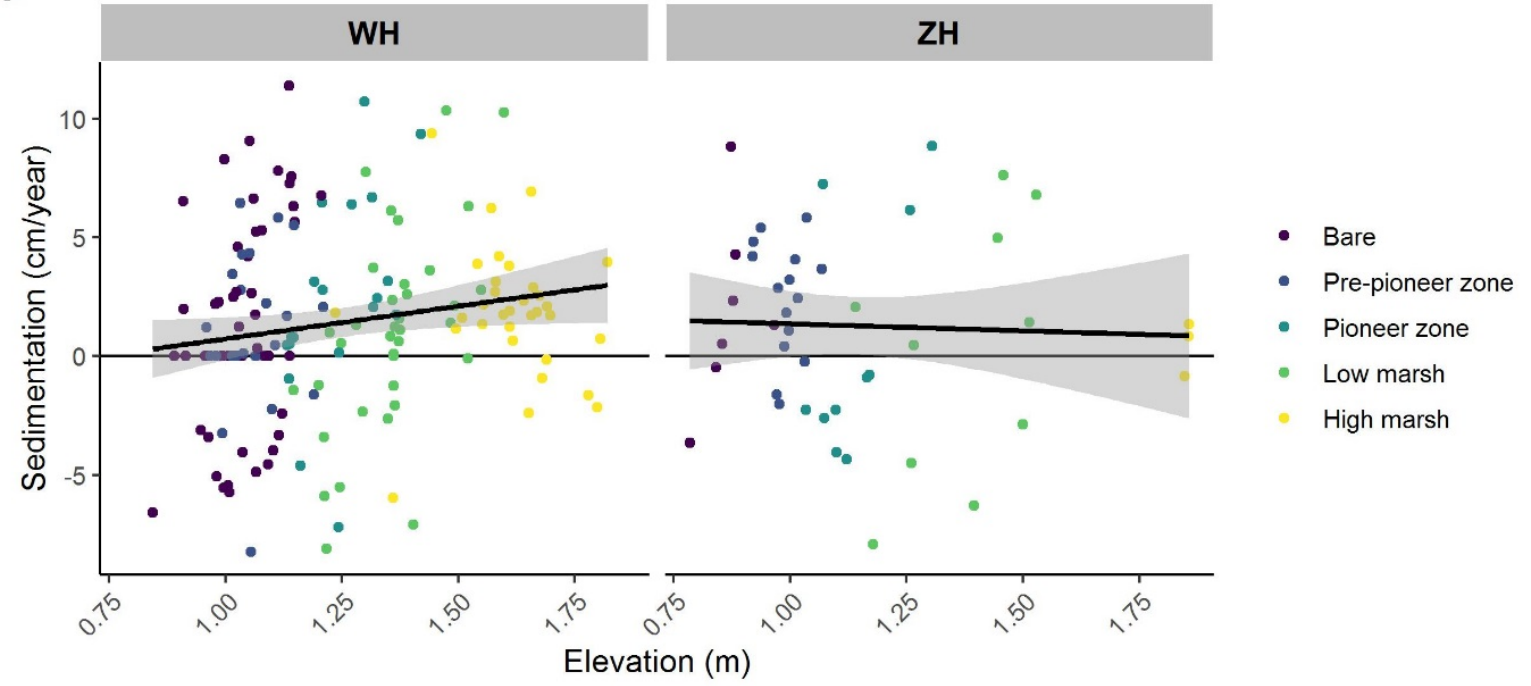

Figure 4-27. The relationship between sedimentation rate (cm/year) and A) vegetation cover (\%), B) vegetation height $(\mathrm{cm})$, and $\mathrm{C}$ ) Elevation $(\mathrm{m})$. The colours indicate the different vegetation zones. All years are included in these graphs. WH is Mud Motor Site, ZH is Control Site. 


\subsubsection{Establishment of pioneer species on the salt marsh edge}

For lateral marsh expansion, pioneer plants need to establish in the highly dynamic salt marsh-intertidal flat transition zone. As part of the NWO-TTW project various experiments were carried out to study the processes that determine establishment.

In small-scale lab experiments, oligochaete bioturbation toppled freshly sprouted Salicornia spp. seedlings and the burrowing of the oligochaete worms disturbed effective rooting (Van Regteren et al. 2017). These effects were not so strong as to cause a mutual exclusion, as shown for cordgrass (Spartina anglica) and the polychaete A. maritima (Wesenbeeck et al 2008). In the field, the highest density of oligochaetes was found in the pioneer zone (Van Regteren et al. 2019 in prep.). The pioneer zone had both the successful establishment of multiple salt marsh pioneers and the highest number of bioturbating benthos. Thus, meiofaunal bioturbation may locally inhibit the establishment of Salicornia spp. seedlings, but on a marsh scale its impact does not seem to be substantial at the Mud Motor location.

Retained seeds that are incorporated in the soil from the surface sediment become part of a seed bank. In a seed bank, germination is delayed until conditions are appropriate. When there is a deficiency of newly dispersed seeds, vegetation establishment becomes dependent on a seed bank. S. anglica and S. procumbens are the main pioneer species able to colonize the transition zone. For Salicornia spp. a natural seed bank was observed at a depth of between 4 and $9 \mathrm{~cm}$ below the surface (Van Regteren et al. 2019 in review-a). However, for S. anglica, a seed bank was absent from both the transition zone and the inner marsh. From the two main pioneer species found, $S$. anglica is better equipped than Salicornia spp. to handle sediment deposition. When sedimentation surpasses the species dependent burial depth limit, vegetation establishment will be inhibited (Huiskes et al 1985, Zhu et al 2014). Consequentially, areas with high sediment accretion rates may have reduced establishment of vegetation from seeds. Additionally, bioturbation can transport seeds below their maximum burial depth for germination and establishment (Van Regteren et al. 2019 in review-a). Additionally, freshly sprouted seedlings suffer from sedimentation as they get buried entirely (Van Regteren et al. 2019 in review-b). Other studies have shown that vegetation may cope with sedimentation as long as the growth rate outpaces sedimentation rate (Cao et al. 2018, Langlois et al. 2003). Salicornia spp. seedlings are relatively small in the initial stages and therefore may be less resilient to sedimentation in the establishment period than for example $S$. anglica.

It was also studied how dispersal timing affected seed retention and how this may influence initial vegetation establishment in the transition zone. Retention of seeds was a key factor that limited vegetation establishment in the transition zone. Seeds that were manually dispersed in December were not retained in the transition zone whereas seeds manually dispersed after winter (in March) were retained in the transition zone (Van Regteren et al. 2019 in review-a). The natural abundance of viable pioneer seeds was low in the transition zone during the vegetation establishment period (spring). This indicated that, although a seed source was in close proximity, seeds were not retained in the area where salt marsh expansion should occur. Sediment erosion after seed dispersal will strongly reduce the availability of viable seeds. The potential growth of the marsh was not limited by windows of opportunity for vegetation establishment but by the absence of seeds. This was confirmed by the sampling of the salt marsh to intertidal flat gradient. The transition zone contained very few seeds in the period when vegetation establishment should occur from seeds (Van Regteren et al. 2019 in prep.).

Establishment of pioneer vegetation is dependent on multiple abiotic factors, such as elevation and inundation regime, and a window of opportunity (Wiehe 1935; Balke et al. 2014; Hu, Van Belzen, et al. 2015). Experimental seed-additions at both Westhoek and Zwarte Haan has shown that vegetation establishment opportunities have occurred in multiple years in the transition zone. Burial, through sediment deposition or bioturbation, and erosion of seeds may both limit seed availability for vegetation establishment. 


\section{Discussion}

\subsection{Sediment dynamics}

The multi-annual surface-elevation change was determined with Sedimentation-Erosion Bars (SEBs). Results of the measurements showed relatively large changes in surface elevation. Layers of freshly deposited soft mud with a thickness of up to $10 \mathrm{~cm}$ were deposited in some locations in the salt marsh over a two- or three-month period during summer, though they disappeared just as fast during winter. During the first winter with Mud Motor nourishments, sedimentation at the Mud Motor site was similar to the control site. During the second winter with Mud Motor disposal, sedimentation at the Mud Motor site was much larger than at the control site. However, the disposed volume of dredged sediments was much smaller in the second winter compared to the first winter. Therefore, a direct link between the disposed volume and the sedimentation at the study site cannot be made. An overall effect of the Mud Motor on extra sedimentation could hence not be confirmed. Within the Mud Motor site the spatial variability in sedimentation was substantial. Larger sediment dynamics (erosion as well as accretion) was found in the southern transects closer to the Mud Motor disposal location compared to the northern transects, the latter having a higher bed elevation and a more wave-sheltered location. Generally there was a seasonal variability in which sedimentation occurred during winter and erosion and/or consolidation during the summer (Allison et al. 1995). During winter sedimentation mainly occurred through the deposition of a soft mud layer of $\sim 10 \mathrm{~cm}$ thickness. The soft mud subsequently disappears by compaction (consolidation) and/or erosion. A number of successive warm days without inundation will dry the soft mud and therefore the mud becomes part of the consolidated bed. On the other hand, when inundated the soft mud layer will often be eroded by waves and tidal currents before it can consolidate. Our two- or three-monthly measurements could not differentiate between the processes of erosion and compaction, but did reveal large variations in bed height.

Short-time surface elevation changes were determined with Surface Elevation Dynamics (SED) sensors close to the dike (i.e. within $100 \mathrm{~m}$ from the dike) at the tidal flat. Magnitudes of the bed level changes are in agreement with the SEB measurements and show rather large and fast bed level variations with sedimentation and erosion events of up to $10 \mathrm{~cm}$ on a time scale of days. These sudden bed level changes coincide with wind events, with SW winds generally leading to accretion and NE winds to erosion (and absence of wind to a stable bed). This mechanism is most distinct in the hollows (channels) of the hummock/hollow pattern at the bare mudflat. The hollows fill up with soft mud during these calmer periods, however, abrupt erosion is observed when there is a relatively large wind event (i.e. large water level set-up). The SED's suggest therefore that the timescales for bed level changes (and soft mud changes) up to $10 \mathrm{~cm}$ are days to weeks, providing more detailed information on timescales than the SEB's discussed above (with an interval of 2 to 3 months). In between periods with abrupt changes, the changes in bed level height seems to follow the spring-neap cycle. An increase in sedimentation rates in relation with disposed Mud Motor volumes could not be established from the SED's.

From both the LiDAR data as the SEB data volume changes of the bed level have been calculated for the LiDAR measurement intervals, Table 5-1. The LiDAR has a complete coverage of the mudflat area, but the downside is that the changes in bed height are within the measurement error of LiDAR. The SEB measurements have a high accuracy of $1.5 \mathrm{~mm}$, but the downside is that this accuracy is only reached in a small number of SEB stations. Overall, both data sets show reasonable agreement, with an increase in bed volume between February and September 2017 and a rather large decrease between September 2017 and Augustus 2018. An effect of the Mud Motor supply on bed volumes could not be established from the LiDAR. 
Table 5-1 Total increase/decrease in sediment volume for the mudflats $\left(m^{3}\right)$, comparison of SEB-data and LiDAR data.

\begin{tabular}{l|l|l} 
Period & $\begin{array}{l}\text { Total increase/decrease in sediment } \\
\text { volume SEB-data }\left(\mathrm{m}^{3}\right)\end{array}$ & $\begin{array}{l}\text { Total increase/decrease in sediment } \\
\text { volume LiDAR-data }\left(\mathrm{m}^{3}\right)\end{array}$ \\
\hline Feb 2017 - Sep 2017 & 14,163 & 27,000 \\
Sep 2017 - Aug 2018 & $-47,685$ & $-43,000$ \\
Feb 2017 - Aug 2018 & $-23,641$ & $-2,300$
\end{tabular}

The LiDAR measurements revealed that the channel pattern of hummocks and hollows is not a seasonal effect. The underlying patterns seem to be rather persistent and only their visibility is governed by the infilling of soft mud. They only seem to be affected by processes on a shorter timescale (e.g. extreme hydrodynamic events such as wind and wave setup) but aren't. Moreover, the persistence of the patterns suggests a longer timescale for their development than observations from the measurements with the SEBs and SEDs. The most distinct channel patterns are observed in the areas with a bed level height between 0.7 and $1 \mathrm{~m}+\mathrm{NAP}$. In the Eastern Scheldt such patterns are seasonally observed and caused by algae activity (Weerman et al. 2012). At the experimental location microphytobenthos (diatoms and cyanobacteria) could not be identified as a driver of the pattern.

A strong effect of wind on residual flow and sediment concentration was observed, especially on the shallow intertidal flats. The observation that the sediment dynamics in the Mud Motor area are dominated by wind-driven residual current transporting a given mass of sediment in the landward or seaward direction, has important implications for the functioning of the Mud Motor:

- Sediment does not need to be transported directly from the Mud Motor site to the Koehoal mudflat. It may be transported to the North East (NE), temporarily deposited on the Terschellinger Wad, and subsequently be transported to the Koehoal mudflat during a NE wind. This has a positive effect on the functioning of the Mud Motor.

- There appears to be an abundance of sediment, indicated by the very high sediment concentration (typical peaks of $1 \mathrm{to} 10 \mathrm{~g} / \mathrm{l}$ ) and the strong influence of wind direction on sediment fluxes. Sedimentation rates are therefore not supply-limited (as may in many other estuarine systems), but limited by other factors. Increasing sediment supply may not be very efficient when sedimentation is not supply-limited. This has a negative effect on the functioning of the Mud Motor.

- The large sediment availability suggests that the main limitation for accretion is the right condition at which sediment may deposit and consolidate. Sediment may be deposited for weeks, but still be easily eroded under fairly moderate hydrodynamic forcing. This also has a negative effect on the functioning of the Mud Motor. Conditions for more permanent deposition may be the right sequence of suitable wind conditions or governed by consolidation and/or vegetation development.

\subsection{Vegetation dynamics}

The salt marsh at the Mud Motor site has expanded significantly since 1996, however this expansion is not linear and is most likely related to weather conditions and sediment dynamics. The expansion was the largest in the years between 1992 and 2005. This time period has been found to have lower storm intensity and frequency and higher precipitation (van Puijenbroek et al. 2017), which have been found to be beneficial conditions for salt marsh expansion (McGraw \& Ungar 1981; Carter \& Ungar 2003). Also, the bed has been accreting over the last century, and only since the early 1990 s been high enough for vegetation establishment in combination with correct windows of opportunity. As indicated by the location of the mean high water line, there is potential for further vegetation expansion (Balke et al. 2016). The goal of the Mud Motor was to increase the vertical accretion and lateral expansion of the salt marsh by increasing the sediment supply. During the first Mud Motor supply period (September 2016 August 2017), the salt marsh showed vertical sediment accretion, however the salt marsh area reduced in size due to the retreat of the pioneer zone. In the second Mud Motor supply period (September 2017 
- August 2018), the salt marsh showed vertical sediment erosion, but lateral vegetation expansion. Moreover, the seaward extent of the marsh edge is restricted by two interacting factors: inundation time and bed level change (Willemsen et al., 2018). Since it could neither be found that short-term bed level change was affected by the Mud Motor, nor that the long-term bed level increased, a large seaward expansion of the marsh within the measurement period was unlikely.

Although vertical accretion is important for the salt marsh to keep up with sea-level rise (Kirwan \& Megonigal 2013), the overall area of the salt marsh is determined by lateral growth through successful establishment of pioneer plants on the bare intertidal flat. In the years that were studied, both seaward growth and landward retreat of the marsh edge occurred. Since the most common pioneer species is the annual species Salicornia spp., yearly weather conditions and sediment dynamics largely determine its cover (Huiskes et al. 1985). Factors that determine the germination and growth of pioneer plants are temperature, precipitation, sediment dynamics and inundation frequency (van Regteren et al.; Carter \& Ungar 2003; Balke et al. 2016). Temperature and precipitation affect survival and growth of pioneer species, especially once they germinated. Sediment deposition or erosion can bury or erode seeds and small plants (Van Regteren et al. in review). From August 2016 to August 2017 (with $300.000 \mathrm{~m}^{3}$ Mud Motor supply), the salt marsh area decreased with 3.5 ha, but the sediment deposition was overall quite high $(4 \mathrm{~cm})$ and especially high on the mudflat $(5 \mathrm{~cm})$. The seeds or seedlings may have been buried and therefore incorporated in the seed bank or not survived. The sedimentation was quite dynamic, with high volumes of (soft mud) sediment deposited and later eroded away, indicating that higher sediment dynamics is detrimental for vegetation expansion.

The cover of the main pioneer species (S. europaea and S. procumbens) in our permanent quadrants showed an increase in the same year the salt marsh area decreased. This is not what one would expect, however, most likely is that $S$. europaea established at higher elevation on the salt marsh. In the low marsh the biannual $A$. tripolium decreased in cover, which could have created space for the establishment of $S$. europaea. We found a positive correlation between elevation and sedimentation in the Mud Motor site. This suggests that sediment or soft mud that is deposited at locations higher up the marsh is less easily eroded or may have more appropriate conditions for sediment consolidation.

The Mud Motor was intended to stimulate salt marsh accretion in a period of months, which was expected to lead to salt marsh expansion in a period of years. During the time that sediment was actively supplied, there was both salt marsh retreat and expansion. The horizontal retreat occurred when the salt marsh was vertically accreting, and the salt marsh expansion occurred when there was erosion of the marsh platform. This is probably linked to the availability of seeds for vegetation establishment (Van Regteren et al. 2019 in review-a). Furthermore, our control site at Zwarte Haan showed similar sedimentation patterns, and the bed level was even more stable. The changes in salt marsh area are unknown for Zwarte Haan, but the permanent quadrants show similar changes compared to the Mud Motor site. This indicates that Zwarte Haan may have not been an appropriate control site. Our original assumption that vertical salt marsh and mudflat accretion results in horizontal salt marsh expansion cannot be confirmed by our results. Salt marsh expansion is dependent on multiple factors that result in a window of opportunity needed for the seeds to germinate and grow (Wiehe 1935; Balke et al. 2014; $\mathrm{Hu}$, Van Belzen, et al. 2015). The window of opportunity is not only affected by the sediment dynamics, but also by inundation frequency, precipitation, temperature and seed availability. Seed additions in the transition zone have shown that the appropriate windows of opportunity for vegetation establishment were occurring (Van Regteren et al. 2019 in review-a \& -b), although vegetation expansion did not. It is therefore plausible that seed availability, instead of sediment, was the main limiting factor for marsh expansion during the Mud Motor project. 


\section{Conclusions}

The aim of the monitoring programme was to assess the effect of the Mud Motor on the dynamics of adjacent tidal flats and salt marshes at the study site Koehoal. i.e. whether the increased sediment supply due to the Mud Motor results in sedimentation and expansion of the local salt marshes. The dynamics of the intertidal area at Koehoal and a control site were monitored to assess the possible effect of a Mud Motor.

Over the last century, sedimentation rates over the intertidal area gradually declined, with only little sedimentation in recent years. The bed level in the area of interest decreased from relatively elevated at the eastern side towards more low-lying at the western side. Consequently, salt marsh vegetation is established at the eastern side, whereas bed levels on the western side are too low for vegetation establishment. Moreover, vegetation establishment at the current location of the salt marsh is enhanced by a landward concavity in the coast/dike, locally sheltering the intertidal area. The bed level, sheltered location and orientation from the dominant wind direction and adjacent channel, contribute to current salt marsh extent.

To investigate the fate of disposed sediment prior to the actual dredge spoil release, a tracer experiment was executed. A large amount of tracer material released at the disposal site was indeed retrieved at the intertidal area near Koehoal. However, despite the close proximity of the release location, it took several weeks before most of the released tracer was deposited on the Koehoal mudflats. This is probably the result of meteorological effects: observations of flow velocity, suspended sediments and water levels revealed that mud transport is strongly governed by the wind. Sediment disposed at the Mud Motor site may therefore be initially transported NE of the study site (following the Kimstergat channel onto a tidal divide), and be remobilised later and transported to the Koehoal intertidal flats.

Settling and erosion of sediments is further complicated by soft mud formation. SEBs deployed in the winter season revealed the presence of a soft mud layer of approximately $10 \mathrm{~cm}$ thick, whereas slightly higher bed levels without soft mud are typically observed in summer. A possible explanation for this seasonal difference can be the compaction of soft mud and/or more favourable conditions for settlement and consolidation of sediments in summer. On the shorter timescale (days to weeks), the magnitude of bed level variations was also found to reach $10 \mathrm{~cm}$. Observations with SEDs showed that bed level dynamics were larger in winter than in summer, making it likely that these variations are also caused by soft mud. Local fieldwork indicated that more soft mud was present in the hollows/gullies at the tidal flat surface. The bed level variations were found to be larger in these hollows/gullies than at the higher elevated hummocks, indicating the co-existence (in addition to the seasonal timescale) of a smaller timescale for soft mud dynamics. LiDAR measurements revealed that the location of the small gullies is reasonably constant. The network of gullies and hollows can therefore serve as an accommodation space for soft mud.

More landward from the tidal flat, at the lower and higher salt marsh, sedimentation and erosion can hinder vegetation establishment. However, gradual sedimentation rates can contribute to vegetation growth in the pioneer zone. Both measurements with LiDAR and SEBs show erosion at the tidal flat between August 2017 and August 2018, and hence no effect of the Mud Motor was observed that last beyond this period. Moreover, the Mud Motor site and the control site near Zwarte Haan show similar erosion/sedimentation patterns, implying that the effect of the Mud Motor is absent or spread out over a larger area, including the control site. Despite the vertical erosion of the tidal flat and the salt marsh in the period August 2017 - August 2018, the salt marsh has expanded in lateral direction. The surface sediment erosion may have brought pioneer seeds back to the surface. Salicornia spp. seeds are not able to establish successfully when buried below $1 \mathrm{~cm}$ deep (Huiskes et al 1985). Additionally, too large sedimentation rates may prevent salt marsh establishment due to burial of seeds and smothering of the seedlings. In Aug 2016 - Aug 2017 for example, sedimentation has occurred, and the salt marsh cover is decreasing strongly. Additionally, the availability of seeds in the transition zone (where expansion was 
expected) was very low, in May 2016. Experimental seed-additions have confirmed that key boundary conditions such as elevation and inundation regime were appropriate for vegetation establishment and thus marsh expansion at the experimental location in multiple years. Thus, the main limitation for vegetation establishment in the transition zone was the availability of viable pioneer seeds.

Despite the sedimentation observed at the salt marsh and tidal flat during sediment disposal at the Mud Motor Site, i.e. when the Mud Motor was active, natural dynamics were too large to distinguish a causal contribution of the Mud Motor to sedimentation. However, neither it can be determined that the Mud Motor did not enhance salt marsh expansion. The Mud Motor pilot project shows that sediment was transported from the disposal site to the intertidal zone. Transport towards the tidal flat and salt marsh should be followed by the opportunity for sediment to settle and compact for the long-term (i.e. years to decades). A contribution of the current Mud Motor pilot to the latter was not proven.

Finally, for salt marsh vegetation to establish in the transition zone, viable pioneer seeds should be available and natural dynamics of both the bed and hydrodynamics should be little during the growing season. The Mud Motor might support marsh expansion by increasing the bed level, eventually leading to salt marsh expansion if vegetation establishes in the transition zone. So, the key for a Mud Motor to be effective is sediment transport in the right direction, the opportunity for sediment to settle and consolidate, retention of seeds and minor and gradual natural dynamics in the growing season for successful vegetation establishment. The Mud Motor itself will only influence the first requirement (sediment transport) and will therefore be most effective when the sediment transport is a limiting factor for vegetation establishment. 


\section{Acknowledgements}

We acknowledge a great team of people that helped during field measurements, often in tough conditions: Amrit Cado van der Lelij, Jasper Dijkstra, Jill Hanssen, Maria Ibanez, Miguel de Lucas Pardo, Reinier Schrijvershof, Lodewijk de Vet. We thank the EcoShape BwN team members Alma de Groot, Theo Gerkema, Janine Nauw, Jelmer Cleveringa, Bart Grasmeijer, Petra Dankers, Thomas Vijverberg, Femkje Sierdsma, Nathanael Geleynse, Filip Schuurman, Sytske Stuij, Marcel van den Heuvel, Lucie Evaux, Wout van Dijk, Klaas Laansma, Jeltje van Dijk, Erik van Slobbe and Jasper Leuven. We acknowledge the MT EcoShape Henk Nieboer, Erik van Eekelen and Luca Sittoni, and their supporting staff Carrie de Wilde, Jennefer Smits and Jolanda de Ruyter. We thank Chris Bakker from It Fryske Gea for his expert advice. We thank Arjen Bosch for his process guidance. We thank John Walta and Reiner de Vries of the Municipality of Harlingen for their support. We thank Jon Marsh of Environmental Tracing Systems Ltd. for the tracer experiment. We thank De Boer dredging, and especially Jan-Teije Stellema, for carrying out the required dredging works and disposal at the Mud Motor location. We acknowledge Shore monitoring collecting bed samples, installing frames and for flying their LiDAR drone and we thank SkySurvey for making drone photos. We thank the supporting staff of Deltares, Marcel Busink and Marcel Grootenboer, and supporting staff of WMR, Cor Sonneveldt, André Meijboom, Simon de Vries and Piet-Wim van Leeuwen.

This work was financially supported by the Dutch Waddenfonds under grant number WF221847, It Fryske Gea, Municipality of Harlingen, Technology Foundation STW, EcoShape and partners, the Wageningen University Knowledge Base programme project KB-36-003-010 and Deltares Strategic Funding of the theme 'Ecosystems and Environmental Quality'. 


\section{References}

Aarninkhof, S.G.J., Allewijn, R., Kleij, A.M., Stive, M.J.F., \& Baptist, M.J. 2012. Sustainable development of land reclamations and shorelines full scale experiments as a driver for public - private innovations. In Virtue, Venture and Vision in the Coastal Zone: CEDA Dredging Days, pp. 112.

Allen, J.R.L. 1989. Evolution of salt-marsh cliffs in muddy and sandy systems: A qualitative comparison of British West-Coast estuaries. Earth Surface Processes and Landforms 14: 85-92.

Allison, M.A., Nittrouer, C.A., \& Kineke, G.C. 1995. Seasonal sediment storage on mudflats adjacent to the Amazon River. Marine Geology 125: 303-328.

Balke, T., Herman, P.M.J., \& Bouma, T.J. 2014. Critical transitions in disturbance-driven ecosystems: Identifying windows of opportunity for recovery. Journal of Ecology 102: 700-708.

Balke, T., Stock, M., Jensen, K., Bouma, T.J., \& Kleyer, M. 2016. A global analysis of the seaward salt marsh extent: The importance of tidal range. Water Resources Research 52: 3775-3786.

Baptist, M.J., Van Eekelen, E.E., Dankers, P.J.T., Grasmeijer, B., Van Kessel, T., \& Van Maren, D.S. 2017. Working with Nature in Wadden Sea Ports. In Coasts \& Ports 2017 Conference - Cairns, 21-23 June 2017,

Baptist, M.J., Gerkema, T., Van Prooijen, B.C., Van Maren, D.S., Van Regteren, M., Colosimo, I., Vroom, J., Van Kessel, T., Grasmeijer, B., Willemsen, P., De Groot, A. V, Cleveringa, J., Van Eekelen, E.E., Schuurman, F., \& De Lange, H.J. 2019. Beneficial use of dredged sediment to enhance salt marsh development applying a Mud Motor. Ecological Engineering 127: 312-323.

Brandon, D.L., \& Price, R.A. 2007. Summary of Available Guidance and Best Practices for Determining Suitability of Dredged Material for Beneficial Uses. Vicksburg, MS, U.S. Army Engineer Research and Development Center, Report ERDC/EL TR-07-27.

Cahoon, D.R., \& Cowan, J.H. 1988. Environmental impacts and regulatory policy implications of spray disposal of dredged material in louisiana wetlands. Coastal Management 16: 341-362.

Cao, H., Zhu, Z., Balke, T., Zhang, L., \& Bouma, T.J. (2018). Effects of sediment disturbance regimes on Spartina seedling establishment: Implications for salt marsh creation and restoration. Limnology and Oceanography 63(2): 647-659.

Carter, C.T., \& Ungar, I.A. 2003. Germination response of dimorphic seeds of two halophyte species to environmentally controlled and natural conditions. Canadian Journal of Botany 81: 918-926.

Colosimo, I., De Vet, P.L.M., Van Maren, D.S., Reniers, A.J.H.M., Winterwerp, J.C., \& Van Prooijen, B.C. (in review). Tide-Wind Interaction Effects on the Intertidal Flat Sediment Transport. Journal of Geophysical Research

Delaune, R.. D., Pezeshki, S.R., Pardue, J.H., Whitcomb, J.H., \& Patrick, W.H. 1990. Some influences of sediment addition to a deteriorating salt marsh in the Mississippi River deltaic plain: a pilot study. Journal of Coastal Research 6: 181-188.

Dijkema, K.S. 1983. The salt-marsh vegetation of the mainland coast, estuaries and Halligen. In Dijkema, K.S. \& Wolff, W.J. (eds.), Flora and vegetation of the Wadden Sea island and coastal areas, pp. 185-220. Balkema, Rotterdam. 
Dijkema, K.S., Beeftink, W.G., Doody, J.P., Gehu, J.M., Heydemann, B., \& Rivas Martinez, S. 1984. Salt marshes in Europe. Strasbourg, Council of Europe, Nature and Environment Series 30.

Dijkema, K.S., Bossinade, J.H., Bouwsema, P., \& De Glopper, R.J. 1990. Salt marshes in the Netherlands Wadden Sea: rising high-tide levels and accretion enhancement. In Beukema, J.J. et al. (ed.), Expected Effects of Climate Change on Marine Coastal Ecosystems, pp. 173-188. Kluwer Academic Publishers.

Van Eekelen, E., Baptist, M.J., Dankers, P.J.T., Grasmeijer, B., Van Kessel, T., \& Van Maren, D.S. 2016. Muddy Waters and the Wadden Sea Harbours. In WODCON XXI Proceedings of the Twenty-First World Dredging Congress, WODCON XXI, Miami, FLorida USA, June 13-17, 2016.,

Ford, M.A., Cahoon, D.R., \& Lynch, J.C. 1999. Restoring marsh elevation in a rapidly subsiding salt marsh by thin-layer deposition of dredged material. Ecological Engineering 12: 189-205.

Gatto, V.M., Van Prooijen, B.C. \& Wang, Z.B. 2017. Net sediment transport in tidal basins: quantifying the tidal barotropic mechanisms in a unified framework. Ocean Dynamics, 67(11), 1385-1406.

Graham, S.A., \& Mendelssohn, I.A. 2013. Functional assessment of differential sediment slurry applications in a deteriorating brackish marsh. Ecological Engineering 51: 264-274.

Grasmeijer, B. 2016. Uitvoeringsplan slibmotor Kimstergat. Zwolle, Arcadis rapport C03041.001971 (in Dutch).

Gulden, F.J.H. 2018. UAV LiDAR Metingen Slibmotor - Veldrapportage T3 20180821. Shore Monitoring \& Research BV.

Hu, Z., Van Belzen, J., Van Der Wal, D., Balke, T., Wang, Z.B., Stive, M., \& Bouma, T.J. 2015. Windows of opportunity for salt marsh vegetation establishment on bare tidal flats: The importance of temporal and spatial variability in hydrodynamic forcing. Journal of Geophysical Research G: Biogeosciences 120: 1450-1469.

Hu, Z., Lenting, W., van der Wal, D., \& Bouma, T.J. 2015. Continuous monitoring bed-level dynamics on an intertidal flat: Introducing novel, stand-alone high-resolution SED-sensors. Geomorphology 245: 223-230.

Huiskes, A.H.L., Stienstra, A.W., Koutstaal, B.P., Markusse, M.M., \& Van Soelen, J. 1985. Germination ecology of Salicornia dolichosachya and Salicornia brachystachya. Plant Biology 34: 369-380.

IADC. 2015. Dredging in figures 2015. The Hague, International Association of Dredging Companies.

De Jong, D.J., Dijkema, K.S., Bossinade, J.H., \& Janssen, J.A.M. 1998. SALT 97: Classificatieprogramma voor kweldervegetaties (cd-rom).

Kirwan, M.L., \& Megonigal, J.P. 2013. Tidal wetland stability in the face of human impacts and sea-level rise. Nature 504: 53-60.

Langlois, E., Bonis, A., \& Bouzillé, J.B. 2003. Sediment and plant dynamics in saltmarshes pioneer zone: Puccinellia maritima as a key species? Estuarine, Coastal and Shelf Science 56: 239249.

Lawrence, P.J., Smith, G.R., Sullivan, M.J.P., \& Mossman, H.L. 2018. Restored saltmarshes lack the topographic diversity found in natural habitat. Ecological Engineering 115: 58-66.

Leonardi, N., Carnacina, I., Donatelli, C., Ganju, N.K., Plater, A.J., Schuerch, M., \& Temmerman, S. 2018. Dynamic interactions between coastal storms and salt marshes: A review. Geomorphology 301: 92-107. 
Londo, G. 1976. The decimal scale for releves of permanent quadrats. Vegetatio 33: 61-64.

McGraw, D.C., \& Ungar, I.A. 1981. Growth and Survival of the Halophyte Salicornia Europaera L. under Saline Field Conditions. The Ohio Journal of Science 81: 109-113.

Meade, R.H., \& Moody, J.A. 2010. Causes for the decline of suspended-sediment discharge in the Mississippi River system, 1940-2007. Hydrol. Process. 24: 35-49.

Mendelssohn, I.A., \& Kuhn, N.L. 2003. Sediment subsidy: Effects on soil-plant responses in a rapidly submerging coastal salt marsh. Ecological Engineering 21: 115-128.

National Research Council. 1985. Dredging Coastal Ports: An Assessment of the Issues. The National Academies Press, Washington, DC.

Neumeier, U., \& Amos, C.L. 2006. The influence of vegetation on turbulence and flow velocities in European salt-marshes. Sedimentology 53: 259-277.

Nolte, S., Koppenaal, E.C., Esselink, P., Dijkema, K.S., Schuerch, M., De Groot, A. V., Bakker, J.P., \& Temmerman, S. 2013. Measuring sedimentation in tidal marshes: A review on methods and their applicability in biogeomorphological studies. Journal of Coastal Conservation 17: 301-325.

PIANC. 2011. Towards a sustainable waterborne transportation industry. Brussels, PIANC EnviCom TG 2.

van Puijenbroek, M.E.B., Limpens, J., De Groot, A. V, Riksen, M.J.P.M., Gleichman, M., Slim, P.A., van Dobben, H.F., \& Berendse, F. 2017. Embryo dune development drivers: beach morphology, growing season precipitation, and storms. Earth Surface Processes and Landforms. doi: 10.1002/esp.4144

Van Regteren, M., Colosimo, I., De Vries, P., Van Puijenbroek, M.E.B., Freij, V., Baptist, M.J., \& Elschot, $\mathrm{K}$. (in review-a). Limited seed retention during winter inhibits vegetation establishment in spring, affecting lateral marsh expansion capacity. Submitted to Journal of Ecology and Evolution.

Van Regteren, M., Meesters, E.H., Baptist, M.J., De Groot, A.V., Bouma, T.J. \& Elschot, K. (in reviewb). Multiple environmental variables affect germination and mortality of a salt marsh pioneer, Salicornia procumbens. Submitted to Plant and Soil.

Van Regteren, M., Amptmeijer, D., De Groot, A.V., Baptist, M.J., \& Elschot, K. (in prep.). Where does the salt marsh begin? Field-based evidence of an abrupt transition between tidal flat and salt marsh on a gradual slope. Estuarine and Coastal Shelf Science.

Schulz, K., \& Gerkema, T. 2018. An inversion of the estuarine circulation by sluice water discharge and its impact on suspended sediment transport. Estuarine, Coastal and Shelf Science 200: 31-40.

Schwarz, C., Bouma, T.J., Zhang, L.Q., Temmerman, S., Ysebaert, T., \& Herman, P.M.J. 2015. Interactions between plant traits and sediment characteristics influencing species establishment and scale-dependent feedbacks in salt marsh ecosystems. Geomorphology 250: 298-307.

Shafer, D.J., \& Streever, W.J. 2000. A comparison of 28 natural and dredged material salt marshes in Texas with an emphasis on geomorphological variables. Wetlands Ecology and Management 8: 353-366.

Spalding, M.D., Mcivor, A.L., Beck, M.W., Koch, E.W., Möller, I., Reed, D.J., Rubinoff, P., Spencer, T., Tolhurst, T.J., Wamsley, T. V., van Wesenbeeck, B.K., Wolanski, E., \& Woodroffe, C.D. 2014. Coastal ecosystems: A critical element of risk reduction. Conservation Letters 7: 293-301.

Stive, M.J., De Schipper, M.A., Luijendijk, A.P., Aarninkhof, S.G., Van Gelder-Maas, C., Van Thiel de Vries, J.S., De Vries, S., Henriquez, M., Marx, S., \& Ranasinghe, R. 2013. A new alternative to 
saving our beaches from sea- level rise: The sand engine. Journal of Coastal Research 29: 1001-1008.

Straaten, L.V. van \& Kuenen, P.H. 1957. Accumulation of fine grained sediments in the Dutch Wadden Sea. Geologie en Mijnbouw 19: 329-354.

Streever, W.J. 2000. Spartina alterniflora marshes on dredged material: A critical review of the ongoing debate over success. Wetlands Ecology and Management 8: 295-316.

Temmerman, S., Meire, P., Bouma, T.J., Herman, P.M., Ysebaert, T., \& De Vriend, H.J. 2013. Ecosystem-based coastal defence in the face of global change. Nature 504: 79-83.

Tong, C., Baustian, J.J., Graham, S.A., \& Mendelssohn, I.A. 2013. Salt marsh restoration with sedimentslurry application: Effects on benthic macroinvertebrates and associated soil-plant variables. Ecological Engineering 51: 151-160.

U.S. Army Corps of Engineers. 1987. Beneficial Uses of Dredged Material. Washington, DC, USACE Engineer Manual No 1110-2-5026.

Vandenbruwaene, W., Schwarz, C., Bouma, T.J., Meire, P., \& Temmerman, S. 2015. Landscape-scale flow patterns over a vegetated tidal marsh and an unvegetated tidal flat: Implications for the landform properties of the intertidal floodplain. Geomorphology 231: 40-52.

Vroom, J. 2015. Modelresultaten slibverspreiding t.b.v. slibmotor Koehol. Delft, Deltares memo 1209751-000- ZKS-0001 (in Dutch).

Vroom, J., Van Maren, D.S., Marsh, J., \& Cado van der Lelij, A. 2016. Effectiveness of the mud motor near Koehool; Results and interpretion of a tracer study. Delft, Deltares report 1209751-004.

de Weger, R.Ph. 2017. UAV LiDAR Metingen Slibmotor - Veldrapportage T2 20170823. Shore Monitoring \& Research BV.

Van Wesenbeeck, B.K., Van De Koppel, J., Herman, P.M.J., \& Bouma, T.J. 2008. Does scaledependent feedback explain spatial complexity in salt-marsh ecosystems? Oikos 117: 152-159.

Weerman, E.J., Van Belzen, J., Rietkerk, M., Temmerman, S., Kéfi, S., Herman, P.M.J. \& de Koppel, J.V. (2012). Changes in diatom patch-size distribution and degradation in a spatially selforganized intertidal mudflat ecosystem. Ecology 93(3): 608-618.

Wiehe, P.O. 1935. A Quantitative Study of the Influence of Tide Upon Populations of Salicornia Europea. The Journal of Ecology 23: 323.

Willemsen, P.W.J.M., Borsje, B.W., Hulscher, S.J.M.H., Van der Wal, D., Zhu, Z., Oteman, B., Evans, B., Möller, I., \& Bouma, T.J. 2018. Quantifying bed level dynamics at the transition of tidal flat and salt marsh: can we understand the lateral location of the marsh edge? Journal of Geophysical Research: Earth Surface 123:.

de Zeeuw, R.C. 2017. UAV LiDAR Metingen Slibmotor - Veldrapportage T1 20170206. Shore Monitoring \& Research BV.

Zhu, Z., Bouma, T.J., Ysebaert, T., Zhang, L., \& Herman, P.M. (2014). Seed arrival and persistence at the tidal mudflat: identifying key processes for pioneer seedling establishment in salt marshes. Marine Ecology Progress Series 513: 97-109. 